\title{
A History of Violence: British Colonial Policing in Ireland and the Palestine Mandate
}

Tyler Krahe

Follow this and additional works at: https://researchrepository.wvu.edu/etd

\section{Recommended Citation}

Krahe, Tyler, "A History of Violence: British Colonial Policing in Ireland and the Palestine Mandate" (2016). Graduate Theses, Dissertations, and Problem Reports. 6011.

https://researchrepository.wvu.edu/etd/6011

This Thesis is protected by copyright and/or related rights. It has been brought to you by the The Research Repository @ WVU with permission from the rights-holder(s). You are free to use this Thesis in any way that is permitted by the copyright and related rights legislation that applies to your use. For other uses you must obtain permission from the rights-holder(s) directly, unless additional rights are indicated by a Creative Commons license in the record and/ or on the work itself. This Thesis has been accepted for inclusion in WVU Graduate Theses, Dissertations, and Problem Reports collection by an authorized administrator of The Research Repository @ WVU. For more information, please contact researchrepository@mail.wvu.edu. 
A History of Violence: British Colonial Policing in Ireland and the Palestine Mandate

\author{
Tyler Krahe
}

Thesis submitted to the Eberly College at West Virginia University

in partial fulfillment of the requirements for the degree of

Master of Arts in History

Joseph Hodge, Ph.D., Chair

Katherine Aaslestad, Ph.D.

Robert Blobaum, Ph.D.

Department of History

Morgantown, West Virginia

2016

Keywords: Great Britain, Policing, Ireland, Mandate Palestine, Black and Tans, Palestine Police, Royal Irish Constabulary, British Gendarmerie, Violence, Paramilitary

Copyright 2016 Tyler Krahe 


\begin{abstract}
A History of Violence: British Colonial Policing in Ireland and the Palestine Mandate Tyler Krahe

British colonial policing dramatically evolved between 1920 and 1948. This time period represents the duration of the Anglo-Irish War, as well as British control of the Palestine Mandate. It was during the period that the security forces at work within these areas grew to combat similar nationalist populations. During the Anglo-Irish War in 1919 the security forces in Ireland found themselves unable to quell the rebellion of Irish nationalists. To supplement their inadequate numbers the Royal Irish Constabulary took on and trained large numbers of World

War I veterans who were in desperate need of work. These men came to be known as the infamous 'Black and Tans'. They quickly earned a reputation for using violent tactics when dealing with the Irish Republican Army. Following the resolution of the Anglo-Irish War, many of these men were left with few employment options until the Empire came calling again. This time they were called upon to police the newly formed mandate in Palestine. A large portion of the Royal Irish Constabulary, as well as the Black and Tans immediately signed up to forge the

British Gendarmerie in Palestine. This unit helped to keep the peace during years of heavy Jewish immigration into the Holy Land until 1926 when it was absorbed into the Palestine

Police. Many of the same men who had started their career in Ireland continued into the Gendarmerie and further into the Palestine Police until the Mandate ended in 1948. During the 1930s and 1940s the Palestine Police at first were able to effectively police the population of the Mandate, but ultimately were unsuccessful in combating the forces of Jewish nationalism and Jewish terrorism. This study is supported by primary sources including administrative reports, commissions, personal diaries, personal correspondence, oral histories and memoirs. Further, it consults a wide range of secondary literature.
\end{abstract}




\section{Table of Contents}

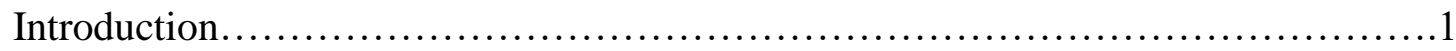

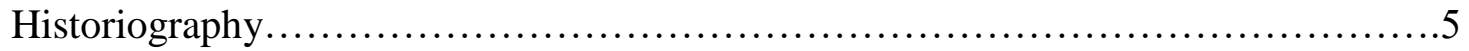

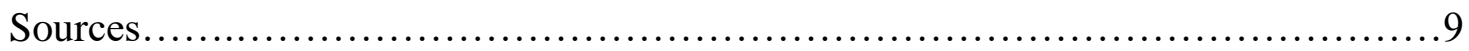

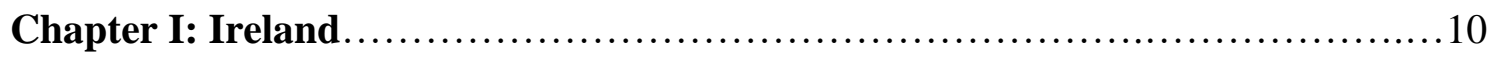

Home Rule and the Nationalist Rising ..................................11

The Easter Rising .................................................... 16

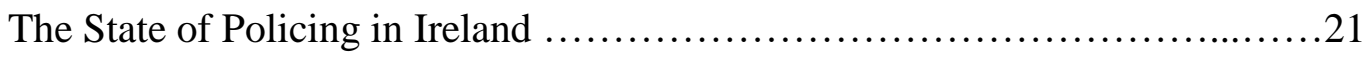

Ambush and Reprisal: Black and Tan Violence in the Anglo-Irish War.........26

Chapter II: Transition and the Holy Land ........................................ 37

The Middle East During and After the First World War.........................38

The State of Policing in Palestine ...........................................42

The British Gendarmerie and the Recruitment of the Irish Contingent ...........47

The British Gendarmerie in Palestine ......................................52

The Fall of the Gendarmerie, the Rise of the Palestine Police....................55

Chapter III: The Palestine Police: Uprising and Revolt and Reform...............64

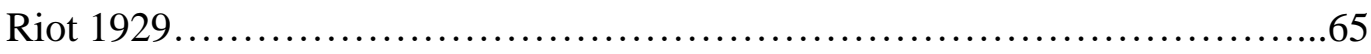

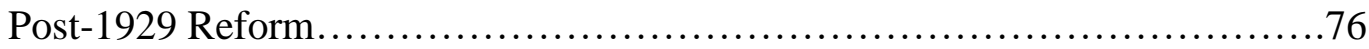

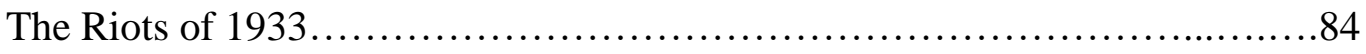

The Arab Revolt 1936-1939...................................................92

Chapter IV: War and the End of the Mandate................................... 106

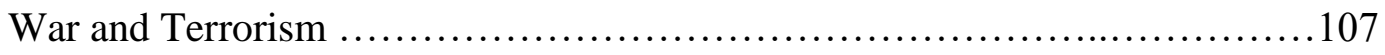

The End of Empire in Palestine.......................................... 115

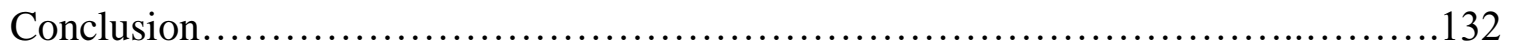

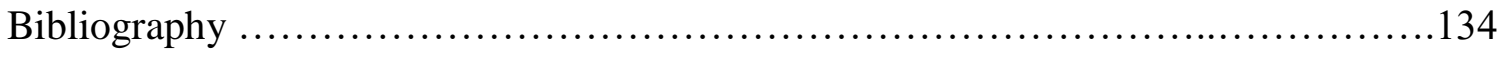




\section{Introduction}

In the twentieth century the manner in which the British Empire was policed inherently changed. Starting with the Royal Irish Constabulary in Ireland a new, more brutal form of paramilitary policing force emerged that stood in sharp contrast to the unarmed Metropolitan Police in London. Officers carried weapons and took on tasks the looked increasingly like those belonging to a military intelligence agency. The divide between traditional police and this new species grew even more dramatically during the Anglo-Irish War of the early 1920s. Facing low enrollment numbers, as well as an increasingly more violent nationalist enemy, the Royal Irish Constabulary began to take on large numbers of new recruits to supplement their ranks. Many of

these men were veterans of the First World War and in search of a job. They became members of the Auxiliary Division and the better-known, and certainly more infamous Black and Tans.

Following a brief training period that placed little emphasis on traditional police work, the units were deemed fit for duty and posted throughout Ireland. What followed was two years of constant violence between the security forces in Ireland and Irish nationalists. The nationalists attacked the British forces which they considered to be an unlawful occupying force and in return certain members of the British forces exacted violent retribution upon the nationalists.

Eventually, the British Empire was forced to cut their losses in Ireland and grant independence. This however left a number of English and Irish police officers without a job and especially for many of the Irish, without a safe home to which they could return. Fortunately for these men an opportunity presented itself to continue their policing career in the newly formed British Gendarmerie in Palestine 
The British Gendarmerie was formed in order to help police the newly formed Palestine Mandate. As Great Britain had assumed stewardship of the Mandate, a greater security force was needed to help control the boarders and keep the peace between the increasing number of Jewish immigrants and the native Arab population. Many feared that with the force being comprised almost entirely of former Black and Tan, Auxiliary, and RIC men, the brutality of their behavior in Ireland would be exported to Palestine. This however was not the case. The British Gendarmerie performed quite well and without serious incident. In fact the years of the British Gendarmerie were some of the most peaceful in the Mandate. So peaceful were these years that government spending on security was cut each successive year until in 1926 it was deemed financially necessary to disband the Gendarmerie and incorporate it into the existing Palestine Police, which had been in operation since 1920.

The Mandate remained relatively peaceful as the former Gendarmes were incorporated into the force. Training and reform was already taking place in order to make them more capable police officers skilled in detection and investigation. Despite these efforts, the force proved itself unprepared to handle the reality of religious and nationalist fervor in Palestine. The 1929 Massacre set off a decade of turmoil in which the police would continually evolve through a process of revolt and reform until the onset of World War Two. ${ }^{1}$ During and after the war the force could no longer control the increasingly violent organizations of Jewish nationalism and the British Empire was forced to release yet another one of its holdings.

It is the argument of this study that the security forces in Ireland began a trajectory of ever-evolving police tactics that were initially designed in response to violence in Ireland and

\footnotetext{
${ }^{1}$ The 1929 Massacre was a large scale disturbance that took place across several districts within the Palestine Mandate.
} 
later transitioned into the Palestine Mandate, grew to the greatest extent during the 1930s, and finally plateaued with the onset and aftermath of World War Two. The evolution of colonial policing in this context takes into account two societies with extremely complex and contentious histories. The forces of nationalism and religion were constantly at work serving to further muddy the already murky waters of understanding. In an attempt to provide clarity this work shall be divided into four chapters.

The first chapter will focus on Ireland alone. To understand how the Royal Irish Constabulary created the base for a new type of colonial policing and how that idea evolved during the Anglo-Irish War one must first consider the long and contentious history that existed between Great Britain and Ireland. As such, this chapter begins with an account of Ireland's incorporation within the imperial fold during the nineteenth century, as well as the many attempts of its people to resist that relationship. This chapter will also consider the nationalist elements that came to prominence during late nineteenth and early twentieth centuries. Finally, the introduction of the Black and Tan and other Auxiliary forces during the Anglo-Irish War will be discussed and analyzed to demonstrate the brief training men received to combat Irish nationalists.

The second chapter traces the transition of the security forces in Ireland into the British Gendarmerie in Palestine. As with Ireland, the Palestine Mandate has its own unique history and relationship with Great Britain. It is necessary to understand the conditions during World War One under which the Mandate was created and how Great Britain's involvement served to inflame religious and nationalist tensions in the territory. Also discussed is the state of policing during the establishment of the Mandate prior to the arrival of the Ireland contingent. This includes the establishment of the Palestine Police along with the expensive garrisoning of 
military troops in the region. Central to this chapter is the actual transition of the security forces into the Gendarmerie, as well as the training and experience of the men themselves. The chapter will conclude with an account of the Gendarmerie's success and the terms of its disbandment.

Chapter three demonstrates the greatest period of evolution for the police between Ireland and Palestine. The chapter begins with the new Palestine Police facing its first real test, and first failure; the 1929 Hebron Massacre. The rest of the chapter focuses largely on the period of 'riot and reform' that took place throughout the 1930s. This represents the ten years that the Palestine Police spent dealing with riots and rebellions and also the commissions and reforms that took place after each incident. Finally, this chapter follows the rise and fall of Arab violence, as well as the consistent increase in Jewish violence.

The final chapter deals with the plateau in the evolution of tactics experienced by the Palestine Police during and after the Second World War. With the rise of Jewish gangs and terrorist organizations along with being conscripted into military service, the force was facing a number of enemies on a number of fronts. As such this chapter focuses on the rise of violent Jewish nationalism, the war effort, and finally the conditions under which the British Empire exited the Palestine Mandate.

Certain themes run throughout this thesis on the evolution of colonial policing in and between Ireland and Palestine. The first of these is the insistence of many of the police involved that they did not wish to be treated as a military service men. Although the vast majority of the men involved were former service men themselves, they seemed to want to make a clear distinction between the two worlds of military service and civil police work. Also, and perhaps most importantly is the theme of nationalism and religion. This is a work about policing and the men who did the policing. However, the populations that these men were charged with securing 
were highly religious and had highly influential nationalist agendas. It is impossible to ignore the influence of Catholicism and Irish nationalism in Ireland. In Palestine, it is impossible to ignore Zionism and the Jewish desire for an official homeland. Finally, it is impossible to ignore the influence of Islam and the rising tide of Arab nationalism that was prevalent at the time. As such these elements will be factored into the study, but are not the primary focus. Influential figures and ideas will be explained only as they pertain to the overall understanding of policing.

Also important to this study is an explanation of the term 'terrorist'. In both Ireland and Palestine there were a number of competing religious and nationalist identities. As such, the violence perpetrated by any given party could be seen as terrorist action. For the purposes of this study the label of 'terrorists' will be limited to instances where groups or organizations intentionally target non-combatants. In Ireland and Palestine, the argument can be made that during their respective periods of study, each was an occupied territory or a warzone. It follows that attacks on British military or British security forces are not considered by this study to be acts of terrorism. However, as these attacks expand to target family members and civilians the term of 'terrorist' appears applicable.

\section{Historiography}

As this is a transnational study it stands at the confluence of several scholarly works. The first of which is D.M. Leeson's The Black and Tans: British Police and Auxiliaries in the Irish War of Independence, 1920-1921. ${ }^{2}$ In this work, Leeson attempts to give a more accurate history of being one of the earliest and most infamous of British colonial police units. The Black and Tans, a paramilitary police force used to help keep the peace during the Anglo-Irish War,

\footnotetext{
${ }^{2}$ D.M. Leeson, The Black and Tans: British Police and Auxiliaries in the Irish War of Independence, 1920-1921, (Oxford: Oxford University Press, 2012).
} 
developed a reputation of drunken, bloodthirsty British lunatics. They were seen as a murderous pack of criminals recruited from the dredges of the British penal system. Leeson uses the evidence of extensive archival research to dispel several of these myths which surround the Black and Tans. He is then able to recast the Black and Tans as World War One veterans, recruited from both British and Irish heritage who, more often than not, had atrocities mistakenly attributed to them. He adds further nuance to the situation by more accurately explaining the complex relationship that existed between the Black and Tans and the rebellious populace they attempted to police.

Leeson's work is certainly the most balanced and thoroughly researched piece of scholarship that exists on the subject of colonial policing in Ireland during the Irish War for Independence. It avoids a bias as much as a piece of scholarship can be when considering such a contentious topic and supplants the work of other writers such as Richard Bennett and William Henry. ${ }^{3}$ Yet, for all that Leeson accomplished in his work, it ends with the resolution of the war and the disbanding of the Black and Tans. This is not necessarily a shortcoming of the work, but rather an expression of Leeson's intended scope. By contrast of the current study seeks a refined understanding of not only the Black and Tans, but of all security forces within Ireland and carry it beyond the resolution of the Anglo-Irish War into Palestine.

Moving from Ireland into mandate Palestine there is another great work which has done much to improve our understanding of the British police forces that operated between 1917 and 1948. A Job Well Done: Being a History of the Palestine Police Force 1920-1948 by Edward

\footnotetext{
${ }^{3}$ Richard Bennett, The Black and Tans, (London, Edward Hulton, 1959).; William Henry, Blood for Blood: The Black and Tan War in Galway, (Cork: Mercer Press, 2012).
} 
Horne. ${ }^{4}$ Horne, a former constable of the Palestine Police Force himself, wrote a comprehensive history of the security forces at work in Mandate Palestine. He offers names, rank structures, and some larger events into which the police forces fit. When first published in 1982, Horne made good use of the archival resources available at the time, as well as his personal relationships with former Palestine Police personnel. He accomplished this in spite of the fact he had no training as a professional historian. The benefit of Horne's work is that the latter part of the book is both a history and a memoir. Although written as a history, Horne was actually there for the end of the Mandate. Further, there are a number of sources that Horne alone has had access to: personal conversations, letters, and other correspondence with men who have long since passed.

However, Horne's work, comprehensive as it may be, concerns itself with the security forces of Mandate Palestine. It does not reach back to Ireland and analyze how the two situations are bound together by the same group of men. Further, there have been a number of new sources made available since the time of the book's publishing, which shed new light on several different aspects of policing in the mandate. Some scholars such as Sean William Gannon have drawn upon some of these sources and have begun to make stronger connections between the Mandate and Ireland, but have not been able to explore deeply the Irish aspect of the equation.

One historian who has examined the colonial policing connection between mandate Palestine and pre-independence Ireland is Georgina Sinclair. Her book At the End of the Line: Colonial Policing and the Imperial Endgame 1945-1980 investigates colonial police forces at the end of empire and the legacy of 'Britishness' that lived on in former colonies. ${ }^{5}$ Sinclair analyzes

\footnotetext{
${ }^{4}$ Edward Horne, A Job Well Done: Being a History of the Palestine Police Force 1920-1948, (Sussex: The Book Guild: Sussex, 1982).

${ }^{5}$ Georgina Sinclair, At the End of the Line: Colonial Policing and the Imperial Endgame 1945-1980, (Manchester: Manchester University Press, 2006).
} 
various colonial holdings of the British Empire and how they differ from Metropolitan Police. She begins with one of the earliest and most often imitated forces in the empire, the Royal Irish Constabulary. The RIC presented a model that was emulated in Palestine, India, and Ceylon, with the idea of an almost paramilitary force that kept colonial order and reported back to a central authority. The export of British policing to the Caribbean was largely unsuccessful. Ultimately, across much of the empire, military style police forces that relied on coercion rather than consent had been in operation for so long that switching to a more traditional style of policing was not conducive to the local culture.

Sinclair, building on earlier works like The Colonial Police by Sir Charles Jeffries, does an excellent job of placing the legacy of the RIC and the Palestine Police force into an 'imperial framework' ${ }^{6}$ However, Sinclair's study it is a broader, and thinner investigation. Sinclair analyzes how the model of paramilitary policing was exported after Ireland and how it either did or didn't work with the London Metropolitan Police model. By choosing to analyze the effects in a number of British colonies, Sinclair limits the detail of each individual study.

By focusing on the deeper history at play in both Ireland and Palestine this work will be able to better understand the evolution in policing that took place between the two regions and over the course of thirty years. All of these works are remarkable pieces of scholarship however the scope of their investigation has either been too narrow or too broad to grasp the fascinating history of a transnational police force growing to fight vastly different, yet eerily similar religious and nationalist populations.

\footnotetext{
${ }^{6}$ Charles Jefferies, The Colonial Police, (London: M. Parrish, 1952).
} 


\section{Sources}

The primary source of information for this work has been gathered from the Palestine Police Collection which is housed in the Middle East Center Archive at St. Anthony's College, Oxford University. ${ }^{7}$ The collection includes the papers of a number of former members of the Palestine Police. These papers cover a wide variety of items including personal letters, dairies, daily crime reports, service registers, War Office memos, Colonial Office memos, and other official documents. Also included in this collection are copies of the British Palestine Police Magazine, as well as the publications of the British Palestine Police Old Comrades Association. Both of these periodicals have served as a way for former members of the force to share stories and stay informed on the activities of other members. Finally, there are a number of oral histories included in the collection, which have been consulted. Central to the understanding of the Irish portion of this study were oral histories collected by John Brewer. These oral histories were taken by a number of RIC, Black and Tans, and Auxiliaries. Along with these oral histories, witness statements from the Irish Bureau of Military History's online collection have been accessed. Personal memoirs proved to be a valuable source of information for each region and also for providing a common thread as some individuals, for example Douglas V. Duff, served in both Ireland and Palestine. Also helping to tie both stories together, as well as provide an official governmental perspective are parliamentary debates from both the House of Commons and House of Lords. ${ }^{8}$ Finally, a number of government acts, commissions and reports have been consulted to better understand official governmental policy and chart policing regulation and reform.

\footnotetext{
${ }^{7}$ St. Antony's College, Oxford University, Middle East Center Archive, [Hereafter (MECA)].

${ }^{8}$ Great Britain, House of Commons, Parliamentary Debate, (Hansard); Great Britain, House of Lords, Parliamentary Debate, (Hansard).
} 


\section{Chapter I: Ireland}

The Anglo-Irish War of 1919-1921 marks the final bloody chapter in the relationship between Great Britain and its longtime colonial holding, Ireland. More specifically it was the culmination of decades of struggle by Irish nationalists for the right to self-government. The demand for self-government in Ireland, or 'Home Rule' as it was termed, has a long and complicated history that resulted in harsh police action. ${ }^{9}$ Following the violent end to another attempt at Home Rule in 1916, a nationalist uprising began which lasted for several years and necessitated the Royal Irish Constabulary to supplement its ranks with World War I veterans from Britain. ${ }^{10}$ These men, who became known as the Black and Tans, along with the RIC and Auxiliaries, have left an indelible mark upon Irish history. However, it is this period that provides a foundation for the improvement of policing elsewhere in the Empire. This chapter will first detail the formative years of the Home Rule movement in Ireland along with the nationalist stirrings that it created. Next, the Easter Rising of 1916 will be examined to show its contributions to the eventual 'ambush-reprisal' dynamic between the Irish Republican Army and the Black and Tans. Also, the Royal Irish Constabulary will be examined to better understand the importance and deterioration in training standards as violence increased. Instrumental in this evaluation of Black and Tan training, ambushes, disbandment and eventual transition to the British Gendarmerie are the personal memoirs of Douglas V. Duff. ${ }^{11}$ Duff was a British

\footnotetext{
9 'Home Rule' represents a movement to end British rule in Ireland. This movement has its origins in the early nineteenth century and continued into the 1920s. While, breaking away from Britain to some extent was always a goal of this movement, complete sovereignty was not. In fact, Home Rule was most often envisioned as a system including an Irish parliament that handled domestic affairs while being subordinate to the parliament in Westminster that handled defense and foreign relations. This paper will briefly examine how the Home Rule movement holds different meaning for different groups as time progressed. Still, the majority of its incarnations did not emphasize full Irish independence. See Jeremy Smith, Britain and Ireland: From Home Rule to Independence. (Harlow: Longman, 1999).

${ }^{10}$ The Royal Irish Constabulary or 'RIC' were a police force in operation in Ireland starting in the 1830s and ending in 1922.

${ }^{11}$ The British Gendarmerie was a police force created in 1922 to maintain order in mandate Palestine.
} 
Merchant Seaman who joined the Black and Tans, and then was recruited into the British

Gendarmerie in Palestine. As such, Duff's accounts provide a common thread between the two regions. $^{12}$

\section{Home Rule and the Nationalist Rising}

To understand the context in which the Anglo-Irish War and the Black and Tans should be situated, it is necessary to examine the deep-seeded tensions between Britain and Ireland that existed throughout the history of the Irish Home Rule movement. This movement can be traced back as far as the Act of Union in $1801 .{ }^{13}$ Seeing the need to strengthen its ties to Ireland and protect itself from French threats, Britain abolished 'Grattan's Parliament' with the passing of the Act of Union. The 'Grattan Parliament' was named after Henry Grattan who only nineteen years earlier in 1782 had helped the Parliament in Ireland achieve legislative independence. ${ }^{14}$ After the dissolution of Grattan's Parliament, one hundred Irish MPs along with twenty-eight peers were absorbed into the Westminster Parliament in London. ${ }^{15}$ One major point of contention in this merger was the long standing exclusion of Catholics from the English Parliament. While many Catholics held seats in Grattan's Parliament and retained the right to vote in elections after the Act of Union, they were not permitted to hold a seat at Westminster. Attempting to change

\footnotetext{
${ }^{12}$ Douglas V. Duff, Sword For Hire; the Saga of a Modern free-companion (London: John Murray, 1934).

${ }^{13}$ Union with Ireland Act 1800 (Union with Ireland Act 1800)

http://www.legislation.gov.uk/apgb/Geo3/39-40/67/contents; For the purposes of this project, the Act of Union in 1801 was chosen as a starting point for Britain's definitive claim over Ireland. It marks a convenient spot in history to trace the narrative of Irish republican dissatisfaction. However the contentious nature of the Anglo-Irish relationship can be traced far beyond 1801 . To truly understand the long and complicated history, one would have to look back to the conquest of the Romans, Queen Elizabeth I's wars against Ireland, the Protestant ascendancy of landed elites, and a myriad of other events. Space does not allow me to include every instance throughout history that pushed the Irish to sue for independence lest it become a history of Anglo-Irish relations, and not a study of Black and Tan violence.

${ }^{14}$ R. F. Foster, Modern Ireland 1600-1972. (New York: Penguin Books, 1988), 171.

${ }^{15}$ Smith, Britain and Ireland, 10.
} 
this, Catholic Lawyer Daniel O'Connell ran for the seat in Clare in 1828 and won. The Tory government under the Duke of Wellington was faced with the decision to either let O'Connell take his seat or deny him and risk an escalation of violence and opposition from O'Connell's Catholic Associations. Realizing the potential danger in denying O’Connell his position, and alienating the Catholic majority in Ireland, the Tories relented and granted all Catholics emancipation in $1829 .{ }^{16}$

With O'Connell's election and the emancipation of the Catholics, the conversation in the 1830s and 1840s shifted from Catholic "relief" to repealing the Act of Union. It is here that we see an important factor in the formation of republican violence, and ultimately this study; that is the tactical divergence in how different groups in Ireland sought to break from Britain. ${ }^{17}$ Figures such as O'Connell attempted to break free from Britain via, slower, more constitutional means. Meanwhile, there were groups such as 'Young Irelanders' that had a nationalist base which grew increasingly more violent, especially during the potato famine of $1845 .{ }^{18}$ While, both groups sought an independent Ireland, the means by which they pursued it ran opposed to one another throughout the struggle for Home Rule until the Easter Rising in 1916.

The more violent path to Home Rule was given new life with the late $19^{\text {th }}$ century creation of the Fenians or as they were also known, the Irish Republican Brotherhood. ${ }^{19}$ This

\footnotetext{
${ }^{16}$ Smith, Britain and Ireland, 11-12.

${ }^{17}$ See R. F Foster's chapter, "The Mobilization of Popular Politics” in R. F. Foster, Modern Ireland 1600-1972 (New York: Penguin Books, 1988).

${ }^{18}$ Young Ireland was a social movement that represented the more violent side of nationalism in the mid nineteenth century. In 1848 John O'Mahony attempted an uprising in Tipperary to win back Ireland through violent means. This was also during the time of the 'Great Famine' between 1845 and 1852 See Smith, Britain and Irealnd, 22. 19 'Fenians' or 'Fenianism' is a term that is used widely to refer to Irish republican groups of the mid to late nineteenth century. It was first used by John O’Mahony, a supporter of the republican cause, who drew upon the medieval saga of Fionn Mac Cumhailand the army of 'Fianna'. This group was responsible for several attempts at uprising including the rising of 1848 and 1868. Both attempts failed due to a lack of organization. See R.F. Foster, Modern Ireland 1600-1972 (New York: Penguin Books, 1988).
} 
group and their failed attempt at rebellion in 1867 compelled then British Prime Minister

William Gladstone to reevaluate the British stance toward Ireland. As Thomas Hachey writes in his work, British and Irish Separatism, "Gladstone recognized the nationalist sentiment in Ireland, of which the Fenian movement was but a manifestation, represented a dangerous alienation from Britain on the part of the ever-increasing numbers of the Irish Catholic majority." ${ }^{20}$ There was also considerable pressure from Catholics, both domestic and abroad for the British to be removed from Ireland. ${ }^{21}$ Seeing the potential danger in this majority, Gladstone attempted to institute reform within Ireland including expanded rights for tenant farmers leasing land, as well as expanded opportunities for higher education. Gladstone was of the mind that the Irish people were a noble and hardworking group whose only defects were the result of Britain's oppression. ${ }^{22}$ These reforms were bounced back and forth in Parliament for the better part of two decades as Gladstone's Liberal Party moved in and out of power until, finally, he was able to bring the nationalists' main concern, Home Rule, before the Parliament in $1886 .{ }^{23}$ By supporting the Home Rule Bill of 1886 Gladstone was able to displace Benjamin Disraeli, the leader of the Tories, and ascend to Prime Minister once more. The terms of the bill, while not achieving everything that Irish leaders wanted, allowed for greater freedom and self-governance. However, Home Rule did not come to fruition in 1886. The House of Commons found the idea of Irish self-governance too unpalatable at the time to carry the bill through to the end. ${ }^{24}$ Despite the

\footnotetext{
${ }^{20}$ Thomas E. Hachey, Britain and Irish Separatism: From the Fenians to the Free State 1867/1922 (Chicago: Rand McNally College Publishing, 1977).

21 “Home Rule for Ireland", The Catholic World, April 1874; 19, 109. p.54.

${ }^{22}$ D.W. Bebbington, The Mind of Gladstone: Religion, Homer, and Politics (Oxford: Oxford University Press, 2004), 290.

${ }^{23}$ Hachey, British and Irish Separatism, 15-26.

${ }^{24}$ The bill came at a time when many of Britain's holdings were experience unrest including South Africa, Egypt, and Afghanistan. Therefore, despite the fact that most nationalists did not want to sever ties with the empire completely, many in Westminster felt that Irish Home Rule was a threat to the Empire itself. See Kevin Kenny, Ireland and the British Empire (Oxford, Oxford University Press, 2004).
} 
growing militant nature of the Irish Republican Brotherhood, the rejection of the Home Rule Bill of 1886 did not spark a violent rejoinder. ${ }^{25}$

While things remained relatively quiet after the death of the 1886 bill, the next decade saw an increase in tension. Following the failure of the first Home Rule bill Gladstone was able to bring a second bill to the floor in $1893 .{ }^{26}$ However, this time the bill would not find its death in the House of Commons, but rather the Conservative controlled House of Lords. This led not only to the resignation of Gladstone as Prime Minister, but also sparked an awakening of Irish nationalism and culture over the next several years. ${ }^{27}$ There was a revival of Irish culture as people found an appreciation for Irish literature, Irish athletics, and Irish solidarity. Groups such as Sinn Féin began to form, rallying around the disenfranchisement of the Irish. ${ }^{28}$ Sinn Féin, while initially a rather low level political group with few members, represented the nationalist ideal for the future of Ireland. Eventually it became the leading social and political group during the brutality of the Anglo-Irish war. It has continued to have an impact upon Irish politics, society, and culture to this day. ${ }^{29}$

Amidst this growing nationalist fervor, a third attempt at passing a Home Rule Bill was initiated in 1912. This shows that although Irish nationalists were growing in number, constitutional attempts at Home Rule were still perceived to be a possibility. The 1912 bill

\footnotetext{
${ }^{25}$ Hachey, 28; It should be noted that the Fenian Movement and the Irish Republican Brotherhood (IRB) are both used interchangeable to describe the nationalist movement within Ireland throughout the late nineteenth and early twentieth centuries.

${ }^{26}$ Bill to amend provision for Government of Ireland [as amended in Committee, and on Consideration] (Enhanced British Parliamentary Papers On Ireland) http://www.dippam.ac.uk/eppi/documents/18825/page/506444 (accessed April 27, 2015)

${ }^{27}$ Hachey, Britain and Irish Separatism, 32.

${ }^{28}$ Sinn Fein formed out of earlier nationalist movements and coalesced in 1905; Hachey, Britain and Irish Separatism, 38-57.

${ }^{29}$ Sinn Fein was founded in 1905 by Arthur Griffith and when translated from Gaelic means 'Ourselves' or 'We are It'. See Richard Bennett, The Black and Tans (London: Edward Hulton, 1959), 11.
} 
offered an Irish legislature in Dublin, as well as Irish representation in the Westminster

Parliament. While the terms were acceptable to the nationalists, the minority Protestant unionists saw themselves being underrepresented in a system that would presumably be dominated by Catholics. This led to the formation of two opposing forces; the Ulster Volunteers comprised of unionist Protestant Irish, and the Irish Volunteers consisting of primarily Catholic, republican Irish. The former was, of course opposed to the idea of home rule and any legislation that severed ties with Great Britain, while the latter was in favor of the bill. Meanwhile both formed militant groups prepared to fight whomever for primacy on the issue. ${ }^{30}$ As these groups formed, small pockets of violence began to break out. Despite the violence, the 'Government of Ireland Act' was passed in 1914 and was given Royal assent with the caveat that home rule would not take effect until after the resolution of World War I. ${ }^{31}$ While this was certainly a victory for those who sought to sever ties with Britain by peaceful means, some Irish republicans found the delay to be unacceptable.

What these early chapters in Home Rule demonstrate is the repeated frustration felt by the Irish republicans. The vacillation back and forth so many times on the issue caused more and more people to be drawn to the cause, and the movement in turn took on an increasingly martial attitude. Conversely, as Irish nationalists began to receive concessions from Britain, the Protestant minority especially in the North, saw an erosion of representation within Ireland.

\footnotetext{
${ }^{30}$ Hachey, Britain and Irish Separatism, 69-70; The republicans in Ireland were always hoping for full autonomy and self-government from the British. Although this was always what they were aiming for, most understood it was not going to be realized all at once. The fight for full home rule would be won piece by piece. The term 'unionist' refers to a group that opposes the breaking away from Britain. This however, does not necessarily mean that the group did not support Home Rule. Unionist can simply denote that the group wishes to have a legislature in Ireland, separate from Westminster. Still, the Ulster unionists did not seek a separate legislature. This was because any Irish legislature meant diminished representation for the Protestant minority.

${ }^{31}$ Hachey, British and Irish Separatism, 95; The Government in Ireland Act, as well as the Welsh Church Act were put on hold by the Suspensory Act of 1914. See HC Deb 17 September 1914 vol 66 cc991-6.
} 
Tensions were mounting as World War I began, which set the stage for continued conflict between the Irish and Great Britain. As Ireland contributed a significant number of men to the war there were those who saw the conflict as a chance to force greater autonomy. ${ }^{32}$

Contemporary writer R.C. Escouflaire noted that Ireland's food supplies were vital to the British war effort. He went on to write, "If she refuses to send over her surplus... what a catastrophe there would be! Well, without Home Rule, she tries to play this scurvy trick; the Sinn Féiners intimidate the farmers who want to export their pigs, and vow that if they were masters it would be their supreme joy to starve the accursed English. The old motto still triumphs, "'England's difficulty is Ireland's opportunity." ${ }^{\prime 33}$ Naturally, this created a serious national security problem for Britain. As the war continued the British military was forced to devote valuable intelligence agents to keep an eye on nationalists who were thought to sympathize with the Germans. As Escouflaire noted, "Sinn Féin began to talk of 'our brave allies the Germans,' ... Obviously Irish sympathies were drawing closer and closer to Berlin." ${ }^{34}$ These fears became reality when evidence of the circumstances leading up to the Easter Rising of 1916 were uncovered.

\section{The Easter Rising}

The Easter Rising began in 1916 amidst the confusion and chaos of the First World War.

The British government had been gathering intelligence that led them to believe the Irish

\footnotetext{
${ }^{32}$ The number of Irish soldiers who served in the British Army and Navy during World War I is disputed among historians. However, the number of 210, 000 is provided by Professor Keith Jeffery and is widely recognized by British and Irish historians as a reliable number. Further, Jeffery's numbers estimate that at least 35,000 Irish died in the war. See "Irish Soldiers in the First World War," Department of the Taoisearch last modified 2013, accessed December 17, 2015 http://www.taoiseach.gov.ie/eng/Historical_Information/1916_Commemorations/Irish_Soldiers_in_the_First_World War.html

${ }^{33}$ R.C. Esouflaire was a French writer who wrote about the complex relationship between England, Ireland, and France. See R.C. Escouflaire, Ireland: An Enemy of the Allies, trans. R.C. Escouflaire (New York: E.P. Dutton \& Company, 1920), 140.

${ }^{34}$ Escouflaire, Ireland, 184.
} 
nationalists were connected in some sort of arrangement with the Germans. It was not until the $12^{\text {th }}$ of April that the British intercepted a message that the Germans were to supply the Irish nationalists with twenty-thousand rifles, ten machine guns and five million rounds of ammunition. ${ }^{35}$ Further, British diplomat turned Irish rebel, Sir Roger Casement was being transported back to Ireland by U-boat around the same time. The British seized the munitions, as well as Casement on the $22^{\text {nd }}$ of April. This proved to be a crucial blow to the Easter Rising. During his trial, following the rebel defeat in Dublin a letter was produced written by their leader Padraig Pearse, saying, "I understand that the German expedition on which I was counting actually set sail but was defeated by the British." ${ }^{36}$ Pearse was counting on the arrival of the German munitions so he could properly arm his men for the planned uprising. At this point the British saw the need to arrest all the prominent leaders of the Irish Volunteers and Sinn Féin. Unbeknown to the British, the rebels were planning to attack strategic sites within Dublin on the $24^{\text {th }}$ of April, 1916, Easter Monday.

The Rising began, without German armaments, when Padraig Pearse, naming himself Commandant-General of the Irish Republican Army, occupied the General Post Office in Dublin. ${ }^{37}$ At the same time several other strategic points such as the Jacob's Biscuit Factory, the Four Courts, St. Stephens Green, the South Dublin Workhouse, and Boland's Flour Mill were taken by future Sinn Féin leader Eamon de Valera. After occupying these positions the rebels thought that the citizens of Dublin would flock to their cause. However, leaders of the movement severely undercut their connection to the people by allying themselves with the Germans and thus the Central Powers. With many of Ireland's young men fighting against the Central Powers

\footnotetext{
35 Peter Cottrell, The Anglo-Irish War: The Trouble of 1913-1922 (Oxford: Osprey Publishing Ltd., 2006 ), 32.

${ }^{36}$ Sean Enright, Easter Rising 1916: The Trials (Kildare: Merrion, 2014), 90.

${ }^{37}$ By this point the Irish Volunteers were becoming even more militant and began to call themselves the Irish Republican Army (IRA). After the Rising they are called by this name almost exclusively.
} 
in World War I, the citizens of Dublin were not compelled to support the IRA's militant action. As Richard Bennett wrote in his work The Black and Tans, "Never in the history of Ireland had a rebellion inspired so little sympathy. There were nearly a hundred thousand Catholic Irishmen fighting with the British Army, and the rebellion seemed as much a stab in the back to the majority of Irish people as it did to the English." ${ }^{38}$ Even without the support of the Dublin citizens, the IRA had no real strategy beyond the occupation of these positions. The plan was to occupy and wait for the British response.

The first response came not from the British, but from two Irish battalions, the $3^{\text {rd }}$ Royal Irish Rifle and the $10^{\text {th }}$ Royal Dublin Fusiliers. The two battalions pinned the rebels down with heavy shelling from field guns, as well as from the HMS Asgard which added to the Dublin bombardment from the river Liffey. In the days that followed, over sixteen-thousand troops entered the city and pinned the I.R.A in their remaining positions. It was at this point that Commandant-General Pearse saw that the Rising was a failure. ${ }^{39}$ He had lost sixty-four men, the civilian casualties were at 210 with over six hundred wounded, while the British had only lost 134 soldiers. $^{40}$

Following the Rising in Dublin, the rebels were put on trial. As it was wartime, the rebels were tried in an all military court which was allowed by subsection one of the 'Defence of the Realm Act'. It was reasonable to assume that the members of the IRA and Sinn Féin who took

\footnotetext{
${ }^{38}$ Bennett, The Black and Tans, 14.

${ }^{39}$ Tom Barry, a member of the IRA during the Anglo-Irish War who was part of many ambushes on R.I.C, Auxiliary, and Black and Tan units has expressed his assessment that while he is proud of the sacrifice of the Easter Rising, the plan for it was a complete military failure. It is important to note that Barry is one of the most frequently used sources in IRA history. "Tom Barry talk on Guerilla Warfare - Part 2," Youtube last modified July 11, 2013, accessed November 21, 2014. https://www.youtube.com/watch?v=25O8MkLxBWc

${ }^{40}$ Cottrell, The Anglo Irish War, 34-35.
} 
part in such treasonous activities would be executed. ${ }^{41}$ Indeed many, including Pearse, were executed on 3 May, $1916 .{ }^{42}$ His final statement in the military court was:

My sole object in surrendering unconditionally was to save the slaughter of the civil population and to save the lives of our followers who had been led into this thing by us. It is my hope that the British government who has shown its strength will also be magnanimous and spare the lives and give an amnesty to my followers, as I am one of the persons chiefly responsible, have acted as $\mathrm{C}$ in $\mathrm{C}$ and president of the provisional government. I am prepared to take the consequences of my act. But I went down on my knees as a child and told God that I would work all my life to gain the freedom of Ireland. I have deemed it my duty as an Irishman to have organized men to fight against Britain. ${ }^{43}$

While Pearse and several other key members of the IRA and Sinn Féin were executed, there were those such as Eamon de Valera and Michael Collins who managed to escape execution. In total 160 rebels were tried by the military courts and fifteen were executed. ${ }^{44}$ It is important to note de Valera and Collins managed to escape execution, as they soon became two of the most prominent figures in the Anglo-Irish War. Certainly, there were none who created more problems for the British, and specifically the Black and Tans, than Michael Collins. While the trials were going on, in London Prime Minister Asquith announced the names of those who were to be executed to a House of Commons that bore no objection. However, it was MP John Redmond who foresaw the violence to come with the comment, “...that out of the ashes of this miserable tragedy there may spring up something that may re-bound." ${ }^{45}$ Certainly this sentiment could be felt as those who were not sentenced to death were marched toward cattle boats for deportation and imprisonment. Men who were previously jeered by Dublin citizens for their

\footnotetext{
${ }^{41}$ Defense of the Realm Act 1914 (First World War) http://www.nationalarchives.gov.uk/pathways/firstworldwar/first_world_war/p_defence.htm.

${ }^{42}$ Enright, The Easter Rising 1916, 32.

${ }^{43}$ Enright, Easter Rising 1916, 90.

${ }^{44}$ Cottrell, The Anglo Irish War, 35.

${ }^{45}$ John Redmond was a member of the House of Commons and advocate of Irish nationalism. Enright, 34.
} 
foolish and haphazard Rising were then met with cheers of adoration when they returned home.

The manner in which the British handled the trials of the republicans, and their subsequent executions, did far more to stir nationalist fervor in Ireland than it did to quell it. ${ }^{46}$

Following the executions of the sixteen rebels a wave of pro-nationalist and pro-Sinn Féin sentiment swept over the country. ${ }^{47}$ The situation was made even more tense by the termination of yet another attempt at Home Rule. The crux of the issue was the inclusion of a plan for partitioning Ulster in the north, from the republican South. The republicans were strongly opposed to partition wanting a united Ireland, meanwhile Ulster unionists would not support any Home Rule attempt as long as it did not have partition at the heart of it.

With support for Sinn Féin at its height, the party swept the 1918 elections with seventythree constituencies to the Unionists' twenty-five, and the Irish Parliamentary Party's meager seven. It is this point that served to embolden Irish republicans. They saw Sinn Féin and other elected candidates not as members of the Westminster Parliament of Great Britain, but rather as the acting parliament of Ireland, known as the Dáil Éireann. ${ }^{48}$ Soon thereafter, Eamon de Valera was appointed President of the Dáil and Prime Minister of Ireland following his escape from Lincoln Gaol. ${ }^{49}$ Along with de Valera the de facto government was established when the Offices of State were filled by members of the Irish Republican Brotherhood, or those who had connections to it including Minister of Finance Michael Collins. It is important to consider that

\footnotetext{
${ }^{46}$ Maureen Buckley, "Irish Easter Rising of 1916," Social Science, Vol. 31, No. 1 (January, 1956): 55.

${ }^{47}$ This wave, of course, missed the Protestants in Ireland and especially in Ulster who remained firm unionists and opposed to Sinn Fein.

${ }^{48}$ The Dáil Éireann is the Gaelic term for an Irish Parliament separate from the Parliament in Westminster. It represented a sort of 'government in waiting'.

${ }^{49}$ Lincoln Gaol is a prison facility in Lincolnshire, England used, at the time, to hold convicted rebels from Easter

Rising who managed to avoid execution.
} 
while republicans saw the Dublin-based Dáil as the legitimate parliament in Ireland, Britain in no way recognized it. ${ }^{50}$

It is clear that the Easter Rising marks a turning point in the means by which autonomy would be sought. Violence was the new form of negotiation. With the execution of the I.R.A and Sinn Féin leaders, the British only served to make martyrs for the cause. There was no going back for either side, with the result being several years of war and bloodshed before the two sides would be brought back to the table for negotiations.

\section{The State of Policing in Ireland}

Prior to the arrival of the Black and Tans, as well as other supplemental auxiliary units, the Royal Irish Constabulary had been the principal police force in Ireland. This force was established in May of 1836 with the primary directive to maintain law and order beyond the boundaries of any one city or county. ${ }^{51}$ Prior to this time police forces operated in the individual counties and were ruled by a Chief Inspector. After Sir Robert Peel was appointed as Home Secretary in 1812 the police system saw a reorganization. After forming the London Metropolitan Police Force in 1829, Peel quickly earned a reputation as an expert in policing. Although Peel initiated the reformation of policing in Ireland, he did not see its conclusion as Home Secretary. As Thomas Fennell, a former constable recalls, "[a] belief generally held was that the police of Peel's time as Chief Secretary was the same Force that came down from that time as the RIC. This was quite a mistaken view." ${ }^{52}$ Rather, it was more than six years after Peel had stepped down as Home Secretary that the Constabulary Act and its amendment received

\footnotetext{
50 Peter Cottrell, Brendan O’Shea, and Gerry White, The War for Ireland: 1913-1923 (Oxford: Osprey Publishing Ltd., 2009), 85.

${ }^{51}$ Great Britian House of Commons, Parliamentary Debate 18 May 1836, vol 33 cc1084-5. [Hereafter cited as HC].

52 Thomas, Fennell, The Royal Irish Constabulary: A History and Personal Memoir (University College of Dublin Press: Dublin, 2003), 5
} 
royal assent on 28 July, 1836 as Acts 6 and 7 William IV. ${ }^{53}$ Fennell recounts that though Peel did not establish the RIC, members of the force were often still given the derogatory nickname 'Peelers'.54

Regardless of who drafted the legislation that brought the RIC to life, the force was comprised mostly of Catholic Irish. This was a significant change from traditional practice, which barred Catholics from serving in any police force. However, the Catholic Emancipation Act of 1829 ensured that the non-officer ranks of the RIC were filled with Catholics. Meanwhile, the officers were almost entirely Protestant.

At this point it is important to discuss the term 'paramilitary'. The police forces considered in this study can all be considered paramilitary police forces. The RIC, the Black and Tans, the Auxiliaries, the British Gendarmerie, and the Palestine Police cannot be classified in the same category as a force such as the British Metropolitan Police. The real difference between a traditional force such as the British Metropolitan Police and paramilitary force is the kind of tasks that are required of them. Metropolitans police carry out the duties that commonly come to mind when thinking about police work; criminal investigation, apprehension of suspects, and working with the judicial system to levy appropriate punishments for crime. Paramilitary police forces are asked to carry out these duties, as well as duties that more closely resemble military operations. These operations can include, at least for the forces considered in this study, armed patrol, bomb removal, armed escort operations, and intelligence gathering. Perhaps the most visible distinction between traditional police and paramilitary police is how they are armed. The British Metropolitan Police, for example were not armed and routinely carried out unarmed foot

\footnotetext{
${ }^{53}$ Great Britain, House of Lords, Parliamentary Debate 28 July 1836, vol. 35 c603. [Hereafter cited as HL]

${ }^{54}$ Fennell, The Royal Irish Constabulary, 7.
} 
patrols. Meanwhile, the forces considered in this study were trained in the use of pistols, rifles, and automatic weapons and often carried out mounted patrols in armored cars. Essentially, paramilitary police were responsible for all the duties of a traditional police officer, yet also needed to be capable of fulfilling any extraordinary duty in a specific region.

Fennell recounts that although the official founding of the RIC took place in 1836, the real birth of a paramilitary force didn't happen until 1840 with the establishment of the Royal Irish Constabulary Depot, Phoenix Park. It was here that men were trained and drilled in a military fashion. They wore military style uniforms and always had former military officers in the upper echelon of command. ${ }^{55}$ Initially they were given normal police duties; keeping the peace and investigating crimes. However, perhaps their most important duty, especially in the eyes of the British Government, was to help in the collection of land taxes. This practice carried with it the perpetuation of landlordism within Ireland. Fennell tells us that many of the recruits did not realize that this would be such a large part of their job until several years into the service. By that time, "no matter how distasteful it was, they had then in most cases reached a time when they were obliged to continue." 56 Many of the men had families to support and could not afford to quit. The young recruit spent his first several years in the Depot training and drilling until a vacancy opened up in a county. By the time the constable finally was sent to his post it was likely that he had already married and started a family. This practice of helping to collect taxes did not sit well with the constable or the general populace of Ireland. Still, this did not manifest into animosity between the people and the RIC. Citizens knew that the constables were obliged

\footnotetext{
${ }^{55}$ Fennell, The Royal Irish Constabulary, 8-9.

${ }^{56}$ Fennell, The Royal Irish Constabulary, 11.
} 
to do a job that they also found distasteful. ${ }^{57}$ This relationship would remain relatively unchanged until the start of the Anglo-Irish War in 1920.

During the war, the nature of policing for the RIC changed. The force certainly retained their military foundation, but its real talent was in the gathering of intelligence. Georgina Sinclair describes them as being “designed to keep Ireland's population under what amounted to colonial subjugation, the RIC developed as a centralized body of armed men. In carrying out extraneous duties, the RIC effectively became the "eyes and ears' of government..."58 Given this proficiency in intelligence gathering, the Irish Volunteers saw the RIC as high value targets. Understanding the importance of hindering RIC activities, rebel members of the Irish Volunteers first stole a shipment of explosives in Soloheadbeg, County Tipperary, and killed two police constables in the process on the 21 January 1919. The rebels went on to kill fifteen more constables throughout the year. However, the tipping point came with the failed assassination attempt on Viscount French, the Lord Lieutenant of Ireland on 19 December 1919. Following this action, things began to move quickly as D.M. Leeson describes: “Beginning on January 1920, the British Army was given special powers to combat the insurgents, and the security forces carried out mass arrests of republican leaders." ${ }^{, 59}$ These powers included the detention of large groups of suspects, as well as becoming a much more heavily armed force. Although the Royal Irish Constabulary was extremely well trained and disciplined, they were not prepared to fight a guerilla war. Leeson makes reference to a large number of men who began to resign because of the new, more brutal nature of their work. Along with this new work came a partition plan that

\footnotetext{
${ }^{57}$ Fennell, The Royal Irish Constabulary, 12.

${ }^{58}$ Georgina Sinclair, At the End of the Line: Colonial Policing and the Imperial Endgame 1945-1980 (Manchester: Manchester University Press, 2006), 222.

${ }^{59}$ D.M. Leeson, The Black and Tans: British Police and Auxiliaries in the Irish War of Independence, 1920-1921 (Oxford: Oxford University Press, 2011), 8.
} 
divided Ulster from the rest of the country along with the establishment of provincial parliaments for each in 1920. The partition only served to instigate the nationalists because of Ulster's loyalty to the crown. All the while more police were being killed.

Amidst the mounting violence, it is important to note that there were moments of chivalric behavior in the early days of the conflict. As Cottrell points out, “...there were instances of the IRA shouting warnings before they opened fire, and of policemen giving up their service revolvers and Lee Enfield .303cal rifles without a fight and being sent on their way."60 However, as time went on gentlemanly acts such as these became almost nonexistent. The Irish Volunteers, being referred to almost exclusively as the IRA by this time, began to ambush Royal Irish Constabulary patrols and barracks in the spring and summer of 1920, killing eighty-three constables. Also, Michael Collins began to run highly successful counter-intelligence operations that effectively neutralized any advantage the British may have had enjoyed. Bennett describes Collins as cycling, “...every day from his Ministry of Finance offices in Mary Street and St. Andrew's Street to his Intelligence Office at No. 5 Mespil Road, where he sat working behind lace curtains, a revolver on his desk." ${ }^{\prime 61}$ The situation had become dire. With the Constabulary on the verge of collapse and Collins outwitting the intelligence service, there was not much hope for the British to restore order. ${ }^{62}$

\footnotetext{
${ }^{60}$ Cottrell, The War for Ireland, 90.

${ }^{61}$ Bennett, The Black and Tans, 51.

${ }^{62}$ The Royal Irish Constabulary began to falter because their numbers were in sharp decline. Many men were leaving the service because they didn't sign up in the 1890s for the kind of work that was being required of them, while other left in fear of their life. Still others thought it was their patriotic duty to not serve the force any longer. As one Constable J.J. McConnell wrote, "Resignations from the Force grew from a trickle to a steady stream, the motives being genuine patriotism, pressure from terrified parents and wives, and sometimes personal fear, as shootings of police were of daily occurrence. Recruiting from the original native source almost came to a standstill." See Bureau of Military History. Statement by Witness, Statement by J.J. McConnell, Document No. W.S. 509,17 May 1951. http://www.bureauofmilitaryhistory.ie/reels/bmh/BMH.WS0509.pdf (accessed March 1, 2015).
} 
The training that the RIC underwent seems to have been of a high quality. It combined not only military-style drill, but also rigorous examination on police work. As one recruit described the training, "Phoenix Park was tough, it was far worse than the army, the drill, oh, it was tough, although you were glad to have some kind of job. ${ }^{\prime 63}$ However, it is clear that there was some kind of balance that existed between the physical requirements of the job and the necessary discipline of knowing the law and being able to enforce it. To this end it appears that if recruits were unable grasp the law and order aspect of their duties, they were held back. William Dunn, who joined the RIC in 1917, recalls the standards for examinations: "the Commandant had you out there in the square and then you were taken in the school and you had to pass through all those things. We worked fairly hard, you know, I mean you had to, you didn't want to be put back." ${ }^{\circ 4}$ This insistence on knowing the law and being able to enforce it is vital to understanding the deterioration of policing standards in Ireland during the Anglo-Irish War. As the situation became increasingly violent, more emphasis was placed upon the military aspects of the job and police knowledge became secondary.

\section{Ambush and Reprisal: Black and Tan Violence in the Anglo-Irish War}

Britain's answer to violence was the hotly contested 'Restoration of Order in Ireland Act'. ${ }^{65}$ Following this act the face of 'policing' changed in Ireland. As Leeson describes the situation, the Royal Irish Constabulary became "an irregular military force, bound by neither military law nor military discipline..."66 It was at this point in March of

\footnotetext{
${ }^{63}$ John D. Brewer, The Royal Irish Constabulary: An Oral History (Antrim: W.G. Baird, Ltd., 1990), 50

${ }^{64}$ Brewer, Dunn, 48-49.

${ }^{65}$ The Restoration of Order in Ireland Act of 1920 was an act passed by Parliament on August $9^{\text {th }} 1920$ which expanded the Defence of the Realm Acts. The primary directive of the act was hold Irish nationalists accountable for their actions without having to declare martial law. However, martial law would be declared only five months later. See HC Deb 09 August 1920 vol 133 cc136-7

${ }^{66}$ Leeson, The Black and Tans, 16.
} 
1920 that the Royal Irish Constabulary began to recruit ex-British soldiers to supplement its faltering numbers. ${ }^{67}$ The Constabulary was not logistically prepared for such a great influx of recruits. They were forced to cobble together uniforms by either wearing a khaki tunic and dark green pants, or dressed entirely in British military khaki. The uniform was also outfitted with a black leather belt, sometimes a black leather trench coat, and often a dark green tam-o'-shanter cap. ${ }^{68}$ Upon arriving in Limerick, the locals began to call the units 'The Black and Tans', likening their appearance to a famous pack of hunting dogs. Along with the uniforms, these new recruits were paid a handsome sum of ten shillings per day. ${ }^{69}$ This high rate of pay was very attractive for many former service men who had returned home and found it difficult to find work. ${ }^{70}$

When the men recruited for the unit arrived in Ireland, it was necessary for them to be trained as quickly as possible because of the urgency and high rate of attrition among officers. One individual who had experience early on in the Anglo-Irish War and beyond was Douglas Valder Duff. During World War I, Duff served aboard the H.M.S Conway, as well as the Thracia in service of the Merchant Navy at the early age of thirteen. In 1917 Duff's ship was sunk by a German U-Boat leaving him as the only survivor. Soon thereafter, Duff's next ship, Flavia, was also torpedoed by a German U-Boat. For nearly two years after the war Duff entered a monastery to become monk in fulfilment of a promise he made to himself while floating amongst the flotsam and jetsam of the Thracia. Despite his time as a monk, Duff moved on to join the Black

\footnotetext{
${ }^{67}$ The difference between what are considered RIC regulars and the Black and Tans comes from the time that they were recruited. The Black and Tans were signed into service in January of 1920. These later recruits received different uniforms than the earlier RIC recruits and thus were seen as distinct.

${ }^{68}$ The tam-o'shanter was another piece of British military apparel. The bonnet like cap was traditionally worn by Scottish regiments.

${ }^{69}$ William Henry, Blood for Blood: The Black and Tan War in Galway (Cork: Mercer Press, 2012), 50.

${ }^{70}$ Leeson, The Black and Tans, 76.
} 
and Tans for over a year. ${ }^{71}$ Duff recalls his training in Ireland being very rushed and feeble in its pretense of effectiveness. Still, the type of training a recruit received depended upon what kind of experience they had prior to their posting in Ireland. Duff recounts the Head Constable Major saying, "All you scabs that have served in the Infantry will receive three days' training and will then be posed to County stations."72 Meanwhile any recruits that had experience in the cavalry, artillery, technical corps, Navy, Air Force, Merchant Service, or coming in as civilians, were to receive up to a month of training before being sent out to their stations. Duff lied about being in the Infantry in order to avoid a prolonged training regimen. This shortened version of training consisted of an afternoon of explosive and small arm instruction, followed by a day of classroom instruction on the laws the men were going to enforce. This is important to note as these men were expected to keep law and order, but many only received one day of instruction on the law. By the third morning, the recruits were considered fully trained and ready for action. ${ }^{73}$ As Duff was ambushed on his first escort mission he mused about how quickly his old life as a monk had transitioned into something very different: “A week ago, I had been meek Brother Lawrence, scared of my portly, sallow Provincial, now I was here, firing with intent to kill an armed enemy who had just done his utmost to cut short my career."74 What Duff's account shows us is that the men drawn into the Black and Tans were barely trained beyond their previous military training. What training they did receive certainly did not prepare them to maintain order by regular means as civil policemen.

\footnotetext{
${ }^{71}$ Following his time in Ireland, Duff moved immediately to Palestine to serve with the British Gendarmerie. Duff fell in love with Palestine and spent over ten years in the region. Aside from his extremely colorful life, Duff was a prolific author writing well over one hundred titles including his memoirs, and an account of a visit to Palestine after his retirement.

${ }^{72}$ Douglas Duff, Sword for Hire: The Saga of a Modern Free-Companion (London: John Murray, 1934), 59.

${ }^{73}$ Duff, Sword for Hire, 60-61.

${ }^{74}$ Duff, Sword for Hire, 61.
} 
For those who did not have any military experience they could look forward to a month of training with a heavy emphasis on military-style drill. George Crawford, who joined in June 1920, described the process as follows:

At the time it was all military training, you were got up by bugle in the morning at six o' clock, revile went at six and tattoo went at ten at night, and you answered roll-call. From six in the morning till five in the evening you were continually at drill. At school we did Acts of Parliament and all sorts of police duties. The whole day was taken up and you never had more than about fifteen minutes between each, either school or drill or gym. We were taught bayonet fighting and the usual military stuff. ${ }^{75}$

While Crawford does describe 'police duties' as part of the training, it is clear from other accounts that the policing aspect of training was not given priority. This is exacerbated by the fact that most of these recruits were largely uneducated. Robert Crossett, who joined in 1920 and became a member of the Black and Tans, recalled many 'sad' memories of training. Although he claimed to have a great memory and was able to remember some pieces of information from the Police Manual, he "wasn't able to read well and every school [session] was a battle." 76 He went on to say, 'I wasn't a good policeman. I was a good enough policeman, I done the work as well as any of them, but if I had been left on my own, like, I would have been hopeless." ${ }^{\text {77 }}$ Between the former service men who received little training in police work, and the former farmers who had just recently been taught military expertise, the new recruits who were posted throughout Ireland were ill prepared to peacefully and effectively subdue a hostile population.

It did not take long for the rest of Black and Tans to begin their work. Following the assassination of a head constable in Balbriggan, County Dublin on September $20^{\text {th, }} 1920$, the

\footnotetext{
${ }^{75}$ Brewer, The Royal Irish Constabulary: An Oral History, 46

${ }^{76}$ Brewer, The Royal Irish Constabulary: An Oral History, 47.

${ }^{77}$ Brewer, The Royal Irish Constabulary: An Oral History, 47.
} 
Black and Tans laid waste to the town. By the end of the night two men were killed, over fortynine houses were either razed or badly damaged, four public houses were looted and subsequently burned, and finally a hosiery factory was destroyed. ${ }^{78}$ The Black and Tans in concert with the Royal Irish Constabulary regulars made it known that any rebel activities taken up by the I.R.A would be met with frightening reprisals.

The question then is why did the Black and Tans resort to such overwhelmingly violent responses to republican violence? Many historians have argued that the Black and Tans were damaged products of the First World War. The argument has been that the Black and Tans' previous training and experience in trench warfare did not translate into effective policing of IRA guerrilla warfare. While this is all true Leeson goes further to assert that it was the Royal Irish Constabulary who showed the Black and Tans the order of business in Ireland. As he writes, the “...Black and Tans, had military training and combat experience, but they were fish out of water in Ireland, where they soon picked up the bad habits of their Irish comrades, and worse."79 While it may be the case that the Constabulary used harsh tactics, the Black and Tans took violence to new heights during their time in Ireland. Following the Balbriggan reprisal the Tans made it very clear to the citizens of Drogheda that they were here to keep order, and that order would be kept by all necessary means. This warning was printed in the Advocate, as well as canvassed across the town,

\section{DROGHEDA BEWARE}

If in the vicinity a policeman is shot, five of the leading Sinn Féiners will be shot. It is not coercion - it is an eye for an eye. We are not drink-maddened savages as we have been described in the Dublin rags. We are not out for loot. We are inoffensive to women. We are as humane as other Christians, but we have restrained ourselves for too long. Are we to lie down while our comrades are

\footnotetext{
${ }^{78}$ Leeson, The Black and Tans, 26.

${ }^{79}$ Leeson, The Black and Tans, 38.
} 
being shot in cold blood by the coroner boys and ragamuffins of Ireland? We say 'Never', and all the inquires in the world will not stop our desire for revenge. Stop the shooting of police, or we will lay low every house that smells of Sinn Féin. Remember Balbriggan.

$$
\text { (By Order) Black and Tans. }{ }^{80}
$$

Warnings such as this did little to dissuade the IRA from continuing their pattern of surprise attacks on the Black and Tans. In most cases, the violence only increased.

There were some counties in Ireland where the level of violence was higher than others. The IRA and the Black and Tans had a particularly bloody history in County Galway. The conflict first began with the ambush of a Black and Tan patrol on July $19^{\text {th, }}$ 1920 which left two dead. Following this ambush, the constables ransacked the town looking for those responsible. Amidst the chaos, several buildings were set ablaze, some with women and children still inside. Unable to find those responsible, the Tans moved to homes of known Sinn Féin members. In one instance Eamon Casey's door was kicked in and he was ordered out at gunpoint. William Henry in his work, Blood for Blood: The Black and Tan War in Galway, describes the Tans entering Casey's home: "his wife, who was standing in the hall, implored them not to kill her husband. One of the policemen raised his rifle to hit her; he stopped when Casey asked them not to kill him in front of her. The head constable then intervened and order his men out of the house. Before releasing Casey, the policemen warned him that they would 'get' him within three weeks. ${ }^{\prime 81}$ Casey was not the only target of this kind of harassment. In the ensuing month I.R.A commanding officer, Michael Moran was arrested, imprisoned, set free, rearrested,

\footnotetext{
${ }^{80}$ Advocate, 7 October 1920 NLA accessed November 20, 2014 http://trove.nla.gov.au/ndp/del/printArticlePdf/66601809/3?print=n.

${ }^{81}$ Henry, Blood for Blood, 69.
} 
and finally murdered while in Black and Tan custody. During his funeral procession the Black and Tans attempted to break the ranks of IRA members following the hearse. ${ }^{82}$

Similar attacks continued through the following months. One particularly brazen ambush took place less than a mile from Renmore Barracks in Oranmore, County Galway on August $21^{\text {st }}$. As the police patrol made its way through Merlin Park, they passed under a bridge toward a hilled area beyond. The plan was, that once the patrol had made it past the bridge, IRA men atop the bridge would open fire, and the real ambush would come from the hilled areas on either side of the road. However, the two men on the bridge, Baby Duggan and Maurice Mullins, opened fire too early not allowing for the ambush to be sprung. Still, in retreat constable Martin Foley was shot and killed while the others returned to Renmore to raise the alarm. After Black and Tans had investigated the scene, they showed some measure of restraint that night in their questioning of the townsfolk. This restraint was slowly chipped away by various fights that broke out during their investigation. Eventually, the inquiries devolved into the usual brand of Black and Tan justice. The police went to known republican houses shooting indiscriminately and setting them on fire. ${ }^{83}$ An article in The New Republic described the situations in Oranamore as follows:

The fact that the successful insurrection in Ireland irritates and bores the average Englishman instead of infuriating him, will of course, encourage the Irish nationalists to persist. No doubt a mixture of irritation may breed temporary callousness to the means which are used to obtain relief, but when these means fail an irritated and bored public is not likely to insist indefinitely in its ill-doing ${ }^{84}$

\footnotetext{
${ }^{82}$ Henry, Blood for Blood, 60-71.

${ }^{83}$ Henry, Blood for Blood, 73-79.

${ }^{84}$ The New Republic October 27, 1920
} 
What is important about these instances in Galway is that they were representative of the violence occurring throughout the country. ${ }^{85}$ Ambushes and assassinations in one county inspired not only more ambushes and assassinations in other counties, but also police reprisals. It was reported in The Times that police forces in County Longford burned down the homes of local Sinn Féin leaders while yelling, 'Up Tuam!' ${ }^{86}$ Hence, we see a cyclical pattern of republican violence being met with even greater reprisals from the Black and Tans. As summer faded into fall the numbers started to add up; the British in Ireland "...had lost fifty-four police and twelve soldiers killed. One hundred police and fifty-four soldiers had been wounded, and forty-nine police and eighty soldiers were disarmed; thirty-three court houses had been destroyed and seventeen damaged; eight defended barracks had been destroyed, four damaged and twenty unsuccessfully attacked." 87

What came following the back and forth violence of the summer and fall was an event widely considered to be a turning point in the conflict, as well as one of the most crucial moments in the republican cause; Bloody Sunday. While there are several events in Irish history that have earned the title, 'Bloody Sunday' that occurred on the $21^{\text {st }}$ of November, 1920 , is arguably the most prominent. It began with Michael Collins' need to cripple British intelligence in Dublin. Through clandestine sources, Collins gathered the names of several prominent British intelligence members and put together a group of assassins to carry out a coordinated attack. ${ }^{88}$

\footnotetext{
${ }^{85}$ Events such as these are recounted in various memoirs and oral histories including that of Mary J. Ryan who recounts her father and grandfather's life in County Tipperary. "An Irish American Oral History" Youtube last modified on Jan 4, 2011, accessed November 23, 2014 https://www.youtube.com/watch?v=NBxuJcxB15o.

${ }^{86}$ The Times, 24 July 1920.

${ }^{87}$ Bennett, The Black and Tans, 103.

${ }^{88}$ The source of Collins' information regarding the British secret service is a mysterious character called 'Lt. G'. As is described by J.B.E. Hittle, Collins acquired a source who had direct access to senior level contacts within British Intelligence. Collins never revealed who this source was, but the information gathered was crucial to the enactment of 'Bloody Sunday'. J.B.E. Hittle, Michael Collins and the AngloIrish War: Britain's Counterinsurgency Failure (Lincoln: Potomac Books Inc.; 2011).
} 
On the morning of November $21^{\text {st }}$ the assassins, many of whom were part of Collins elite 'Squad,' forced their way into homes throughout Dublin and carried out the deed. ${ }^{89}$ Some of the attacks were thwarted by security forces, still, many of the names Collins had gathered were murdered in their beds. By the end of the day, "Fourteen bodies, nine of them in pyjamas, were taken to the morgue..." $" 90$ Several of those killed were not on the list, but by Collins' own admission had to be taken care of for what they had seen. ${ }^{91}$ The following day the blood letting continued when security forces looking for the 'Bloody Sunday' perpetrators fired into a crowd of civilians at a football match in Croke Park. ${ }^{92}$

The events in Galway and Dublin previously described represent the kind of large-scale attack and reprisal engagements that characterized the relationship between the I.R.A and the Black and Tans. However, in these engagements the body counts were relatively low. Starting in December 1920 martial law was declared in Ireland as violence began to increase. This continued throughout most of 1921, albeit on a smaller, but more frequent 'tit for tat' basis. All the while, Prime Minister Lloyd George was pursuing a truce with de Valera and Collins. ${ }^{93}$ It is strange to think that all of these events were running alongside one another. General Nevil Macready rhetorically asked, "Where except in Ireland, or possibly in a South American Republic, could open rebellion, martial law, peace proposals and a General Election be all running side by side?" 94 On July $8^{\text {th, }} 1921$ a truce was negotiated that would eventually lead to

\footnotetext{
89 'The Squad' was a trusted group of assassins that Michael Collins had put together shortly after he was named Minister of Finance. This group was usually tasked with counter-intelligence missions.

${ }^{90}$ Bennett, The Black and Tans, 126.

${ }^{91}$ Benett, The Black and Tans, 120-127.

92 "The Black and Tans," BBC last modified September 24, 2014, accessed on November 19, 2014. http://www.bbc.co.uk/history/british/easterrising/aftermath/af05.shtml

${ }^{93}$ In 1921 de Valera and Collins were reelected to the Dial in an election where Sinn Fein won all but four seats. Hachey, British and Irish Separatism, 282.

${ }^{94}$ Bennett,1 The Black and Tans, 198.
} 
the Anglo-Irish Treaty in December. ${ }^{95}$ Under the Treaty the 'Southern Irish Free State' became a self- governing dominion under Great Britain. In addition it received complete independence in its domestic affairs. As the New Republic described the agreement, "It is not a new idea, but it looks promising today because it evades the difficulty of surrender of territory by Ulster, it preserves the unity of Ireland, which would be shattered by a boundary commission operating a new partition, and it holds out the prospect of an increasing measure of unity..." ${ }^{\circ 6}$ While this agreement upset many nationalists in Ireland who felt that Ulster should be part of the republic, the treaty was signed all the same. Still, the empire was losing one of its longest held colonial possessions, and some felt that it was for the best. As The New Republic reported, "the immediate threat to the security of the British Empire comes not from the abandonment of military rule over rebellious people but from its continuation." 97 Regardless, the war was over for the Black and Tans who were dismissed from their duties. Violence did not leave the Emerald Isle, but the blood was no longer going to be on the hands of the Black and Tans and Auxiliaries. ${ }^{98}$ With their disbandment many were left without work. There were those who returned to Britain and a normal life. However, the British Empire had great need for their particular set of skills elsewhere. Members of the Royal Irish Constabulary, and especially the Black and Tans, reenlisted to aid in the development of colonial policing throughout the empire. ${ }^{99}$ One area where many Black and Tans, including Duff, found themselves was in Palestine serving under the newly formed 'British Gendarmerie'. ${ }^{100}$ From this background of relatively poor training, the

\footnotetext{
95“Anglo-Irish Treaty - 6 December 1921" The National Archives of Ireland last updated 2002, accessed on December 17, 2015, http://treaty.nationalarchives.ie/document-gallery/anglo-irish-treaty-6-december-1921/. 96 The New Republic, December 14, 1921.

97 The New Republic, October 27 1920, p. 206.

${ }^{98}$ Despite the truce in July, Black and Tan recruitment continued until the 20th of December 1921, over two weeks after the signing of the treaty. See, "The Black and Tans - who were they?" War of Independence last modified in 2011, accessed on November 22, 2014, http://www.warofindependence.info/?page_id=505.

${ }^{99}$ HC Deb 09 February 1922 vol 150 cc270-1270.

${ }^{100}$ Duff, Sword for Hire, 92.
} 
security forces used the real-world experience gained in Ireland, and built upon it in the Palestine Mandate.

What the Anglo-Irish War represents, as far as the evolution of British colonial policing is concerned is a foundation from which policing could grow. The RIC was already established as a reliable and effective police force yet as the war began, new inexperienced recruits were taken on and not properly trained in traditional police methods. Instead the security forces had to rely on the military training that most of them had acquired during the First World War. This lack of training when coupled with a population that was committed to breaking away the British Empire meant that violence was all but unavoidable. Still, as a large portion of the security forces in Ireland moved into the Palestine Mandate, the lessons learned served to improve the efficiency of British colonial policing over the next twenty-five years. 


\section{Chapter II: Transition and the Holy Land}

In Palestine, the situation into which the security forces from Ireland were entering was completely unknown to them. At the time of their departure from Europe a number of developments had occurred in the Middle East. The First World War had ended and Britain was charged with the stewardship of the Palestine Mandate. The Palestine Police had been established, and in its infancy, had already faced a number of challenges. Perhaps most importantly, Jewish immigrants were coming into the region, and Arabs living in Palestine perceived the threat of being pushed into an economic and territorial periphery as a result of increased immigration.

The security forces faced other challenges before even setting foot in the Holy Land. The Black and Tans and Auxiliaries had earned a reputation for brutal tactics and bad behavior in Ireland. Many wondered if this same brand of policing was going to be exported to Palestine. Also, these men were entering into a battle between competing nationalist movements. These nationalist conflicts in many respects were unique to Palestine, but in some respects were quite similar to those at play in Ireland.

Despite the challenges, these men managed to overcome many of the difficulties facing them. The bloody reputation of Ireland did not follow them very far into the Mandate. In fact, considering the time in which the Irish security forces entered the Palestine Mandate, it is remarkable to learn that the period of the Gendarmerie was the most peaceful in the territory's history. It is the object of this chapter to chart the transition of the security forces from Ireland into the Palestine Mandate in order to demonstrate the evolution in policing methods. This is done first by examining the situation in the Middle East during and after the First World War as it pertains to the Palestine Mandate. Next, an account of policing in the Mandate is given to 
address: the establishment of the Palestine Police, the recruitment of the Irish security forces into the British Gendarmerie, and finally their training and activities during the Mandate. Lastly, the disbanding of the British Gendarmerie and its absorption into the Palestine Police is discussed and analyzed.

\section{The Middle East During and After the First World War}

It is important to understand the origins of the Mandate in order to appreciate the preexisting tensions encountered by security forces in Palestine. Moreover, the political decisions made, the conditions of Imperial control, and influx of Jewish settlers led directly to a dangerous situation that was both unique and strikingly similar to that of Ireland during the Anglo-Irish War. The Mandate was created because it was the opinion of European Leaders that the region could not govern itself and would need a fair amount of facilitation before selfgovernment could be achieved. However, two years after the end of World War II Palestine was one of the few territories in the region that had not been moved along the path toward selfgovernment. $^{101}$

During the First World War, the British Government knew that success in the Middle East and the fall of the Ottoman Empire meant that stewardship of the region would fall upon them as victors. As it has already been suggested, we cannot really claim to understand the underlying motivations of Irish nationalists without understanding the contentious history that existed between Ireland and Great Britain. So too in the case of Palestine. An understanding of how the Palestine Mandate came to be allows us to better understand the fragile situation into which police forces were placed. The promises made on behalf of the British Government to

\footnotetext{
${ }^{101}$ Naomi Shepard, Ploughing Sand: British Rule in Palestine 1917-1948 (New Brunswick: Rutgers University Press, 1999), 5
} 
Zionist and Arab leaders sowed the seeds of discontent and rebellion. The fruits of British labor would then have to be tended to years later by the security forces charged with policing the Mandate. This section will examine the British, French, and Jewish elements that came together during and after the First World War to plan spheres of influence within the 'Near East' and how they created a situation of accelerated nationalism.

Around the same time the Easter Rising was taking place in Ireland, the Triple Entente was making plans for the end of World War I. Anticipating the fall of the Ottoman Empire, the British and French in November of 1915, began to discuss how the Middle East would be divided up and controlled following the war. ${ }^{102}$ By 16 May 1916, Britain and France, led in secret discussion by Sir Mark Sykes and Francois Georges-Picot, settled upon the Sykes-Picot Agreement, officially known as the Asia Minor Agreement. ${ }^{103}$ By the terms of this arrangement, the Arab provinces of the Ottoman Empire were divided between the British and French. The British would be given control of the Haifa, Acre, Southern Iraq and the coastal region between the Mediterranean Sea and the River Jordan. ${ }^{104}$ Meanwhile the French were to be given Lebanon, Syria, Northern Iraq, and Southeastern Turkey. ${ }^{105}$ In years to follow, Sykes saw the strategic importance of the Palestine region. In correspondence with Picot, Sykes began to broach the

\footnotetext{
102 Before moving forward it is important to make a note of a purposeful choice on terminology. Throughout this paper the term 'Arab' will be used to refer to what today, we would commonly think of as 'Palestinians'. As this work focuses on a time prior to the establishment of Israel and to avoid confusion the term 'Arabs' will be used. The group that is being referred to as 'Arabs' must be recognized as a diverse one with its own class structure and religious diversity. The 'Arabs' discussed do not necessarily act as a monolith and as such the greatest efforts will be made to distinguish between competing ideologies and actions within the community.

103 “Sykes-Picot Agreement” BYU WWI Document Archive. Accessed on December 17, 2015.

"http://wwi.lib.byu.edu/index.php/Sykes-Picot_Agreement

104 The agreement made plans only for Arab provinces outside of the Arabian peninsula.

${ }^{105}$ Itzhak, Galnoor. The Partition of Palestine: Decision Crossroads in the Zionist Movement, (New York: University of New York Press 1995), 36-39. Also see Naomi Shepard, Ploughing Sand: British Rule in Palestine, 1917-1948. (New Brunswick: Rutgers University Press, 2000), 20-73.
} 
subject of the Entente's interest in the future of Palestine, in reference to the area between the

Jordan and the Mediterranean. ${ }^{106}$

This agreement, however, did not address the Zionist desire for the establishment of a

Jewish homeland. ${ }^{107}$ For several reasons, the British government and Foreign Secretary Arthur

James Balfour saw a Jewish homeland in Palestine as a necessity for postwar stability in the

region. In letters between Balfour and future Zionist leader Chaim Weizmann, Jewish

nationalism was at the heart of the desire for a homeland. According to Weizmann, those true to

the Jewish faith were represented by those who expressed Jewish nationalism and Jewish

democracy. ${ }^{108}$ With that end in mind Balfour issued the famous Balfour Declaration in a letter to

Zionist advocate, Lord Walter Rothschild, in November 1917. As the letter reads,

His Majesty's Government view with favour the establishment in Palestine of a national home for the Jewish people, and will use their best endeavours to facilitate the achievement of this object, it being clearly understood that nothing shall be done which may prejudice the civil and religious rights of existing non-

\footnotetext{
106 The letter also goes on to broach the subject of Jewish settlement and better define the area which became the Mandate, "Starting form this point we then proceeded to study the map of Palestine, and the dispersion of the existing Jewish colonies there. You will notice that with a few exceptions North of Haifa there are almost wholly in the area which is generally regarded as Palestine... Coming to the country round Haifa and the arable lands East of the Jordan and South of Jerusalem...I told him that these were areas in which Great Britain and France had a special secular and political interest, as apart from other powers, and that provided a just understanding could be come to with the Arabs, I apprehended that there need be no great difficulties in the way. In this I felt sure you would agree." See St. Anthony's College, Oxford, Middle East Center Archive, Sir Mark Sykes Papers, GB 165-0275, [Hereafter Sykes Papers GB 165-0275 (MECA)], Letter from Sir Mark Sykes to Georges Picot, February $28^{\text {th }} 1917$.

${ }^{107}$ Zionism represents a nationalist and political movement to establish a Jewish homeland. Starting at the end of the nineteenth century with Theodor Herzl the movement figures prominently into the conversation about Mandate Palestine and its policing. Many of the incidents handled by the British Gendarmerie and Palestine Police stem from Jewish settlement instigated by the Zionist movement. See Edward Horne, A Job Well Done: Being a History of the Palestine Police Force 1920-1948 (Sussex: The Book Guild, 1982), 28-31; Douglas Duff also offers is own assessment of Zionism and Jews by writing, "The Jews, too, are not united. The great majority are Zionists, people who believe in the restoration of their race to its homeland. They devote their lives to the realization of this ideal, one that becomes all the dearer with the rising tide of anti-Semitism in Europe. The difference between them and the Mizrachi, or orthodox Jews, is that the Zionists believe in the nationhood of Israel, and use Hebrew as their everyday speech; whilst the orthodox think of Jewry as a religion, are extremely conservative in their religious opinion, and hold that Hebrew is a sacred tongue which must be used only for devotional purposes." See Douglas V. Duff, The Rough With the Smooth (London: J.M. Dent \& Sons LTD., 1940), 124.

${ }^{108}$ Letter 514, To Arthur J. Balfour, London, 3 October 1917 English: T.W.:P.R.O. - F.O. 371/3083, F. 143082, No. 171885. See The Letters and Papers of Chaim Weizmann: Volume VII, Series A, August 1914-November 1917, Meyer W. Weisgal, Gen. Ed. (Jerusalem: Israel University Press, 1975), Page 521-522
} 
Jewish communities in Palestine, or the rights and political status enjoyed by Jews in any other country. ${ }^{109}$

As the Balfour Declaration was made public in 1917 and the secret Sykes-Picot agreement was revealed during the Bolshevik Revolution of the same year, both the Jews and Arabs felt that their interests were not going to be met by the conflicting terms of the agreements. This was exacerbated by the promises made by the British Government to Sharif Hussein and his sons to transfer the Islamic Caliphate to them in return for their support against the Turks during World War I. These matters were further complicated by other conflicting promises made by the McMahon letters. ${ }^{110}$ To Arabs, the idea of not having an independent state free from British control ran counter to promises that had been made earlier in the war. For Zionists, the wording of the Balfour Declaration was not clear enough in specifically promising a Jewish state. ${ }^{111}$

Over the next six years, even with the ending of the war, the exact boundaries of the mandate were still being debated. ${ }^{112}$ It was not until September 29, 1923 after the signing of the Treaty of Lausanne that the mandate was considered to be in full effect. ${ }^{113}$ However, this did not

\footnotetext{
109 "The Balfour Declaration," Israel Ministry of Foreign Affairs last updated 2013. Accessed on December 20, 2015. http://www.mfa.gov.il/mfa/foreignpolicy/peace/guide/pages/the\%20balfour\%20declaration.aspx; It is important to note that when Sykes was making his reports to the War Office, Balfour was present for many of the meetings and was well aware of the Jewish settlement already taking place in the region.

${ }^{110}$ The McMahon letters were a series of correspondence between the British High Commissioner in Egypt, Sir Henry McMahon and the Sharif of Mecca, Hussein ibn Ali which outlined the areas to be given to Arabs. Absent from these lands was Palestine. See Mitchell Bard, "Pre-State Israel: The Hussein-McMahon Correspondence." Accessed on December 12, 2015. http://www.jewishvirtuallibrary.org/jsource/History/hussmac.html.

${ }^{111}$ There was a lengthy debate over how the security of Palestine should be paid for. Many thought that wealthy Zionists should assume full financial responsibility for the region. However, Under-Secretary of State for the Colonies E. Wood assured them that, "His Majesty's Government is of opinion that it is incumbent upon them to accept the responsibilities, financial or other, which such a position involves." See HC Deb 20 June 1921 vol 143 c885.

${ }^{112}$ After the Ottoman Empire was surrendered on October 30, 1918, British and French forces were left in control of the region. Drafting the mandate was a lengthy process dealing with concerned groups including Arabs who feared the influence of Zionists leaders. A draft was formally approved by the League of Nations on 24 July 1922. See Horne, 40-41.

113 “Treaty of Lausanne," BYU WWI Document Archive last updated 2009. Accessed on December 17, 2015. http://wwi.lib.byu.edu/index.php/Treaty_of_Lausanne
} 
stop Jews from migrating into their promised land. With the steady influx of Jewish settlers

combined with an unhappy Palestinian Arab population, and a haphazard British presence in the region, the situation quickly escalated. ${ }^{114}$

Attacks upon Jewish settlers became increasingly frequent and violent. In order to combat this the British government sought to establish the British Gendarmerie, a paramilitary police force that could protect the influx of Jewish settlers, as well as carry out a variety of normal police actions. The British Gendarmerie became Winston Churchill's solution to alleviating the cost of garrisoning 7,000 British World War I soldiers in Palestine while also maintaining peace in the region. ${ }^{115}$ The cost of keeping these troops in Palestine during 1922 was $£ 1,724,000 .^{116}$

\section{The State of Policing in Palestine}

As former Palestine Police officer Edward Horne has written, "For Great Britain, police work in Palestine began at the moment the first allied soldier set foot over the Egyptian border..."117 Horne here is referring to January 9, 1917 when British military forces pushed through Turkish lines and claimed their first position in Palestine. It was at that point that the

\footnotetext{
${ }^{114}$ Many authors have placed the failure of the mandate upon the terms set forth in the Balfour Declaration as well as in the Mandate agreement. Nick Reynold has written that, "In the first place, the planning and preparation of the Balfour Declaration, and later of the Mandate Agreement were badly flawed. The authors of these two documents, while committing Great Britain to the role of assisting in the creation of a Jewish Homeland in Palestine, completely failed to anticipate the reaction to such a Homeland by the Arabs, who made up 93 percent of the country's total population. The mistaken evaluation of potential Arab power, my first reason for Great Britain's failure to achieve its ambition in Palestine, could have been successfully dealt with, had it not been for the second reason for the nonfulfillment, which was the absence of goodwill and empathy on the part of many British politicians in Whitehall and many of the administration personnel in Palestine toward Zionism and Zionists during the entire mandate period. See Nick Reynold, Britain's Unfulfilled Mandate for Palestine (London: Lexington Books, 2014), xvii-xix. ${ }^{115}$ Sean William Gannon, "The Formation, Composition, and Conduct of the British Section of the Palestine Gendarmerie, 1922-1926," in The Historical Journal, 56, pp977-1006, 979-980. The question of what the Army was still doing in Palestine left many without answers. Even in reports to parliament their real purpose was unclear. See HC Deb 09 May 1922 vol 153 cc1984-5.; Also, at work within the country was the Palestine Police Force. However, the force was still in its infancy and working to bring together the disparate municipal forces.

${ }^{116}$ HC Deb 10 May 1922 vol 153 cc2213-4W

${ }^{117}$ Horne, A Job Well Done, 11.
} 
military administration became responsible for the security of Palestine. As the military continued to move through the region and occupy towns, it was common practice for an officer to stay behind as Town Governor and impose military order so as to maintain public security and peace. It was on December 9, 1917 that Jerusalem fell to British forces. The occupation and transition to British administration was a relatively smooth process. The military found, in most cases, a decently trained municipal police force that was capable of working under military rule. In each of the towns a local police force existed, which operated independently of and did not cooperate with other localities. Horne notes that the military was always eager to shed its responsibility for public security as it was simply not what they were trained for. Moreover, due to low pay there was simply no way that a force could be recruited locally. ${ }^{118}$ By November 1918 all of Palestine was firmly under the control of British military administration and the war had come to a close.

With the end of hostilities, the administration of the region had to be revisited and so the Occupied Enemy Territory Administration or OETA was established. The OETA was subdivided into more manageable segments of which Palestine fell into the district of OETA South and was under the purview of Major General Sir Harry Watson. It was Watson who highlighted the necessity for a unified police force that was not subject to each locality. This mirrors the same kind of directive that initiated the Constabulary Act of 1836 which created the Royal Irish Constabulary. In both instances it was seen that a police force needed to be centrally controlled and able to operate beyond the boundaries of a county or town. Watson left the task of bringing

\footnotetext{
${ }^{118}$ See Edward Horne, A Job Well Done, 15-20.
} 
the well-trained municipal forces and the less reputable town forces together to Lt. Col. Percy B. Bramley. ${ }^{119}$

Arriving in July, 1919, Bramley quickly began to take account of what he had to work with in Palestine, traveling to stations across the region. He found the Turkish officers to be a well-trained and reliable. One question that struck Bramley early on was the kind of uniform his men would wear. As has already been shown in the previous chapter on Ireland, the uniform the colonial police wore had a tendency to be one of the most recognizable and memorable aspects of the police themselves. Although the Black and Tans were not yet formed at this time, their uniforms are by far their most distinguishing visual element. Palestine was no exception.

Bramley knew that he needed to find a uniform that was adaptable to the climate that varied from extremely cold in the hill-country winter and extremely hot in the summer valley regions. The traditional Turkish uniform varied greatly and often did little to distinguish the policeman from the average citizen. Thus, Bramley decided a standard blue tunic uniform for the winter and khaki tunics with shorts for the summer. As for headdress, the Kalpak was decided upon because it was not particularly ascribed to any religious or ethnic group. ${ }^{120}$

The uniting of municipal forces under Bramley technically gave rise to the Palestine Police Fore. However it was not officially recognized until a year later. ${ }^{121}$ Still, during that time

\footnotetext{
${ }^{119}$ Bramley, the scion of an old Yorkshire family was born, educated, and employed in India. He had previously served as the Deputy Inspector-General Police for the United Provinces of India. During his time as Deputy Inspector-General he was highly decorated. Further, he was a World War I veteran having served first in India and then in the Middle East. See Horne, A Job Well Done, 23.

${ }^{120}$ Horne, A Job Well Done, 24-25.

${ }^{121}$ Horne, A Job Well Done, 27. Chaim Weizmann later wrote to Lloyd George, "Instigation [and] propaganda unchecked for two years bore its fruits. Jerusalem, where anti-Jewish excesses did not happen since the Crusades, has been for three days the scene of wild pogroms massacres, looting and violating of Jewish women. Government protection unwillingly granted and inadequate. Arab gendarmes participated [in the] excesses. Respectfully claim that the ringleaders be severely punished and Arab clubs and propaganda centres closed. Furthermore, [we] demand fifty percent Jewish gendarmes, also dismissal President Mayor [of] Municipality, who always manifested public anti-Jewish feelings. Finally demand impartial investigation at which Jewish participation granted for establishing responsibility and [securing] punishment [of] authors of trouble." See, Letter 302. To David Lloyd George, London.
} 
the force performed its duties well and only had one considerable incident to speak of; the Jabotinsky Riots of 1920. The Jabotinsky Riot, also known as the Nebi Musa Riots, were a series of riots that took place during the Nabi Musa festival between the $4^{\text {th }}$ and $7^{\text {th }}$ of April 1920 . The riots were a result of heightened tension between the relatively small number of Jewish settlers and Arabs in the region. Zionist leader Vladimir Jabotinsky helped to excite the tension between Jews and Arabs during the Nebi Musa parade. ${ }^{122}$ According to reports, as the riot commenced on the morning of the $4^{\text {th }}$, "it became necessary to reinforce the police by military assistance. The police are believed to have sided with their co-religionists, and were withdrawn and disarmed." 123 The rioting continued, unchanged through the $5^{\text {th }}$ and $6^{\text {th }}$ leaving two dead and 186 wounded when rioting abated on the $7^{\text {th }}$. The debate in Parliament concluded when Colonel Wilfrid Ashley asked, "What steps have been taken to protect the Jews in their own country...?" To which Mr. Bonar Law responded, “As my hon. and gallant Friend knows, meantime responsibility for Palestine is on General Allenby, and I am sure that he is taking all proper steps." 124

This riot and the subsequent debate that ensued in Parliament reveals a great deal about the beginning of the policing, Arab-Jewish relations, and British official regard for both. This moment in time was an unfortunate blemish on an otherwise commendable service record of the early Palestine Police. It happened while Bramley was in the middle of really establishing the force and uniting the municipal police. The fact that Col. Ashley refers to the 'Jews in their own country' does suggest that some may have had pro-Zionist leanings. Certainly there were many

10 April 1920. English: T.:Copy. T.W.:C.Z.A. A18/33/2. In, The Letters and Papers of Chaim Weizmann: Volume IX, Series A, October 1918-July 1920. Meyer W. Weisgal, Gen. Ed. (Jerusalem: Israel University Press, 1977), Page 333-334

122 Horne, 29.

${ }^{123}$ HC Deb 14 April 1920, vol 127 cc1674-5

${ }^{124}$ HC Deb 14 April 1920, vol 127 cc1674-5 
who sought to remain neutral toward the Zionist cause as there was already a great deal of international support for Jewish settlement in the region. Yet, it is important to note that Jabotinsky was himself an immigrant to Jerusalem, and that it was Jabotinsky that incited the riots with inflammatory speeches during the parade. Finally, we see from this debate that there was a great amount of trust placed in military control of the region under Gen. Allenby. Yet there is no mention, other than of their failure, of the police force.

Despite this early failing it can be said that the Palestine Police existed in name only when the riot occurred and were completely ill-equipped to handle something it. In official terms the Palestine Police were established on July 1, 1920 under the terms of the mandate granted to Great Britain by the League of Nations. However it was not until later in the summer that the force resembled anything official. By that time Bramley was able to name his senior aides, including Major Alan Saunders, Major W.F. Wainright, F.A. Partridge, and E.V. Holdridge. The force at that time had a strength of 1,515 men comprised of sixteen British Officers, fifty five Palestinian Officers and 1,444 other ranks. These 'other ranks' were locally recruited, welltrained policemen who had received comprehensive instruction prior to the outbreak of World War I. ${ }^{125}$ The next year, the force was supplemented with five-hundred locally procured men known as the Palestine Gendarmerie. This separate force included the traditional 'policeman-onfoot' as well as constables on horseback and camelback. The primary directive of this force was to control the border region. ${ }^{126}$ Still, even with the remarkable work done by Bramley, the force did not have an established character. The disparate elements of a number of local police took some time to solidify. This took another two years and the exit of the majority of military forces

\footnotetext{
125 St. Antony's College, Oxford University, Middle East Center Archive, The British Palestine Police Association Magazine, [Hereafter The British Palestine Police Association Magazine, (MECA)], Spring 2014, 12.

126 The British Palestine Police Association Magazine, (MECA), Spring, 2014, 12.
} 
for this character to emerge. The military's exit, by design of Winston Churchill, coincided with the last piece of the Palestine security puzzle; the British Gendarmerie.

\section{The British Gendarmerie and the Recruitment of the Irish Contingent}

Prior to the formation of the British section of the Palestine Police, Winston Churchill decided to create the British Gendarmerie. This decision was made after a conference in March of 1921 , which called together British experts committed to understanding the delicate situation in the region. It was decided that the cost of garrisoning Palestine with troops was financially too expensive for the Empire to bear. Although the military had been doing its best to keep the peace, they were soldiers, not police officers. They simply did not have the requisite skill or training to be effective. Furthermore, the military's dissatisfaction with the Zionist immigration complicated their continued stay in Palestine. ${ }^{127}$ Following the withdrawal of a significant portion of the military presence, a new force was needed to help fill the void and assist the local police force with tasks that fell outside the realm of normative police duties such as border patrol, immigration control, and inter-district communication. ${ }^{128}$ Churchill, who had recently been Colonial Secretary, wanted to transplant the model of the Royal Canadian Mounted Police into Palestine. ${ }^{129}$ This model had a heavy emphasis on mounted patrols, especially horse mounted patrols. The date most often cited as the beginning of the British Gendarmerie in Palestine is July 1, 1921 when news of the force was published in the Palestine Gazette.

\footnotetext{
${ }^{127}$ Quoted in Keith Jeffery, The British Army and the Crisis of Empire, 1918-1922 (Manchester: Manchester University Press), p 128-129.

128 These tasks generally dealt with things such as escort duties as well as immigration and smuggling control. See Horne, A Job Well Done, 65.

${ }^{129}$ The Royal Canadian Mounted Police are also known as the Gendarmerie royale du Canada, as well as the 'Mounties' The editor of the British Palestine Police Association notes that it is unknown as to why Churchill decided to use the French term 'Gendarmerie' for the British force in Palestine. See, British Palestine Police Association Magazine, (MECA), Spring 2014 p. 17.
} 
Churchill sought to fill the ranks of the Gendarmerie with locally recruited men who were under the direction of British officers. However, he soon found out as the summer of 1921 gave way to autumn that the force would need to be primarily comprised of Brits as locals were in short supply. Further supporting this change was the de-escalation in Ireland. With the prospect of Black and Tans and Auxiliaries soon to be out of work, Churchill saw the opportunity to provide these men with a career in policing.

According to then Colonel Angus McNeil, the British Gendarmerie was established with forty nine officers and 685 other ranks. ${ }^{130}$ These men were broken down into six companies, each of which received four Ford Touring vehicles, four Ford Tenders, and four Lewis guns. ${ }^{131}$ McNeil goes on to write that seventy percent of the Gendarmerie was comprised of RIC regulars, as well as the Black and Tans, while thirty percent were drawn from the Auxiliary division. The men were relatively young averaging twenty-six years old. They also had more time in military service than police service; the average constable had four years in the military opposed to one year nine months as a police officer. ${ }^{132}$

For many of these constables the choice to join the Gendarmerie stemmed from the impetus for so much of human action: money and fear. As peace drew closer in Ireland, many constables knew the disbanding of their unit was not far off. Just as the Black and Tans offered a lucrative job opportunity in 1920, the Gendarmerie presented the promise of continued

\footnotetext{
${ }^{130}$ These 'other ranks' simply refers to those men who were not in the upper echelons of command.

${ }^{131}$ McNeil makes special note of the reliability of the Ford cars writing, "The Mechanical Transport (Ford Cars) have proved very satisfactory and recently came out of two several desert tests, against Crossleys and Rolls Royce, with flying colours." See St. Antony's College, Oxford University, Angus McNeil Papers GB165-0197, Middle East Center Archives,[Hereafter McNeil Papers GB165-0197, (MECA)], Notes on the British Gendarmerie, $3^{\text {rd }}$ January, p 4.

${ }^{132}$ McNeil Papers GB165-0197, (MECA), Notes on the British Gendarmerie, $3^{\text {rd }}$ January 1923.; The diaries of Col. McNeil are some of the best remaining accounts of the Gendarmerie. After its dissolution in 1926 all of the records relating to the Gendarmerie were lost or destroyed.
} 
employment. ${ }^{133}$ Employment options in both Ireland and England were slim. The primarily agrarian economy of Ireland was hit especially hard in the post-World War I and postAnglo/Irish War economic slump. Agriculture was overwhelmingly the previous occupation of constables. ${ }^{134}$ Gannon has estimated that more than one third of the Irish-born RIC came from agricultural households which no long needed their labor after the peace. One London-born Black and Tan, Walter Harrison, insisted that job prospects even beyond agriculture were bleak for those men who had only known work in the military and paramilitary police services. To men like Harrison the Gendarmerie seemed like the obvious decision. ${ }^{135}$

The second aspect motivating men nearing the end of their tenure in Ireland was fear of reprisal from a resentful Irish populace, and to a greater extent, violent nationalists who were slow to forget the wrongs done to them by the RIC, the Black and Tans, and the Auxiliaries. As Harrison remarked of the impending peace: "If one was a loyalist, that is, if one was non-Irish, then one must get out."136 A similar sentiment was shared by Douglas Duff in his memoir Bailing Water with a Teaspoon. ${ }^{137}$ It is clear from several of these sources that if any of these men, especially those who were English-born, were to stay in Ireland there would almost certainly be some form of violent retribution. One former RIC constable from the Irish Free State told author John Brewer in an oral history that many constables "just could not go home... They had to go away because some men after going home were shot at for going home even though they were disbanded and out of a job. A lot of them went to the Palestine Police." ${ }^{138}$ It is

\footnotetext{
${ }^{133}$ In 1920 men in Gormanston were interviewed by the Manchester Guardian and specifically cited the threat of joblessness as a primary factor in choosing to ender the Black and Tans. See Leeson, 77.

${ }^{134}$ Sean Gannon, “'Sure it's only a Holiday...':The Irish Contingent of the British (Palestine) Gendarmerie, $1922-$ 1926" in Austrlasian Journal of Irish Studies 13 (2013),pp.64-8570.

135 Sean Gannon, "'Sure it's only a Holiday...', 68.

${ }^{136}$ Quoted in, Gannon 'Sure it's only a Holiday...”, 70.

${ }^{137}$ Douglas Duff, Bailing Water with A Teaspoon, 19.

${ }^{138}$ Brewer, The Royal Irish Constabulary: An Oral History, 118-119.
} 
important to remember that the ambush/reprisal dynamic that existed between the police forces in Ireland and Irish nationalists continued up to and beyond the peace agreement. Bearing all of this in mind, it is no surprise that as constables faced their disbandment by immediately taking the opportunity to sign up for the Gendarmerie. ${ }^{139}$

As it became clear that the ranks of the British Gendarmerie were to be filled with agents of Empire who had earned a considerable and negative reputation in Ireland, there were many who thought that the brutal nature of policing would be exported to Palestine. Kent Fedorowich has documented well the fear that gave the British Government pause when considering recruiting the Black and Tans. As he has written, the Black and Tans “...conjured up scenes of barbarity and brutality to which none wanted to be linked." 140 This obviously created a problem as the Irish security forces were to be the primary pool from which the Gendarmerie was recruited. Churchill knew that there was no way to make the transition covertly. He decided that the announcement of the Gendarmerie's formation would be made without mentioning the recruitment of the Black and Tans. To further avoid the connection between the Gendarmerie and the Irish contingent, the announcement was made from London rather than Dublin. On January 17,1922 , the official release stated only that units which were to be disbanded that year would be recruited into the Gendarmerie. However, this attempt at misdirection did not succeed as the Central News Agency in London revealed that the disbanded units were, in fact the infamous Black and Tans. ${ }^{141}$

\footnotetext{
${ }^{139}$ All of the Brewer's participants, as well as the families that took part in Gannon's project cited probable IRA retribution as the overwhelming reason for enlistment into the British Gendarmerie. See Gannon, "Sure it's only a holiday...", 72 .

${ }^{140}$ Kent Fedorowich, 'The Problems of Disbandment: The Royal Irish Constabulary and Imperial Migration' in Irish Historical Studies, vol. 30, 1996, p 101.

${ }^{141}$ Sean Gannon, 'The Formation, Composition, and Conduct of the British Section of the Palestine Gendarmerie, 1922-1926,' The Historical Journal, 56, 4 (2013), pp.977-1006, 986.
} 
The next step was to name a commandant to take control of the men recruited. The proposed date of April $1^{\text {st }}$ was approaching fast and after some deliberation it was decided that the Boer War and First World War veteran, Col. Angus John McNeil, was a suitable candidate. Aside from his previous military experience during the Boer War, his time in the First World War allowed him to become well acquainted with Palestine and the region in general. McNeil and his second-in-command, Major Gerald Foley, quickly began to sort through applications to find the most qualified constables. Instrumental in assisting Foley and McNeil in selecting recruits for the Gendarmerie was Major-General Sir Hugh Tudor. Tudor's experience as commander of all security forces in Ireland made him well qualified to find the best possible recruits for service. However, Tudor's association with the process only served to cement the idea of Irish brutality being exported to Palestine. The same man in charge of all security forces in Ireland was now helping to establish and shape the new Gendarmerie in Palestine. Moreover, Tudor was named Inspector General of Police and Prisons only three months after the arrival of the British Gendarmerie recruits in Palestine. This promotion put Tudor in charge of all security forces in Palestine including the British Gendarmerie, the Palestine Gendarmerie, the Palestine Police and any military units left in the country. ${ }^{142}$

To anyone looking at the situation of recruitment, which had been reported on by a number of newspapers, it was not unreasonable to think that the tactics used by the Black and Tans in Ireland would continue in Palestine. ${ }^{143}$ All of the men in charge of recruitment, Tudor,

\footnotetext{
${ }^{142}$ Horne, A Job Well Done, 52.

${ }^{143}$ As it has been stated earlier, all parties involved in the recruitment process were trying to downplay the involvement of RIC, Black and Tan, and Auxiliary forces. However, publications such as the Palestine Weekly and the Freeman's Journal in London exposed the real nature of recruitment. Soon thereafter other newspapers such as the Sunday Times, Irish Independent, the Evening Standard, the Jewish Chronicle, Irish Times, the Times and the Western Morning News and Mercury all were reporting on the recruitment of the Irish contingent. See Sean Gannon, The Formation Composition..., 990.
} 
McNeil, and Foley, had far more experience serving as military officers than police officers. Further, the reprisals carried out by the Black and Tans had taken place under Tudor's overall command. Public fears of the same kind of reprisals taking place in Palestine were perhaps, initially, well justified. Despite these fears, the British Gendarmerie showed great restraint during their service as will be shown in the next section.

\section{The British Gendarmerie in Palestine}

Of all the men who traveled to Palestine after the disbanding of the Black and Tans, Douglas Duff is the only one who has left a full account of his time from Ireland to Palestine and beyond. After accepting a position in the Gendarmerie, Duff visited his father who had been ill and then proceeded on to Plymouth, to begin training at Fort Tregantle. Upon arrival the quartermaster assigned Duff to 'F' Platoon where he was reunited with several men whom he had served with in Ireland. The training did not seem to be of any challenge to Duff and the other men who had already completed similar training while in Ireland. It was not long until their new uniforms arrived. The reception of their new garb was less than exciting as Duff describes: "We were dressed in khaki serge of a villainous war-time texture, not a single man had his clothes fitting him, whilst we also wore black puttees and a Stetson wide-awake hat with a scarlet and green pugaree, undoubtedly hats that had been made for men of the New Zealand forces..."144 Much in the same way that the Black and Tans had their uniforms cobbled together from a variety of service items from throughout the Empire, the Gendarmerie now found themselves in

\footnotetext{
${ }^{144}$ Duff, Sword for Hire, 94.
} 
a similar position. However, as Duff discovered later, this distinct look carried the same kind of stigma into Palestine. ${ }^{145}$

Leading the men was a Brigadier-General who had served during the First World War in Palestine and took very quickly and consistently to looking down upon his new group of men. ${ }^{146}$ Below him was a senior officer formerly of the RIC who Duff described as being well-liked, had many years of service and was also frustrated by the General's treatment of the recruits. The adjunct was an officer of the Auxiliary who was not well liked. Duff recalled there were desertions every day and a growing frustration among the men who had been doing this sort of work for years. Duff brings up the dissatisfaction of being treated like a serviceman or a 'raw recruit'. There were other circumstances which further alienated the men from the BrigadierGeneral. For instance one rule laid down during their time at Fort Tregantle was that the men were not allowed to leave the fort unless they were in uniform. Duff writes that this did not sit well because the, "men were ashamed of being seen in the ill-fitting, ugly slops that we were forced to wear." ${ }^{147}$ According to Duff most of the men resented being treated like irresponsible private soldiers after already having passed through training and also field experience in Ireland. The training at Fort Tregantle seems to be more aptly described as a drilling of formations and a rehashing of the training the men received in Ireland

Week after week, the men were told that a ship would soon come to take them to Palestine. Finally on April 13, 1922, The City of Oxford arrived to carry the recruits off to a land

\footnotetext{
${ }^{145}$ The Stetson hat was one of the defining visual elements that set the Gendarmerie apart from the Palestine Police who wore the Kalpak.

146 This Brigadier General is almost certainly Angus McNeil. However, McNeil's diaries do not cover the period of training and transition that Duff discusses. Regardless, Duff's resentment of the General comes out quite clearly in much of Duff's writing.

${ }^{147}$ Duff, Sword for Hire, 95.
} 
from which some would not return. ${ }^{148}$ It was a small ship, cramped and unsuited for such a large contingent of men. The circumstances of their transport did little to please those who felt they were being treated like enlisted soldiers rather than civil policemen. Duff describes the men's dismay at their new lodging by writing, "our men were mainly of the officer class, used to fair dealing and some consideration, and many were the angry murmurs when we saw what had been prepared for us." ${ }^{149}$ After several days of poor conditions and continued insult from their Commandant, there was essentially a mutiny aboard the ship. With all of the men brandishing their pistols they took their case to the Commandant where the spokesman of the group said, "May I also say, sir, that we are not troops, we are policemen, and Civil Servants and that we resent being treated as though we were raw recruits. If we are handled properly there will be no finer force in the world than ours, but we cannot stand much more of what we have had ever since we joined." ${ }^{150}$ Following this incident, the leadership relented, and for the most part, Duff claims that the men felt that they were receiving some measure of the respect they deserved. ${ }^{151}$

This incident shows something that became more clear throughout the voyage and also during Duff's time in Palestine; there was a real fear among the men as to whether or not they would be treated as soldiers or as policemen. There are several times throughout Duff's writings when the Gendarmerie was used as a military rather than a police force. It is also clear that the men took issue with these blurred lines. Duff recalled one man speaking about the Commandant, "If that old man has his own way we shall be indistinguishable from a battalion of infantry, but if

\footnotetext{
148 There was some debate in parliament as to whose authority the British Gendarmerie would be under. Some such as Sir Norton-Griffiths thought that the raising of the British Gendarmerie was premature as the Treaty of Sevres was not yet ratified. See HC Deb 04 May 1922 vol 153 cc1540-1

149 Duff, Sword for Hire, 96.

${ }^{150}$ Duff, Sword for Hire, 98.

${ }^{151}$ There is no other account to corroborate Duff's retelling of this voyage. However, this story does seem plausible as it follows the theme consistent in many sources of policemen being treated as soldiers.
} 
No. 2, the Assistant Commandant, is given a say, he will have us doing Constabulary duties."152 The distinction here being that if the Commandant, a man who only had experience leading soldiers as a Brigadier-General is left in command the men will be treated as soldiers. Yet, if the former RIC officer is left in charge, he knew how to implement soldiers in a police setting.

Finally Palestine was within sight. At the end of April, Mount Carmel came into view. ${ }^{153}$ For Duff, thoughts of the Crusaders came to mind. He thought of the great kings and princes who looked upon the same wind swept coasts. ${ }^{154}$ Duff references the Crusades several times throughout his writing. It is clear that he does not see the British Gendarmerie as having the same divine calling as the crusading kings of old. Still, it does seem that Duff sees his time in Palestine as a sort of noble calling. Not necessarily to take and hold the Holy Land, but an expedition to keep the peace in the same manner he saw himself and the other Black and Tans keeping peace in Ireland.

Upon arrival the men were packed into old run-down barracks. The conditions were extremely hot and the sleeping quarters were infested with insects and small animals. Duff was in charge of messing food. The men were always on the verge of mutiny, even among each other. Tensions continue to run high and animosity continued to grow toward their Commandant; especially when he insisted on putting them in compromising positions. The most serious of these situations was a day when the Commandant ordered the men on a parade drill after they had all just received inoculations. According to regulations the men should have been resting. As a result, half of the platoon passed out during the march. ${ }^{155}$ The Commandant's contempt for the

\footnotetext{
152 Duff, Sword for Hire, 103.

${ }^{153}$ Mount Carmel is a coastal range of mountains visible when sailing into the port-city of Haifa, a northern city in the Palestine Mandate.

${ }^{154}$ Duff, Sword for Hire, 101.

155 Duff, Sword for Hire, 105-106.
} 
men clearly came out at this time as well. Duff recalled that he seemed confounded how highly decorated the men were, mostly from their time in World War I. As he writes: "There were dozens of Military Crosses, Distinguished Conduct Medals, Military Medals, a few D.S.O.'s and every other decoration on the breasts of the men in the ranks, but it appeared strange to the worthy 'brass-hat, ${ }^{156}$ to see so many of these decorations on the tunics of men who were, from all appearance, nothing but private soldiers." 157 The various awards did not change the General's opinion of the men. Especially when the men gave evasive and intentionally non-descript answers when asked where they received the medals. It is clear from these incidents that not only did the Commandant wish to make this a platoon of soldiers, but he also felt that these men were little more than mercenaries. Brig. Gen. Angus McNeil did express worry that the Black and Tans infamous reputation would lead to problems. Prior to their arrival he wrote that negative propaganda was already "rife and the smallest incident was ridiculously magnified."158

Despite the General's hope for having a military regiment of his own design, the facilities could not support 'F' Platoon and its men were redistributed. After the dissolution of 'F' Platoon, Duff was sent to No. 5 Company and found himself fortunate to serve under a well-liked officer by the name of Munro as Company Commander, and another agreeable man named ForbesSharp as company officer. Their new quarters were not much better than their former housing. The heat and lack of ventilation led to a great deal of sickness. Several local pubs were closer to the barracks than the nearest source of fresh water. This led to a severe lack of sobriety as Duff describes, "It is not too much to say that there were very few sober men to be found inside the Barracks after seven o'clock in the evening..."159 This excluded men who were on watch. Such

\footnotetext{
156 The "brass-hat" is referring to the Commandant.

157 Duff, Sword for Hire, 106.

158 Angus McNeil, Notes on the British Gendarmerie, 3 January 1923. McNeil Papers, (MECA GB165 - 0197 ).

${ }^{159}$ Duff, Sword for Hire, 111.
} 
men were committed to sobriety by a rigid form of 'Barrack-room Court Martial' where the men themselves policed such behavior.

Their first call to action occurred in July 1922 in Haifa, when a group of Arabs had gathered to protest the Mandate for Palestine. The crowd began to disperse as the order to 'load' and 'take aim' was given. Duff writes about their reputation, “It was quite enough, the Arabs had heard about us and knew what manner of men we were; there had been a great deal of judicious propaganda from District Officers, telling them what our reputation had been in Ireland." ${ }^{160}$ Here we see the first instance where the colonial police actions in Ireland had some kind of effect in Palestine. Where a crowd may have persisted at the threat of fire, this crowd knew that these particular men behind the rifles had a history of violence against civilians. Any threat made by this group had to be taken seriously. This is also the pattern of containing disturbance that occurred throughout the majority of the Mandate years. Large crowds often gathered in protest, most often against Jewish immigration, and the firm, but measured police response diffused the situation, in most cases.

It was during this time that Duff describes Jews moving into Palestine. Everyday more and more makeshift tents and hovels sprang up. With this influx came an increase in highway robberies, and murders. One such instance took place as they served as police escorts to a treasury official along the route to the Government Headquarters in Nablus during which they came under fire from seventy to one-hundred Arabs. They were able to hold off the attack long enough for a detachment of men to ride ahead to Nablus and bring reinforcements. Reflecting upon this and their other duties such as patrolling the Jordan fordes at nighttime, Duff began to realize that their impact in the region had become similar to their impact in Ireland. As he

${ }^{160}$ Duff, Sword for Hire, 112. 
recounts, “...it was not long before the Stetson hat caused as much alarm, and to the law-abiding gave as much sense of security as the dark-green tunic had done in other days in Ireland." 161 This again supports the idea that Duff thought that he and his men were there for a noble cause. It seems that keeping the peace and serving justice did in fact matter to him. In Ireland, Duff thought that they were there to restore order, and again in Palestine the same brand of justice was needed.

Even though it appears that the reputation of the Irish contingent had followed them into the Mandate, the alleged behavior did not. The kind of crime Duff and the Gendarmerie were helping to combat was largely common offenses and immigration control. The remainder of Duff's account regarding the Gendarmerie does not note any serious attacks made against the police, nor does it recount violence against either Jews or Arabs. Also, there were no large-scale uprisings or protests like those seen in the early 1920s. They were not under constant threat from nationalist rebels and thus the ambush/reprisal dynamic that existed in Ireland did not occur in Palestine. From Duff's experience it is clear that there was some continuation of violence, but it did not manifest in the same way that it had in Ireland. The Gendarmes were almost always acting in a manner that worked towards a resolution that would not breed further outrage. Also, the Gendarmerie often only ran into trouble when trying to protect Jewish settlers or dealing with smugglers and criminals. They did not provoke the same outright acts of 'outrage' as the security forces in Ireland. This seems to suggest that the nature of violence in Ireland, while similar, was The fact remains however, the initial fears of the media, and McNeil himself, never materialized.

${ }^{161}$ Duff, Sword For Hire, 111. 
This is all the more important when considering the fact that in 1926 the Gendarmerie was disbanded and its men were absorbed into the Palestine Police.

\section{The Fall of the Gendarmerie, the Rise of the Palestine Police}

Despite the known efficiency of the Gendarmerie, in early 1925 it seemed as though their days were numbered. The Gendarmerie and other security forces may have been too effective in keeping the peace as the British Government could not find a reason to justify having two separate forces in the Gendarmerie and the Palestine Police Force. From April 1925 until February 1926 a discussion continued in Parliament about how to keep down the cost of security forces. In the end the decision was made to disband both the British and Palestine

Gendarmerie. ${ }^{162}$ It was hoped that by introducing this significant group of well-trained Brits into the Palestine Police a kind of 'British discipline' would be instilled.

On April $1^{\text {st }} 1926$ nearly half of the men who were in the British Gendarmerie were absorbed into the British section of the Palestine Police. At the time, the Palestine Police Force consisted of seventy eight officers and 1059 other ranks. With the addition of the Gendarmerie two more officers were added and the force gained the advantage of two-hundred-ninety mounted units as well as twenty-eight foot police. There were however casualties to the merger as Angus McNeil was not given command and made the decision to pass into retirement in Galilee. Meanwhile, those in the Palestine Gendarmerie was transformed into the Trans-Jordan Frontier Force. In this capacity they would continue to be a primarily mounted unit responsible

\footnotetext{
${ }^{162}$ The Palestine Gendarmerie was similar to the British Gendarmerie in its duties. However, the Palestine Gendarmerie consisted of local Arabs and Jews. The extensive knowledge of the region made them well suited to continue on policing the Trans-Jordan border.
} 
for patrolling the border of the mandate. Additionally, they were placed under the authority of the military and thus the War Office. ${ }^{163}$

Moving forward, with the incorporation of the British Gendarmerie the primary concern of the Palestine Police was to keep the peace in the rural areas surrounding the major cities. This task was made more difficult due to the dissolution of the Palestine Gendarmerie. Previously, the Palestine Gendarmerie had been responsible for patrolling the frontier which included borders with Egypt, Trans-Jordan, Lebanon, and Syria. With the Palestine Gendarmerie gone, the task of controlling these rural outskirts, along with the smuggling and illegal immigration problems that came with them, fell to Commandant A.S. Mavrogordato and his Palestine Police. ${ }^{164}$

New responsibilities were not the only challenge facing the force. The new British contingent had to be configured into a system that had already been working quite well. The Palestinian section of the force was already skilled in the traditional law and order duties of the police. Jack Binsley, a constable who joined the Palestine Police Force several years after the dissolution of the Gendarmerie claimed that the local police, "did all the real police work, investigation and prosecution while the British section were primarily for prevention and any military action that should be needed." ${ }^{165} \mathrm{He}$ went on say that the British men were usually charged with keeping the diary of the day's events while, "all crime was referred to the local police and futile entries were made in the dairy..."166 The British section was then seen as a sort

\footnotetext{
${ }^{163}$ Horne, A Job Well Done, 96-97. It is important to note as well that at this time, many of the men that were continuing to come into the force no longer had any affiliation with the Black and Tans, Auxiliaries, or RIC.; The Trans-Jordan Frontier Force were a paramilitary force after the formation under Imperial Service. What is also important to note about the force is that in this capacity their work was not bound by borders. See British Palestine Police Association Magazine, (MECA), Spring 2014, p 15.

${ }^{164}$ After establishing the Palestine Police and leading them for several years, Lt. Col. Bramley relinquished command to A.S. Mavrogordato.

${ }^{165}$ Binsley, Palestine Police Service, 26.; When the term 'local police' is used, it is referring to the Arab and Jewish police.

${ }^{166}$ Binsley, Palestine Police Service, 26.
} 
of 'rough and tumble' group that could be used for riot control. Horne writes that they, "applied themselves to the serious business of mastering weaponry, drill and dealing with violent crowds. They hardly touched training in law or police duty but instead considered the quickest way to reach a scene of trouble on a 'fire brigade' basis." 167 It is this lack of training, as well as a lack of knowledge of the locality that seems to be the reason for the 'division of labor' amongst that British and local constables. As Constable J.E. Davies recalled of the manner in which the force was distributed,

The Main body of the British Section was stationed at Mount Scopus, Jerusalem, and detachments of about thirty rank and file in the districts as follows:--At Haifa, which would deal with emergencies up to the northern frontier. The men were billeted at Bat Galim. At Nablus, for the region of Samaria, these men were billeted in the old Turkish Fort: and at Sarafand until 1927 when the men were moved into Jaffa, which would deal with all emergencies from just north of Tel Aviv down to Rafa'a on the Egyptian border. But in the event of serious trouble, local District Headquarters could be reinforced with men from Mount Scopus. ${ }^{168}$

Wishing to make his men into more than just a riot squad, the Commander of the British Section Major J. Munro sought to establish a training program aimed at making real policemen out of the former Gendarmes. Aspects of the program were physically severe and sought to weed out any recruits who were not fit for duty. This was important as there was an increasingly high rate of turnover as the years went on. ${ }^{169}$ Munro forced his men to take larger shares of patrol in the cities and get a feel for what the people were like. This prompted many policemen to take an interest in learning Hebrew or Arabic. ${ }^{170}$

\footnotetext{
${ }^{167}$ Horne, A Job Well Done, 105.

${ }^{168}$ Letter from J.E. Davies to Horne, March $7^{\text {th }} 1970$ quoted in Horne, A Job Well Done, 108.

169 The high rate of turnover seems to come from older members of the force reaching the end of contracts, as well as new recruits encountering a much harsher experiences than they had anticipated.

${ }^{170}$ Horne, A Job Well Done, 109-110.
} 
All of these efforts certainly strengthened the force and brought the British and Palestinians closer together. Still, the training and duties performed by the men seemed to be aimed at preparing them for large-scale uprisings, not common police work. Even to that end, they were ill-prepared for the trials to come. The period of 1926 to 1929 was and would prove to be the most peaceful years of the Palestine Mandate's history. The Palestine Police took advantage of that time to hone their skills as real policemen, while still maintaining the ability to handle a 'real emergency'. ${ }^{171}$ This skill in particular, as will be shown in the next section, would be most useful in the force's immediate future.

As it has been shown, upon arrival into the Mandate the situation into which the British Gendarmerie were placed was an unenviable one. Their former work as The Black and Tans and Auxiliaries earned them a reputation for brutal tactics and bad behavior. Many wondered if this same brand of policing was going to be exported to Palestine. Also, these men were entering into a battle between competing nationalist and religious goals. Jewish immigrants were flooding into the Mandate, and Arabs living in the region perceived the threat of being pushed into an economic and territorial periphery.

Despite the challenges facing the British Gendarmerie, they managed, to some extent, to overcome them. Their bloody reputation of Ireland did not follow them very far into the Mandate. In fact, the Irish security forces' time in the Palestine Mandate led to the most peaceful years of the Mandate's history. This chapter has charted the transition of the security forces from Ireland into the Palestine Mandate. It has examined the situation in the Middle East during and

\footnotetext{
${ }^{171}$ The phrase 'real policemen' is referring to the British contingent of the Palestine Police growing to take part in detection, investigation, apprehension, and prosecution of criminals.
} 
after the First World War as it pertains to the Palestine Mandate. It has also offered an account of policing in the Mandate including: the establishment of the Palestine Police, the recruitment of the Irish security forces into the British Gendarmerie, and finally their training and activities during the Mandate, Lastly, an account of the disbanding of the British Gendarmerie and absorption into the Palestine Police has been discussed an analyzed. This has all been done to demonstrate how the security forces from Ireland evolved beyond the violent tactics that were implemented prior to their transition into the Mandate.

Certainly the case can be made that some violence was used to keep control of region. However, what set the British Gendarmerie and eventually the Palestine Police apart from the security forces from Ireland was a commitment to augment their training. Especially near the end of the decade when Major Munro began to implement new training programs aimed at integrating the Brits into the community and making them more familiar with the duties of a traditional policeman. 


\section{Chapter III: The Palestine Police: Revolt and Reform}

With the incorporation of the British Gendarmerie into the Palestine Police, the force became a more formidable and competent entity. However, the decade of relative calm that the security forces had enjoyed was about to end. Nationalist tensions, which had been building for years were on a collision course. Of course, these tensions were not just rooted in ideas of nationalism, but also by religious fervor, inflamed by leaders such as the Grand Mufti, Haj Amin Husseini. What this all meant for the Palestine Police was a time when the effectiveness of the force was put to the test.

It is the argument of this chapter that the 1930s represent a time when the Palestine Police faced a number of new threats and challenges to which they responded effectively. Starting in 1929 with the Wailing Wall Incident, the force experienced a period of 'riot and reform'. Put simply, the force was faced to three significant trials throughout the decade: the 1929 Massacre, the 1933 Riots, and finally the Arab Revolt of 1936-1939. In each case the force was tested to retain control and each case saw a successively increased measure of success. Regardless, following each incident, there came a time of reform whereby the force attempted to adapt to the ever-changing landscape of threats. By the end of the decade not only was the Palestine Police Force facing threats of insurrection from Arab gangs, but from Jewish gangs as well. ${ }^{172}$ To support this argument, each incident or period will be discussed and analyzed with a focus on the events the force faced and how it responded after the fact.

\footnotetext{
172 The Jewish and Arab 'gangs' were initially relatively disorganized and disruptions early on in the decade were equally disorganized. However, as the decade progressed, both became increasingly more organized. As such, attacks between Arabs and Jews, as well as against British forces became more organized and deadly.
} 


\section{Riot of 1929}

What some refer to as the 1929 Massacres, also known as the Arab Riot of 1929, and the Wailing Wall Incident, were the first major 'battle' that the Palestine Police faced and marks the beginning of a period of ever-increasing violence in the region. Centered around the continuing dispute between Arabs and Jews over rights to the Western Wall, the riots resulted in violent Arab attacks on Jews and their property. ${ }^{173}$ Between August $23^{\text {rd }}$ and $29^{\text {th }}$ there was considerable loss of life and injury. While dealing with the violence the Palestine Police received and doled out their fair share of violence. This section attempts to explain the greatest test the Palestine Police had faced up to this point.

The dispute over the Western Wall had been ongoing long before the British assumed responsibility over Palestine. However, throughout the early twentieth century things had remained relatively peaceful. Jews were not permitted to establish any kind of permanent presence at the wall. This meant that starting in 1912, while still under Ottoman rule, Jews were not allowed to bring anything such as chairs or screens to the wall. As Barnet Litvinoff wrote in the forward to a collection of letters by Zionist leader, Chaim Weizmann, "since the days of Turkish rule, the worshippers had been forbidden to erect a screen to bring chairs, and the British authorities had been meticulous in maintaining the status quo." ${ }^{174}$ By preventing Jews from bringing any traditional prayer-related items to the Wall it prevented them from staking any kind

\footnotetext{
${ }^{173}$ The 'Wailing Wall', 'Western Wall', or 'KaKotel HaMa'ariv' as Jews commonly refer to it is the last remnant of the third temple built by King Herod the Great, which was destroyed in 70 AD. It is likely built on top of the western most wall of the temple built by the King of Israel, Solomon. As such the wall is that last remaining connection to the ancient homeland of the Jews. However, the spot is just as important to Muslims. The Wailing Wall is supposedly the spot where the prophet Mohammad ascended into heaven. As such this site is a major point of contention between the two religions. Tom Segev, One Palestine, Complete: Jews and Arabs Under the British Mandate, trans. Ham Watzman (New York: Metropolitan Books, 1999), 301-306.

${ }^{174}$ Barnet Litvinoff in the Forward of, The Letters and Papers of Chaim Weizmann: Volume XIV, Series A, July 1929-October 1930, Gen. Ed. Barnet (Jerusalem: Israel University Press, 1978), xi-xii.
} 
of permanent claim to the Wall. This remained the situation through the First World War and into the mandate period even as more Jewish settlers began to pour into the region. While there were instances throughout the 1920s of Jews bringing chairs and benches for the elderly to sit upon while they prayed, the status quo was held intact.

The Day of Atonement or Yom Kippur fell on September $24^{\text {th }}$ in 1928 . On the $23^{\text {rd }}$ a Jewish rabbi erected a screen at the Wall for the following day's services. This of course angered the Arab population and Douglas Duff, who was stationed in the city, was ordered to remove the screen. Duff managed to convince the District Commissioner to let him speak with the Rabbi Noah, the Beadle of the Wailing Wall, before removing the screen. This Commissioner agreed and accompanied Duff to talk to the Rabbi. Understanding Duff's concern the Rabbi agreed that the screen would have to come down, but could not do anything at the moment because the sun had already set and the traditional feast had begun. Seeking to find an amicable agreement, the Commissioner gave the Rabbi until seven o' clock the next morning to remove the screen. At six o' clock the next morning the Rabbi arrived at Duff's quarters begging for an extension until nine. However, this extension was not in Duff's power to grant and the Rabbi was forced to take his case to the Commissioner. Rabbi Noah returned at 6:30 in the morning with a grant for extension. As Duff writes, "I did not realize the importance of the case, no one did at the time..." 175 Duff dispatched one of his subordinates to see if the screen had been removed, expecting that Rabbi Noah had complied with the order. Yet to Duff's surprise the man returned "a few minutes later, with his tunic hanging in rags and his face scratched and bleeding, saying that he had been attacked by a number of Jewish women, who had prevented him from removing

${ }^{175}$ Duff, Sword for Hire, 250. 
the screen." ${ }^{176}$ Eventually, Duff's men were able to remove the screen, but not without inflaming the crowd of highly religious Jews who saw the image of British Police ripping apart a religious item on one of their highest of holy days. Further, as Duff recounts, “...Arabs by the thousand were beginning to throng into the city, and, ominously enough, they all carried heavy clubs, whilst most had daggers in their waist-cloths." ${ }^{177}$ The situation did not escalate into a full on riot, but it did serve to turn the Jewish population squarely against the security forces, and especially against Duff himself.

There is perhaps one figure who did more than any other to ensure that the peace which had existed between Arabs and Jews for most of the 1920s would not last: The Grand Mufti of Jerusalem, Haj Amin Husseini. ${ }^{178}$ In 1928 he presided over an Islamic Congress held in Jerusalem to discuss the question of the Wailing Wall. The result of this congress was the decision to form groups to defend the Mosque of Omar. This would eventually play a role in 1929 Massacres. ${ }^{179}$ Duff mentions the al-Husseini family and the Grand Mufti while describing the nature of Arab-Jewish relations,

\footnotetext{
${ }^{176}$ Duff, Sword for Hire, 250.

${ }_{177}$ Duff, Sword for Hire, 250.

${ }^{178}$ The Mufti came from a wealthy family, but was not relatively well educated. After serving as a cadet officer during World War I, Husseini served with the Turks between 1919-1920 in the Sherifian Army. He delivered a speech during the Nebi Musa procession in April 1920 which attributed to the incitement of a riot. For this he was sentenced to fifteen years in prison. However, several months into his sentence, he was pardoned by the High Commissioner. Shortly thereafter his brother, the then Mufti of Jerusalem died and Kusseini took his place. "It was due to Haj Amin's efforts that the Arab and Moslem countries were induced to interest themselves in Palestine for he realized that the Palestine Arabs, without the support of their co-religionists, could not hope to combat the Zionist influence." In May 1933 he traveled to Iraq, India, Afghanistan and Iran to collect money to carry out decisions of the Grand Islamic Congress; the establishment of a University and the redemption of Arab lands. Haj Amin again remained behind the scenes until April 1936 after the outbreak of disturbances when he became president of the Arab Higher Committee. The report made by Sir Charles Tegart describes him as an intelligent man of great charm. He was over-cautious and also, "although he is strongly opposed to Zionism he is said to be in favour of an alliance with His Majesty's Government on the lines of the Iraq treaty.” See St. Anthony's College, Oxford, Middle East Center Archive Sir Charles Tegart Papers, GB 165-0281, [Hereafter Tegart Papers GB 165-0281 (MECA)], Haj Amin Husseini: The Mufti Report.

${ }^{179}$ See Haj Amin Husseini: The Mufti Report. Tegart Papers GB 165-0281(MECA) p. 8
} 
Perhaps I had best explain the situation as it was, and is, in Palestine. The native Palestinians are mainly Moslems, followers of the Prophet Mohammed. They are divided, politically, into two parties, the followers of the Husseini factions, headed by the Grand Mufti, Haj Mani Husseini, and those who adhere to the Nashahivi party, whose leader is Ragheb Bey el Nashahibi, for many years Mayor of Jerusalem. The Husseinis are extremists - nationalists - bitterly opposed to both British and Jews. The Nashashibis are, numerically, far stronger and might be called the Moderates, for they are willing to accept an understanding with both Britain and the Zionists. ${ }^{180}$

Christopher Sykes claims that Arab-Jewish relations had been relatively amiable, but, "under the Mufti's influence this was all changed. The enemy was the Jewish people. To be a Jew was in itself an offence. Arab nationalism adopted anti-Semitism on the coarsest European model."181

The events of Yom Kippur served as a prelude to the riots that ensued the following summer. Duff notes the tension at the time between the two events and also the lack of a British imperial presence beyond the Palestine Police: "There was no force in the country. No Imperial troops were to be found in the whole length and breadth of the Holy Land..."182 Duff and other officials knew it was only a matter of time before uncontrollable violence erupted between the two sides. Tensions were high and border forces were doing their best, but could not stop the smuggling of arms into the region. Tensions continued to build until the following summer. Nobody in the high command raised alarm within the British Government about the security problem at hand. The situation was seen as 'under control'. High Commissioner John Chancellor, felt comfortable enough at the time to leave on holiday in June. Commandant Movrogordato, who had presided over the dissolution of the Gendarmeries and lack of military

\footnotetext{
${ }^{180}$ Duff, The Rough With the Smooth, 124.

${ }^{181}$ Christophe Sykes, Crossroads to Israel: 1917-1945, (Bloomington: Indiana University Press, 1965), 155; Pages of this book and correspondence with the author were found in Cafferata's papers. St. Anthony's College, Oxford, Middle East Center Archive Col. Raymond Oswald Papers, GB 165-0044, [Hereafter Cafferata Papers GB 165-0044 (MECA)].

${ }^{182}$ Duff, Sword for Hire, 253.
} 
support in the region, soon followed suit. None have described the situation better than Edward Horne: “...There was to unfold in Palestine a situation worse than any Homeric tragedy with the two principal actors off stage." 183 By the end of summer 1929 things had reached a breaking point.

Duff claims that the Riots of 1929 began with the most innocuous of events; a young boy kicking a ball over a wall. The story goes that in the Mustashfa Quarter of Jerusalem, a Jewish boy accidently kicked a ball over a wall where a young Arab girl was watching her father's tomato crop. The girl hid the ball from the boy under her skirts and refused to give it back. The boy tried to take the ball back and the girl screamed. A group of Arab children ran to the girl's aid and the boy's playmates ran to his. Soon neighbors from the Jewish community and Arabs from the road adjacent to the field were coming to investigate. It wasn't long until a fight broke out. When the dust had settled a young Jewish man's injuries were so severe he was taken to a hospital where he later died. Duff tells us that the next day the young man's countrymen decided to bury him "and stated their intention of carrying the corpse through the Jaffa Gate, down past the Moslem quarters and so to the cemetery at Silwan." Waiting at the gate was a "threatening crowd of Arabs' ready to meet them. This was the beginning of what Duff called 'the Rising'. ${ }^{184}$

Arab crowds began to pour into the city brandishing a number of weapons from stones to automatic pistols. "Within an hour firing was general throughout the Holy City, bombs were thrown, and motor-cars, filled with young town-Arabs armed with automatic pistols, were

\footnotetext{
${ }^{183}$ Horne, A Job Well Done, 131.

${ }^{184}$ Duff's account of the beginning of the 1929 Riots differs slightly from other accounts. However, the differences are minor. In other accounts the young girl who refused to give the ball back was a young boy. Despite this small difference the end result of the incident was the death of the Jewish boy, Abraham Mizrachi. See Horne, A Job Well Done, 134-135; Duff, Sword for Hire, 255.
} 
careering through the streets of Jewish suburbs firing at all passers-by." "185 Duff also recounts perhaps the greatest contributing factor to the 1929 Massacre: rumors. Throughout the two days of bloodshed one of the most common reoccurrences was the propagation of rumors. Word quickly spread that Jews were seizing the 'great Moslem sanctuaries in the Temple area.' This was of course not true, but it was sufficient to provoke young Arabs from surrounding villages to storm the city.

While the entire Mandate experienced disturbances on some scale, the city of Hebron played host to perhaps the most gruesome scenes of the massacre. On 17 August 1929 at 9:30 PM Assistant District Superintendent Raymond Cafferata received a message from Jerusalem that a stabbing had occurred and a large-scale disruption could erupt soon. ${ }^{186}$ Despite what was going on in Jerusalem, Cafferata received assurance from Arab leader Sheikh Amin Jabari that things would remain peaceful in Hebron. It was reasonable to think that the Sheikh's word would hold true as Arab-Jewish relations in Hebron were good. As Cafferata's report reads: "The Jewish attitude was that they had lived in Hebron for generations; that they were known to the Arabs well and that they were the best of friends." ${ }^{187}$ Cafferata remained vigilant over the next several days and continued to check in with both Jewish and Arab notables to make sure that no trouble was stirring.

Up to midday Friday the $23^{\text {rd, }}$ the situation remained quiet; however this peaceful morning was not to last much longer. At 1:45 PM, Jerusalem was under attack and the request

\footnotetext{
185 Duff, The Rough with the Smooth, 256.

${ }^{186}$ Raymond Cafferata or 'Caff' as he is often called was a figure most similar to Douglas Duff. He had also served in Ireland in the RIC and signed up immediately for the Gendarmerie in 1922. When the 1929 Riots commenced while Duff was stationed in Jerusalem, Cafferata was serving as Assistant District Superintendent of Police in Hebron, about thirty miles south of Jerusalem.

${ }^{187}$ Report by Mr. R.O. Cafferata, A.D.S.P., Hebron, $23^{\text {rd }}$ and $24^{\text {th }}$ August, 1929. Cafferata Papers GB165-0044 (MECA), Leverarch file 1.
} 
for aid went out from the undermanned Jerusalem post. Two hours later, Cafferata posted constables on the incoming road from Jerusalem to prevent any malcontents from spreading the riot to Hebron. Despite Cafferata's attempts, word began to spread rapidly through the city and many Arabs began to gather and wished to march on Jerusalem. Cafferata's attempts to disperse the crowd and dissuade them from mounting busses to Jerusalem were in vain. The situation quickly grew out of hand as a crowd of seven hundred grew ever more restless and began to attack Jewish property in Hebron. In short order Cafferata gathered his eight mounted units and attempted to rush Jews to safety and disperse the crowds. They were successful in their mission, however an offshoot of the crowd made its way north to the Talmudie School where one Jewish man was stabbed to death and another was wounded. By 6:00 PM the streets of Hebron were again quiet and Cafferata had to figure out how to keep them that way.

The most pressing issue now was to plan for the young Jewish student's funeral. Cafferata knew that it was the funeral of a young Jewish boy that led to the outbreak of violence in Jerusalem and he didn't want that to happen in Hebron. Cafferata told the Rabbi Epstein to make arrangements for the dead student and that the funeral would take place either early in the morning or late at night with a limit of six mourners, in order to reduce the chance of Arab trouble. Further, Cafferata ordered all Jews to stay indoors and away from their windows. Mukhtars of Hebron were ordered to control their own people. ${ }^{188}$ While dealing with the potentially explosive issue of the Jewish funeral, Mukhtars arrived from Dura at 9:00 PM under the false presumption that "Arabs were being slaughtered in Hebron and Jerusalem and that they must come in and fight, that the Mufti wanted them and would fine them unless they did so."189

\footnotetext{
${ }^{188}$ Mukhtars are political leaders within a community or village often chosen to represent the village in official matters.

${ }^{189}$ Report by Mr. R.O. Cafferata, A.D.S.P., Hebron, 23 ${ }^{\text {rd }}$ and $24^{\text {th }}$ August, 1929. Cafferata Papers GB165-0044 (MECA), Leverarch file 1.
} 
Fortunately for Cafferata and the other Palestine Police the Mukhtars had dissuaded the people from running blindly into battle and had come to speak with the police themselves.

Despite the efforts of the Palestine Police, Jewish leaders, and the Arab Mukhtars, inflammatory speeches made by the Mufti and misinformation proved too great and by 8:15 AM the next morning, 24 August' 1929, crowds began to form. Armed with stones, the rioters began to attack Jewish homes and Jewish property. Cafferata brought up all available mounted units from his reserve and armed them with rifles. Several different homes were being attacked and Cafferata attempted to defend one, which the mob had surrounded. He recounts the result: "I did all in my power to protect the two Jews by surrounding them with mounted men but the mob surged round and stoned them to death within two minutes." 190 Cafferata began to shoot into the mob with his revolver until he fell from his horse and was forced to run for the road under a hail of stones. Luckily for Cafferata he was able to make his way to the barracks and the crowds began to disperse and make their way onto busses headed to Jerusalem.

The exodus to Jerusalem meant that much of the violent crowd inhabiting the northern part of Hebron was no longer a threat, however there was still a serious threat to the Jewish population in the southern part of town known as the 'Ghetto'. It was during the battle for this part of Hebron that Cafferata recounts one of the most troubling pieces of information. While in a shoot-out he recalled:

On hearing screams I went up a sort of tunnel passage and saw an Arab in the act of cutting off a child's head with a sword, he had already hit him and was having another cut but on seeing me he tried to aim the stoke at me but missed; he was practically on the muzzle of my rifle. I shot him low in the groin. Behind him was a Jewish woman smothered in blood with a man I recognized as a police constable named Issa Sherrif from Jaffa in mufti. He was standing over the woman with a

\footnotetext{
${ }^{190}$ Report by Mr. R.O. Cafferata, A.D.S.P., Hebron, $23^{\text {rd }}$ and $24^{\text {th }}$ August, 1929. Cafferata Papers GB165-0044
} (MECA), Leverarch file 1. 
dagger in his hand. He saw me and bolted into a room close by and tried to shut me out - shouting (in Arabic) "Your Honour, I am a Policeman". 191

This passage is disturbing first for the brutality shown toward a child, but also for the revelation of police complicity in the crime. The fact that a member of the Palestine Police Force had left his own district and was participating in the riots is something that differs from Duff's experience in Jerusalem, but speaks to the larger problem the force faced in the years to come.

The rioting continued until about 1:00 PM when the crowds began to dissipate. By that point the remaining Jewish population had been moved to secure barracks or were in hiding with Arab friends. ${ }^{192}$ By the end of the day the rioting had subsided throughout the Mandate. British troops arrived the next day including Marines from the HMS Sussex and seven-hundred men from the South Staffordshire Regiment entered in Jaffa and Tel Aviv. ${ }^{193}$ Meanwhile the RAF was patrolling the Syrian border with Brig. Gen. W.G.S. Dobbie in command of British troops to restore order. ${ }^{194}$

As it has already been said, the rumors and incendiary speech propagated by the Grand Mufti certainly served to not only create a conducive environment for insurrection, but also to

\footnotetext{
${ }^{191}$ Report by Mr. R.O. Cafferata, A.D.S.P., Hebron, $23^{\text {rd }}$ and $24^{\text {th }}$ August, 1929. Cafferata Papers Leverarch file 1 GB165-0044 (MECA).

192 The official report of presented of Cafferata has to be understood with special consideration. His hand-written report is part of his personal papers along with the typed report, which was presented to a Royal Commission. However, the typed report was prepared by other elements of the Palestine Police. Alan Saunders wrote, "Dear Cafferata, I enclose a copy of your report as it appears as an enclosure to my general report on the disturbances throughout Palestine. You will note that it differs in many ways from the original, but this was necessary in order that it should conform to the general lines on which, in consultation with Drayton it was agreed that all the enclosures to the main report should be framed." See Letter from Alan Saunders to Raymond Cafferata October, 1929. Caferata Papers, GB165-0044 (MECA), Leverarch File 1. However, after comparing the two copies it appears that the changes that were made were largely superficial. Duff also writes of Cafferata's exploits and the countless tales of Arab brutality. See Douglas Duff, The Rough With the Smooth, 258.

${ }^{193}$ The Liverpool Echo, Thursday August 291929.

${ }^{194}$ The Liverpool Echo, Thursday August 291929.
} 
support its continuation once it had started. However, Douglas Duff claims in his memoir another contributing factor as to why Hebron played host to such ghastly scenes,

Most of the surrounding countryside was in debt to the Hebron Jewish merchants, and as soon as they had been slaughtered, their officers and houses were pillaged, and all promissory-notes and ledgers were burnt... ${ }^{195}$

Cafferata made no such claim either in his official report or in his private notes, however Duff's claim would explain the particularly brutal nature of the Hebron massacre.

In the aftermath of the massacre Raymond Cafferata emerged as a hero. In a number of British newspapers he was hailed as, 'The Man of Lead' ${ }^{196}$ These articles claimed he was unaided in the defense of Jewish lives, with the exception of the Daily Courier, which hit closer to the truth by writing, 'almost unaided'. ${ }^{197}$ Still, Cafferata's story is rather exceptional and for his service to the Jewish community his name was inscribed in the Golden Book of the Jewish National Fund. In this book are enrolled the names of people who have been distinguished by their acts for the cause of Zionism. ${ }^{198}$

By the end of August, the total number of dead was set at one-hundred eighty-six. Meanwhile, the number of those in Palestine who were not mortally wounded reached threehundred-fifteen. The following table gives the total breakdown of casualties as they were reported to the House of Commons.

\footnotetext{
${ }^{195}$ Report by Mr. R.O. Cafferata, A.D.S.P., Hebron, $23^{\text {rd }}$ and $24^{\text {th }}$ August, 1929. Cafferata Papers Leverarch file 1 GB165-0044 (MECA).

${ }^{196}$ Liverpool Post and Mercury, Saturday 31 '29

${ }^{197}$ The Daily Courier, Friday Aug 30 '29. Cafferata's scrapbook contains a number of newspaper clippings from several different outlets. The articles all recount Cafferata's heroism in attempting to save Jewish lives. See Evening Express, Friday, August 30, 1929; The Daily News and Westminster Gazette, Saturday, August 21, 1929; The Irish Times, Saturday, August 31, 1929

${ }^{198}$ The Daily Express, Friday, August 30, 1929.
} 
1929 Massacre Casualties

Killed or died of wounds:

$\begin{array}{ll}\text { Moslems } & 83 \\ \text { Christians } & 4 \\ \text { Jews } & 109 \\ \text { Wounded in hospital: } & \\ \text { Moslems } & 122 \\ \text { Christians } & 10 \\ \text { Jews } & 183\end{array}$

Source: HC Deb 06 November 1929 vol 231 cc1018-9

In the wake of the 1929 Massacre, Lord Balfour felt the need to reiterate his declaration for the establishment of a Jewish homeland. The Daily News and Westminster Gazette quoted Balfour as declaring, "The British Empire and all the powers with whom it has been closely associated, have solemnly declared their intention of again rendering Palestine the national home of the Jewish people. See that pledge has been given. Depend upon it, it is not going to be withdrawn." 199 The confirmation of the Balfour Declaration surely seemed like a natural thing to do following the massacre of so many Jews. Further, Chaim Weissman wrote to Balfour after the Massacre stating, "I should greatly appreciate if Your Excellency would kindly convey to special constables in Jerusalem our most cordial thanks their devoted services in protection of Jewish population." 200 However, this did little to quell the anger of an Arab population which was

\footnotetext{
199 The Daily News and Westminster Gazette, Saturday, August 21, 1929

${ }^{200}$ Letter 71, To Sir John Chancellor, Jerusalem. 29 September 1929, English:T.:Or. Copy. W.A. in The Letters and Papers of Chaim Weizmann: Volume XIV, Series A, July 1929-October 1930, Barnet Litvinoff, Gen. Ed. (Jerusalem: Israel University Press, 1978), 57.
} 
spurred to action over growing religious tension and the British Government's insistence on not controlling the influx of Jewish immigrants.

For the Palestine Police the 1929 Massacre revealed all of their glaring inadequacies. While considerable and commendable efforts were made throughout the latter half of the 1920s to adapt to the ever-shifting sands within the Mandate, the events of late August proved too great for anyone to anticipate. The British and Palestine governments had grown complacent in the years of peace and thus allowed for the two errors which enabled the massacre to take place: an inadequate garrison of military troops and a faltering numbers within the Palestine Police Force. The Palestine Police had seen a significant drop in recruitment in the years following the dissolution of the British Gendarmerie and with the years of peace, no real effort had been made to bring their numbers up. Finally, when trouble did begin and the force was overwhelmed, there was no military garrison to call upon for support. Over the next several years the Government and the Police performed a serious overhaul of how it planned to secure the Holy Land. This reform could not be performed fast enough as the next serious test of the Palestine Police was only three short years away.

\section{Post-1929 Reform}

Following the Riots of 1929 it was clear to both the British and Palestine Governments that the problems of Jewish immigration and the rise of Arab nationalism could not be ignored. Also, there were questions surrounding the effectiveness of the Palestine Police Force. As debates from the House of Commons show, both the money being spent on security, as well as the inadequate number of constables was partially to blame. MP, Lt.-Commander Joseph Kenworthy went so far as to ask: "Is it not a fact that no troops would have been required if the 
late Government had not reduced the police forces?"201 This is a matter for debate, but what is clear is that spending had gone from $£ 834,319$ in 1924 to $£ 244,374$ in $1928 .{ }^{202}$ This drop in spending may have been sufficient for the halcyon days of the 1920s, but for the wars to come such a meager budget would simply not do. ${ }^{203}$

The Shaw Commission, headed by Sir Walter Shaw was assembled to investigate the massacre of August 1929. The commission's findings were released in March of 1930 and suggested that the massacre was the latent result of British policy toward Jewish immigration after the First World War. The uninhibited influx of Jews into the region only served to continually strain relations between Jews, Arabs, and the British. ${ }^{204}$ Coupled with a rise in Arab nationalism, the Western Wall incident served only as a spark to set off the powder keg. The Shaw Commission gave way to a second report by Sir John Hope Simpson known as The Report on Immigration, Land Settlement and Development. This report made the recommendation that Jewish immigration into the Mandate be halted. Hope Simpson came to that conclusion by presenting the negative impact land development initiated by the Jewish National Fund had on Arabs. ${ }^{205}$ Hope Simpson saw Arab exclusion from economic and agricultural opportunities in

\footnotetext{
${ }^{201}$ HC Deb 05 November 1929 vol 231 c828

${ }^{202}$ HC Deb 01 November 1929 vol 231 cc $485-6 \mathrm{~W}$

${ }^{203}$ In Parliament the force report for the Palestine Police was as follows, "Jews, 211; Arabs (including all nonBritish Christians), 1,120. For the Trans-Jordan frontier force: Jews, 27; Arabs, 441. The latter force, while available for service in both Palestine and Trans-Jordan, operates mainly in Trans-Jordan, to which the Balfour Declaration did not apply. See HC Deb 01 November 1929 vol 231 cc485-6W

${ }^{204}$ To give some perspective on how the rate of immigration progressed, it is estimated that in the 1880s Jews comprised about 6 percent of the population of Palestine under Ottoman rule. This number rising to about 8 percent in 1918, 18 percent in 1931 and 31 percent in 1939. See, "British Mandate Over Palestine," Global Perspectives, last modified 2002. http://www.cotf.edu/earthinfo/meast/israel/IPtopic2.html.

${ }^{205}$ Chaim Weizmann argued in a letter to Lloyd George that the problem was not Jewish immigration, but British administration: "The general trend of the Report is to suggest that there is no room for additional population in Palestine. We have worked in that country for the past fifty years. We have sent to it more than one hundred thousand men and women, and millions of pounds; we know every stone and clod of it; and we declare that any statement that Palestine is an overcrowded country is untrue, and that provided our work is not hampered, or rendered downright impossible, by obstruction and sabotage, we shall be able to put at least 50,000 additional families on the land, without the least injustice to its present occupants." See Letter 228, To David Lloyd George, London, 27 March 1930, English: Or. Copy. T.W.:W.A, in: The Letters and Papers of Chaim Weizmann: Volume
} 
the region as a primary cause for widespread unrest. The solution, according to the report, was to limit Jewish immigration into Palestine. ${ }^{206}$

These reports are important for two reasons; first, they offer an accurate analysis of the situation within the Mandate. Throughout the 1920s, tensions simmered beneath the surface, but the security forces were able to manage them. Following the dissolution of the British Gendarmerie, Jewish immigration continued to rise and so too did Jewish-Arab tensions. Jewish immigrants and The Jewish National Fund began to purchase land at an ever increasing rate, thus pushing many Arabs into an economic periphery. The second important outcome of these reports was a reconceptualization of the Palestine Police. Both reports suggested that the composition and duties of the police were hindering them from keeping the peace. The Hope Simpson Report made the argument that immigration and illegal immigration control both fell under the responsibility of the police. This was reported to be too much for the security forces to handle on top of their other duties. ${ }^{207}$ Meanwhile, the Shaw Commission suggested that British officers of the Palestine Police were the only ones who kept the 1929 Massacre under any kind of control and Palestinian officers failed to do their duty because of religious and political sentiments. ${ }^{208}$

Perhaps the most important result of all of this, as far as the police were concerned, was the involvement of Herbert Dowbiggin. Dowbiggin had previously been Inspector General of Police in Ceylon. He had also been called in to assess police forces elsewhere in the Empire

XIV, Series A, July 1929-October 1930. Barnet Litvinoff, Gen. Ed. (Jerusalem: Israel University Press, 1978) Page, 253-254.

${ }^{206}$ The Hope Simpson Report, "British Palestine Mandate: The Hope-Simpson Report," http://www.jewishvirtuallibrary.org/jsource/History/hope.html (accessed on February 12, 2015).

${ }^{207}$ The Hope Simpson Report

${ }^{208}$ According to accounts from Douglas Duff and Raymond Cafferata, there is some truth to these accusations. However, to say that all of the Jews and Arabs within the Palestine Police failed to do their duty is a generalization that is not entirely accurate. See Report by Mr. R.O. Cafferata, A.D.S.P., Hebron, $23^{\text {rd }}$ and $24^{\text {th }}$ August, 1929. Cafferata Papers Leverarch file 1 GB165-0044 (MECA); Duff, Sword for Hire; Horne, 159. 
including Northern Rhodesia and Cyprus. With Dowbiggin came yet another report. However, this report was specific to the reorganization and improvement of the Palestine Police.

Dowbiggin made very clear what he thought was working and what he thought needed to be changed. Dowbiggin's report called for many modifications within the force including an increase in British Officers, an increase in Arabic/Hebrew literacy for officers, additional Palestinian and British Magistrates, and most importantly to him a new training school at Tel Pioth. These changes represented Dowbiggin's overarching assessment that the police in Palestine were doing the best they could, but were missing key elements to make them a more effective force. One area that Dowbiggin emphasized was the importance of leadership:

The officers themselves must receive constant instruction in order that they may make the instruction of their men progressive. The instruction of the officers must come from the Commandant. The future of the Force depends largely on the officers, both British and Palestinian. During the next twenty years it will depend to a great extent on the British officers. During those twenty years the Palestinian officers will have the benefit of working with the British officers and British police in large numbers and if a sound system of training for both British and Palestinian officers is laid down the Palestinian officers in twenty years' time should be able to stand very much more on their own feet than they are able to do to-day. ${ }^{209}$

Here we see the suggestion that the leadership of the police was inadequate. Dowbiggin considered the Commandant at the time, Mavrogordato, to be a man who possessed abilities commensurate with a subordinate officer or a commanding officer. ${ }^{210}$ However, for all the qualities that Dowbiggin admired in Mavrogordato he thought that he was still lacking in certain areas. For Dowbiggin the Commandant should have, above all else, initiative and vision. This

\footnotetext{
${ }^{209}$ H.L. Dowbiggin, The Dowbiggin Report, (London:Wyman and Sons, Ltd., 1930), p. 249 paragraph 222

${ }^{210}$ Dowbiggin cited Mavrogordato as a talented linguist who had good relationships with the Trans-Jordan Frontier Fore, the Arab Legion, the Police in Syria, Sinai, and Egypt. He thought that Mavgordato was good tempered and apt at controlling a crowd. The Dowbiggin Report, p. 261 paragraph 236.
} 
idea of initiative and vision ties into Dowbiggin's larger notion of the Commandant as a trainer of men. "While his subordinates are carrying out their daily duties, the Officer Commanding must be thinking 'one ahead'. As the main duty of every Police Officer is to prevent crime, so the main duty of the Head of the Force is to prevent trouble." ${ }^{211}$ According to Dowbiggin, the events of August 1929 could have been prevented or mitigated by a commander with greater foresight, moreover he felt Mavrogordato did not have the necessary ability or training to carry out the reforms that were needed.

Jack Binsley has written of this time period in his memoirs. He recalled that "Mavrogordata was a popular jovial socialite who enjoyed life, but who was more concerned about social acceptability than the efficiency of his police force." ${ }^{212}$ To Binsley, the proof of Mavrogordato's inefficiency was in the lack of real police work being done by British constables, as well as "the large number of Britishers leaving the force on completion of their short contract." ${ }^{213}$ For many of these men, the Palestine Police was meant to be their career, but according to Binsley, they had become disillusioned by the lack of interest in their training and welfare. ${ }^{214}$ Mavrogordato had been in command for over nine years and was already due for departure and so the decision was made on May 8, 1931 to replace Mavrogordato with his deputy, Alan Saunders, who served as Acting Commandant until a permanent replacement could be found. ${ }^{215}$ Saunders was relieved on July 16, 1931 by Roy Godfrey Bullen Spicer.

\footnotetext{
211 The Dowbiggin Report, p. 262 paragraph 236

212 Binsley, The Palestine Police, 33.

${ }^{213}$ Binsley, The Palestine Police, 33-34.

${ }^{214}$ Binsley, The Palestine Police, 34.

${ }^{215}$ Horne, A Job Well Done, 163.
} 
Spicer had been Commissioner of Police in Kenya since 1925 and was a protégé of Dowbiggin in Ceylon before that. ${ }^{216} \mathrm{He}$ was a shot of fresh blood into the arm of the Palestine Police. Spicer was described as a hard man with a will of iron. He took to implementing as many of Dowbiggin's suggestions as he could with remarkable zeal. The Palestine Police would no longer resemble the model established by the Gendarmerie, characterized largely as riot controllers. Instead, the police were now charged with mounted patrol and traffic control in addition to being an expert riot squad. This was done in a fashion which promoted integration. Where British and Palestinian officers were kept separate before, Spicer ordered all men to work together. As Horne writes, "it bred a new police spirit in the British section, it stiffened the Palestinian personnel and made them much more resolute and finally it led to a greater understanding between all races in the force and the morale and efficiency of the men rose accordingly." ${ }^{217}$ This step of bringing the different contingents together changed the composition and nature of the police. The likelihood of Arab or Jewish officers being complicit in a crime of their own people was then less likely.

The integration of British, Jewish, and Arab policemen was quite important in the wake of the 1929 Massacre where many of the Palestinian police were seen as unreliable. Spicer sought to bring the force together through forcing men to work and share duties and also incetivizing language proficiency among British constables. Binsley writes of these efforts: "My work was quite interesting and I had some nice Arab police to work with so, rarely speaking English at work, I improved my Arabic to the extent that I was able to pass a higher Arabic

\footnotetext{
${ }^{216}$ Spicer was educated at Colet Court and St. Paul's school before entering the Ceylon Police in 1909. He remained there rising to the rank of Superintendent until 1915 when he was commissioned into the $6^{\text {th }}$ Dragoon Guard during the First World War. Spicer suffered a wound in France and after battling a prolonged illness from a gas attack was awarded the Military Cross in 1918. Horne, A Job Well Done, 163.

${ }^{217}$ Horne, A Job Well Done, 168.
} 
police exam named Regular Arabic." ${ }^{218}$ Binsley goes on to note that knowledge of the native languages was encouraged by periodic examinations in both Arabic and Hebrew, which allowed pay increases. Because of this examination the prospect of making a career in the force now seemed much more attractive and Binsley committed to learning Hebrew on top of Arabic. ${ }^{219}$ This incentive encouraged closer relations among policemen, but also had the added benefit of making British constables more accessible to the people whom they were policing.

Spicer was also dealing with men who were not drawn from former military service. Men now needed more extensive training in the military drill that was already known to exservicemen. Binsley writes of the new civilians recruited that, "they had three months training, needing more drill, musketry and PT. They were also taught police work, some law and a little Arabic, so they had a great advantage over us, who were sent out to do police work with no training." ${ }^{220}$ Having entered the force a little more than a year before these reforms took place, Binsley clearly thought that these new recruits, having received enhanced 'police' training, had an advantage despite their lack of military training. However, the men who had already been trained were also receiving new forms of training. "Our new Inspector General was now making progress in creating a more efficient British Section...We each received a Police Manual, which, in simple form, contained valuable information on what an efficient police constable should know."221

Dowbiggin saw Spicer as the sort of man that was necessary to lead the Palestine Police in their reform and Spicer did indeed possess a vital energy, initiative, and vision which he tried

\footnotetext{
218 Binsley, The Palestine Police, 82.

219 Binsley, The Palestine Police, 49.

${ }^{220}$ Binsley, The Palestine Police, 18.

${ }^{221}$ Binsley, The Palestine Police, 49.
} 
to instill in his own men. As Spicer began to initiate reform, there were still sporadic bouts of violence which were quelled handily by the police. We see the first real proof of improvement in the Annual Administrative Report of 1932. This report was filed after Spicer had been in charge for just over a year and a half and certainly addressed some of the prime issues cited by Dowbiggin. For instance, the faltering numbers were brought up over the course of two years. Although the scheduled force strength was set at 2,332 Spicer was only able to claim 2,306. ${ }^{222}$ Still, this was a great improvement.

When it came to rates of murder in Palestine there was a steady decrease as shown by the following chart:

Murder Rate in Palestine

Year Number of Murders

$1928 \quad 188$

$1929 \quad 178$

$1930 \quad 126$

$1931 \quad 119$

$1932 \quad 119$

Source: R.G. B. Spicer, Annual Administrative Report 1932, in Faraday Papers GB 165-0101, (MECA).

This decrease in murders is considerable given the continued rise in population. Spicer himself was quite satisfied with this outcome:

An increase in crime in this territory must, of necessity, be expected with the growth of population, and with the rapid expansion of the urban areas. The key note to police success in keeping it within a reasonable figure will be, in my opinion, the prevention of its commission by means of intensified application of

\footnotetext{
${ }^{222}$ St. Anthony's College, Oxford, Middle East Center Archive, J.A.M. Faraday Papers, GB 165-0101, [Hereafter Faraday Papers GB 165-0101, (MECA)], Annual Administrative Report 1932 by R.G. B. Spicer.
} 
the patrol system, and close contact with those who have shown themselves to be definitely professional criminals. ${ }^{223}$

Overall, Spicer was quite proud of how his men were responding to the new training programs and new way of doing business. Things seemed to be on the right track in the early 1930s, until that is the 1933 Riots. They serve as the first large-scale instance of violence during Spicer's leadership.

\section{The Riots of 1933}

The 1929 massacre, as has been shown, was an unplanned, disorganized manifestation of growing Arab discontent and agitation propagated by the Grand Mufti. In its aftermath, Arabs grew even more dissatisfied with the immigration of Eastern European Jews into the Holy Land. This was all despite the recommendations made by the Hope Simpson Report to halt Jewish immigration. British mishandling of the situation served only to provoke further violence. As Horne writes, "the British seemed hell bent upon a course of antagonizing Arabs as well as Jews with their curious belief that the two races could be forced to live side by side in one tiny country." 224 Prior to this point, it was not so unreasonable to think that co-habitation was a possibility. For most of the 1920s, events in Palestine were relatively peaceful. The 1929 Massacre, when viewed in conjunction with the attempt at reform made via the various commissions and reports, suggest that Jews and Arabs living together and sharing the Holy Land was a viable option if proper action was taken. Yet, the events of 1933 coupled with British refusal to limit Jewish immigration, placed a peaceful resolution beyond hope for the foreseeable future.

\footnotetext{
${ }^{223}$ R.G. B. Spicer, Annual Administrative Report 1932, in Faraday Papers GB165-0101 (MECA).

${ }^{224}$ Horne, A Job Well Done, 186.
} 
Beginning in the autumn of 1933, Arab leaders became more vocal in their opposition to Jewish immigration and settlement. The primary modes of resistance were columns in local newspapers and protest parades. Obviously the latter made the police more nervous than the former. In October 1933 Arab petition requests were filed to march in protest of Zionist settlement. The Arab petitions were rejected by the Palestine Police which feared that the demonstrations would escalate into full-scale riots. There were small pockets of protest, which sprang up randomly throughout October despite the formal petition rejection. Still, they were easily dispersed by mounted constables and men on foot. These disturbances began in Jerusalem on October $13^{\text {th }}$, yet it was not long before these small pockets began to grow larger and eventually reached a crescendo on Friday the $27^{\text {th }}$ of October 1933 in Nablus, Jaffa, Haifa, and Jerusalem. $^{225}$

The morning began in Jaffa without incident and seemed to be a day like any other. However, sometime before noon the storefronts in the Clock Tower Square began to close and the square stood oddly vacant. Just after mid-day prayers, the streets were flooded by an armed mob. The size of this crowd has been disputed by those present with some estimates being as high as ten thousand and others putting the number between three and four thousand. The Murison Commission, after having reviewed photographic evidence and accounting for the size of the square, estimated that the crowd was around 8,880 strong. ${ }^{226}$ As the crowd entered the square they were met by a line of the Palestine Police standing behind shields with batons

\footnotetext{
${ }^{225}$ Following the events of the 1933 Riots, a commission was appointed by the High Commissioner of Palestine and then published in the Palestine Gazette on $16^{\text {th }}$ November, 1933. The commission that investigated the riot was headed by Sir William Murrison. The report is often cited as 'the Murrison Commission. See Palestine Gazette, Wednesday, $7^{\text {th }}$ February, 1934 in Faraday Papers GB 165-0101 (MECA). Box 2 File 2.

${ }^{226}$ Palestine Gazette, 95.
} 
drawn. ${ }^{227}$ Looming over the line of constables were forty mounted officers. The report cites witnesses recalling the mob as being 'menacing', 'truculent', and 'dangerous'. The District Commissioner, Robert Crosbie, described the armed men holding their weapons above their heads as being a, 'perfect forest of sticks' waving in the air. ${ }^{228}$

J.A.M. Faraday, the Palestine Police officer in command of Jaffa, first attempted to make a peaceful appeal to the crowd and urged, in Arabic, to disperse and return home. When the request to disperse was ignored, Faraday ordered the police to perform a baton charge, whereby they attempted to disperse the crowd by force. The constables on foot proceeded forward, spreading out to open the ranks and allow the mounted units to fill them. Two policemen were stabbed during the first charge and the line was forced to retreat and re-form. The second charge was more successful in pushing the crowd back, but again the police were forced to retreat and re-form. Following the third charge, Faraday made yet another plea to the crowd to disperse. By this point a contingent of Palestine Police armed with rifles were in position. ${ }^{229}$ The 'firing party' was ordered to release a volley after the third baton charge, but this did little to compel the crowd into retreating. As the report goes on to describe the situation:

Then Mr. Faraday (referring to the collapse of the horses already mentioned) called out to the District Commissioner, Mr. Crosbie, 'Horses are not good: only rifles are any good, can I shoot again'? The District Commissioner gave his consent and at the same time the Superintendent of Police, Mr. McConnell, said to Mr. Faraday, 'Hold you fire as long as possible'. ${ }^{230}$

\footnotetext{
${ }^{227}$ The tactic of forming a riot line and arming the Palestine Police with shields and batons is another innovation of Spicer leadership. The new training and protocol for handling riots is demonstrated well in the 1933 Riots.

${ }^{228}$ Palestine Gazette, 95.

${ }^{229}$ The 'firing party' had been kept purposefully out of view so as not to incite violence from the beginning. The report also makes special mention that during the second baton charge there were shots that came from the crowd. See Palestine Gazette, 96.

${ }^{230}$ Palestine Gazette, 96.
} 
Faraday did hold the order for a moment, but then ordered the second volley to be fired into the crowd. Unlike the first volley this one had an effect; the crowd gave way as the police line began to command the flanks of the crowd and push it back into three different streets. The 'firing party' then split into three groups and fired a third volley, pushing the crowd further back into one of the three streets. During this time shots were still being fired from the crowd. Also, a hail of projectiles continued to rain down on the Palestine Police. ${ }^{231}$ Despite the resistance of the crowd, the three volleys fired proved enough to clear the square. All of this occurred between noon and roughly 12:30 PM. As the disturbance in Clock Tower Square seemed to be under control Faraday went to King George's Avenue to check in with another contingent of policemen who had also been able to push back an offshoot of the primary crowd. Upon returning to the square the riot had concluded by $1: 15 \mathrm{PM}^{232}$

In Haifa a similar disturbance took place later in the evening around 7:30 PM. A crowd numbering close to two-thousand was met at the police barracks by a baton line and firing party of four rifles. District Superintendent of Police, Major Foley, like Faraday ordered the immediate dispersion of the crowd in both English and Arabic. As the crowd became more violent, Foley ordered a volley to be fired. The crowd retreated, but immediately returned with a hail of stones and bricks. A second volley effectively dispersed the crowd. The report tells us, "During the charge one British Constable was seriously stabbed in the back. One man who was in the front of the crowd received a bullet wound. From the stones and boulders afterwards found in the police

\footnotetext{
${ }^{231}$ The 'missiles' referred to in the report are basically anything that the mob could pick up and throw. Most of the time this was stones or bricks, but also bottles and other refuse.

232 The protocol instituted by Faraday is consistent with the training implemented by Spicer. The line is formed, charges are made, and if the commanding officer feels that the crowd cannot be dissuaded by use of a baton line then they are given several warnings, in English, Arabic, and Hebrew, to disperse or be fired upon. This same tactic went relatively unchanged until the disbanding of the Palestine Police.
} 
barracks, it was clear that a savage attack had been made." ${ }^{, 233}$ During that night the District Commissioner met with local Arab notables who assured the Commissioner that every effort would be made to halt the violence.

In contrast to the incidents in Jaffa, Haifa, and Nablus which were planned by and instigated by Arab leaders, the disturbance in Jerusalem was, as the report suggests, "mainly fortuitous". Unlike the other cities there was no definite and pre-planned protest march. The $27^{\text {th }}$ was comparatively peaceful even when news of the Jaffa disturbance reached the city. Unruly young men began to enter the city and spread false rumors of crowds being mowed down by machine gun fire. Still, no violence was reported on Friday.

Jaffa was host to the greatest amount of violence, but the violence was confined to the events of Friday October $27^{\text {th }}$. In Haifa, the violence resumed the next morning. Despite the promise of Arab leaders, hostile crowds began to gather in the east. By 8:45 AM a large group of nearly three hundred made their way toward the police barracks. The report claims that British Inspector Mosedale stood "in the doorway of the barracks, pointed a rifle at them and they ran away." ${ }^{234}$ The crowd later returned with twice the number throwing stones at the barracks. After the pleas of six policemen to disperse were ignored, police whistles were blown and orders to disperse were made again. As the crowd began to throw more stones Mosedale ordered two shots be fired at the legs of the crowd. This did nothing to deter it. Two more shots were fired. Still, this did nothing to compel the crowd into retreating. It was not until Foley arrived with a small group of Arab leaders that the crowd was convinced to retreat. Throughout the rest of the day, attacks were made upon several Jews in the city, and small groups of Arabs roamed the street.

${ }^{233}$ Palestine Gazette, 99.

${ }^{234}$ Palestine Gazette, 100. 
Aside from the attacks on Jews, there were no other incidents on Saturday the $28^{\text {th }}$. However, small incidents sprang up through Tuesday the $31^{\text {st }} \cdot 235$

At the same time Mosedale was facing the barracks crowd in Haifa, Inspector of Police Muhd Saadi was confronted by a crowd of one-hundred-fifty at Herod's Gate in Jerusalem. Saadi fired into the crowd as they advanced upon him. The crowd began to launch stones at the Inspector until a police-tender with fifteen armed policemen arrived on the scene and dispersed the crowd. The following day a large crowd mustered at the Jerusalem Mosque shortly after noon. The crowd grew in number as half traveled toward the Damascus Gate while half made its way toward the Jaffa Gate. ${ }^{236}$ The three policemen at the Damascus Gate, one of whom was Major Monroe, fired a total of four shots into the advancing crowd until it dispersed. Meanwhile, a crowd of eight hundred advanced on the Jaffa Gate and the two police constables Reginald Mott and Abdulla Zahar. The crowd fell upon Mott and Zahar while the two blew their whistles and attempted to fight off the crowd with the butt of their rifles. Mott was knocked to the ground and was begin dragged back toward the Mosque. According to the report, Mott called out to Zahar to fire into the crowd. Each man (Mott still had possession of his rifle) fired two shots into the crowd. The crowd continued on until Mott fired three more shots into the crowd. Aside from several rioters throwing stones at the police station this marked the end of the Jerusalem disturbance. ${ }^{237}$

\footnotetext{
${ }^{235}$ Several hours later, spurred on by the events in Jaffa a similar disturbance began in Nablus around 4:30 PM on the $27^{\text {th }}$. While this incident shares a profile similar to the others, it was on a significantly smaller scale. There were some minor injuries, but no deaths. See Palestine Gazette, 100-101.

236 Palestine Gazette, 102.

237 The report admits for the Jaffa Gate incident that the only witness statements available were those of Mott and Zahar. However, as no deaths were reported from the incident it is likely that the report is reliable. See Palestine Gazette, 103.
} 
When the dust had settled after several days of protest twenty-seven were dead and twohundred-forty-three were injured. Of the dead, one police officer was killed by a thrown rock and twenty-six citizens were killed as a result of gunfire. Among the injured fifty-six were policemen; three of when were seriously stabbed. Meanwhile, seventy-three citizens were seriously injured by gunfire. The remainder of the injured citizens suffered only minor wounds. 238

The commission concluded that it was clear from all the witnesses it had interviewed that the cause of the disturbances was the result of the Arab Executive calling upon Arabs to hold demonstrations to protest against the policy of the British and Palestine Governments toward Jewish immigration. Further, they concluded that the first outbreak of disturbances in Haifa and that at Nablus were the direct result of the disturbances in Jaffa. As far as the behavior of the police during the riots, it was the opinion of the Murrison Commission that the Palestine Police showed "great restraint" when attempting to disperse the crowds. Foley and Faraday in particular received high praise for their capable command. Spicer affirmed this praise years later when writing about Faraday:

In regard to the serious riots which took place at Jaffa in 1933, I can conscientiously stat that I attribute to his leadership the prompt and entirely successful manner in which this embryo revolt was stamped out. His gallantry on this occasion was remarkable and throughout the 48 hours of bloodshed and riot, he entirely disregarded his own personal safety, setting an example to all ranks of the force, both British, Arab and Jew, which had an exhilarating effect on all of them. ${ }^{239}$

\footnotetext{
238 Palestine Gazette, 104.

${ }^{239}$ Letter from R.G.B. Spicer to the Isle of Wight Constabulary $16^{\text {th }}$ June 1941, Faraday Papers GB $165-0101$ (MECA), Box 2 File 2.
} 
The 1933 Riots were over and the Palestine Police had come through the ordeal vindicated. The improvements made over the previous years were largely seen as a success. While the riots had their share of casualties, they were handled effectively by the Police Force without resorting to military intervention. In accordance with recommendations made by the Dowbiggin Report, small garrisons of military personnel were placed throughout Palestine to be called upon in the case of insurrection. These garrisons were placed on alert during the riots, but were never called into action. The plan seemed to work perfectly.

Still, the tactics used by the Palestine Police can be seen as much more aggressive. With the introduction of 'firing squads' and the more formalized use of firearms the character of the police seemed to be changing. Until this point the men were certainly familiar with the use of rifles and revolvers, yet from the end of the 1929 Massacre on we see an unending escalation of violent tactics between the Palestine Police and the unruly segments of the population.

The next three years passed without another major incident. The Palestine Police had shown that it could handle a large-scale disturbances, but that did not mean Spicer was satisfied. He continued to try and implement more reforms and hone the training of his men. Being a man of "vision" he was trying to anticipate what problems the future held. However, no matter how innovative he was, he could not anticipate how bad things would become. He certainly could not anticipate a world war, and he certainly could not 
anticipate the reactions Jews, who many of his men had died to protect. Ironically, it was

Jews rather than Arabs who would eventually become the greatest threat to life. ${ }^{240}$

\section{The Arab Revolt 1936-1939}

The Arab Revolt represents the most serious escalation of violence in the Mandate. Arab discontent over the continued Jewish quest to establish a permanent homeland began to move beyond the means of conventional diplomacy. In much the same way that Irish republicans lost faith in constitutional attempts to achieve Home Rule, Arab contingents felt that violence was the only viable course of action. In this section the origins of this revolt and how the Palestine Police experienced it shall be discussed and analyzed. The two major consequences of the Arab Rebellion were the formation of Jewish gangs, and yet another period of police reform.

As is so often the case in the eruption of large-scale violence, the origins of the Arab Rebellion stem from a small, seemingly unrelated incident. On 15 April 1936 two Jews were assaulted and killed on the road connecting Tulkarm and Nablus. The guilty party was an Arab gang of bandits with no political or religious agenda to speak of. Regardless, the murder of two innocent Jews was sure to provoke some kind of violent retribution from the Jewish community. The funeral for the two Jews, held in Tel Aviv, served as a stage for an anti-Arab demonstrations. Horne observed that funerals in Palestine "can be the bane of policemen. It gives the opportunity for emotive Semites of both races to bitterly harangue the wickedness of the other party, to the absolute exclusion of all reason."241 This proved to be the case in Tel Aviv

\footnotetext{
${ }^{240}$ The three years between the 1933 Riots and the Arab Revolt seem to be relatively similar in terms of the training of the Palestine Police. Letter written home by Tom Eddison, a constable who joined the force during these years, read very much like those of Binsley. All the aspects of training that Spicer had implemented were still being used. See, Penelope Wilkins ed., Letters Home: From Leslie Herbert (Tom) Eddison D.F.C. To His Family at Yamba, Cotter Road, Federal Capital Territory, Austrailia, Palestine Police 1934 - 1936, Royal Air Force 1936- 1941. (Australia: Penelope Wilkins, 2001).

${ }^{241}$ Horne, A Job Well Done, 207.
} 
where several Arabs found themselves the focus of physical and verbal attacks. Although the Arabs were relatively unharmed, rumor spread to neighboring cities that they had been killed at the funeral. This led to yet another round of reprisal with Arab gangs attacking groups of Jews resulting in three deaths.

Learning from previous incidents, the government took swift action by imposing a curfew in Jaffa and Tel Aviv. Further, the Emergency Regulations of 1936, as well as the Palestine Defense Order in Council were enacted. These allowed the government, police, and military to take extra measures to prevent wide-spread rioting. Crowds that began to form were quickly and peacefully dispersed by the police, as well as the small units of army troops placed in each city under the recommendations made by the Dowbiggin Report. ${ }^{242}$ Tom Eddison, who was in the last few months of his contract, recalled that when dispersing the minor demonstrations, "the District Officers asked the people if they were inabsut min el police, i.e. pleased with us as they say, they reply 'Oh yes, they are very good. They did not attack us or anything.' Actually we get on very well with them." ${ }^{243}$ Coupled with the curfew things remained, for the moment, quiet.

During this period of calm, Arab leaders met in Nablus to form the 'National Committee' and discuss what could be done to combat the continuation of Jewish immigration and lack of interest on behalf of the British Government in changing the status quo of immigration policy. The committee decided on a general strike of all Arabs until their demands were met. The decision of the National Committee led to the formation of subordinate committees in other

\footnotetext{
${ }^{242}$ During this time, Binley wrote about the uneasy nature of things: "Perhaps rather foolishly I continued to patrol hostile areas alone with my Arab constables, but no attempt was made on my life. To try to suppress the revolt, the British Government increased the military, who sometimes operated in the area, but with never less than a hundred men." See, Binsley, Palestine Police Service, 97.

${ }^{243}$ Letter 40, to father, Palestine Police, British Police Gaza 27/4/ 1936. Eddison, Letters Home, 57-58.
} 
cities. With the cooperation of these committees a 'Supreme Arab Committee' was put together by the Mufti of Jerusalem on April 25 $5^{\text {th }}, 1936$ and sought to galvanize all of the individual efforts being made. Three days prior the National Committee called for a strike of all Arab workers. The decision was supported by the Supreme Arab Committee, demanding a halt to Jewish immigration as well as an end to the transfer of Arab lands to Jews. Tom Eddison recalls this period:
All the Arabs here are on strike now as a result of the recent riots. They are protesting about Jewish immigration. In Gaza every shop in the suks is closed, even the coffee houses. There is a curfew in the town now, and every night a patrol goes out to catch people outside. Usually just about curfew time a bomb goes off somewhere near at 9p.m. (curfew time). Last night there wasn't one and we have decided to protest the strike committee for keeping us out of the canteen unnecessarily. It is quite a joke the regular 'time signal'. ${ }^{244}$

The timing of this strike could not have been worse for the British government as 4,500 Jewish immigrants were approved to enter Palestine on May $18^{\text {th }}$. For the entire month, all Arab labor and industry remained at a standstill.

Summer wore on, and the strike continued. However, the temporary peace began to wear thin. Armed gangs began to attack anyone and everyone who stood opposed to them. As Horne described the situation: "these attacks were many and the security forces suffered simply because they were there. Jews suffered simply because they were Jews; but many Arabs suffered also, because they either worked for the government, or for some reason refused to strike."245 In a way that seems to mirror IRA attacks on security forces in Ireland, police in Palestine now found themselves the target of Arab violence. On 28 May 1936 Constable Robert Bird was followed down an alley by four Arab men and shot to death. In a letter to Edward Horne, a former

\footnotetext{
${ }^{244}$ Letter 43, Palestine Police, British Police, Gaza, 9/6/1936. Eddison, Letters Home, 61.

${ }^{245}$ Horne, A Job Well Done, 211.
} 
constable claimed that the assassination of Bird did more than anything else to band the police together into a more cautious and watchful force. The Palestine Police had to fear more than just death in the line of duty. Outright assassination quickly became a reality of the job. ${ }^{246}$

Despite this danger the Mandate was still in need of new recruits. The natural turnover of the force required a constant influx of young men who were eager to find adventure. One such man, Stephen Edwards, joined not long after the beginning of the Arab Rebellion on 14 November

1936. Edwards recounts that he was drawn to the force by a recruiting poster which read:

The Palestine Police offers excellent prospects for men of good character, energy and intelligence who are keen to succeed in an important and very interesting profession...During the last two years over 300 promotions to the inspectorate have been made with corresponding promotions from the ranks to N.C.O...Here is a fine opportunity for a man both to benefit himself and at the same time to perform valuable service for his country in one of the most responsible and vital jobs in the British Empire. $^{247}$

Upon arrival in Palestine, Edwards was put through the end result of Inspector General Spicer's labors. The men were first put through training in the Police Mobile Force to reinforce district police. This allowed them to familiarize themselves with the area while not being directly in the 'line of fire'. ${ }^{248}$ Then they were passed into the Training Depot at Jerusalem where they received further instruction in criminal law, language, and other police duties. ${ }^{249}$

\footnotetext{
${ }^{246}$ Horne, A Job Well Done, 212.

${ }^{247}$ St. Anthony's College, Oxford, Middle East Center Archive, Mark Edwards Papers, GB 165-0354, [Hereafter Edwards Papers GB 165-0354 (MECA)], Recruitment document.

248 The Police Mobile Force or the PMF is seen as one of the crowning achievements of the reforms that took place in the 1930s. The PMF allowed for rapid response, but more than anything it aided in the training of raw recruits. By acclimating them to the region and allowing them to see what the people were like before they were forced to police them, the men were able to place their later training into context.

${ }^{249}$ Palestine Police: Notes for the Information of Candidates for Appointment as British Police Constables, Edwards Papers, GB165-0354 (MECA).
} 
From the training that the Palestine Police received it appeared that they were not being prepared to wage war. However, as in earlier episodes, it seems that their duties began to take on an increasingly militaristic character. Whether the Palestine Police disagreed with how they were being implemented, undoubtedly their day-to-day police duties, especially during the Arab Revolt, look more like the duties of an occupying force rather than a security force. For example, everyday patrols were a perilous activity. When driving through the streets, gangs often erected road-blocks just around the corner of patrol lanes. This presented the perfect opportunity for the gangs to ambush the patrols. The officers on patrol had few options but to attempt to clear the road-block while under fire. The only thing to protect the men while trying to clear the road was covering fire from the Lewis gun that was equipped on each armored car. These types of ambushes were very common not just in urban areas, but also in rural areas where the police would often have to serve as escorts to government officials or supply convoys attempting to prop up the region during the ongoing strike. Eddison describes the prospect of trouble and the anxiety of waiting for it to happen:

Today there is a 'stand to'. Everyone is ready to dash out at a minute's notice. Fully armed. Saddles, batons, rifles are all where we can grab them and leave on the double. The machine gun team is mucking round the gun turret. All this over a general Arab strike all over Palestine...The other day half a million rounds of ammo and Lord knows how many new rifles were seized at Jaffa. They come from Belgium in barrels of cement and were for a Jew. The Arabs say the Jews are arming and will attack them and that it is all the fault of the British. We know that both lots are bringing in arms but you can't search every receptacle that comes into the country. Three frontiers are land ones. The land the other side is half civilized and arms can come in anywhere. A cop only covers as much ground as his feet do. There is not much likelihood of trouble in Gaza as there are no Jews. Perhaps if news came through that Arabs had been killed in Jaffa or Jerusalem or somewhere in a fight, things might start. ${ }^{250}$

${ }^{250}$ Letter 25, to Pam, Palestine Police, Police Headquarters, Gaza. 27/10/1935. Page 38. 
Violence continued throughout the rest of the summer and into the autumn of 1936 until there was a significant lull starting in January and lasting through July 1937. This lull extended to attacks upon the Palestine Police themselves. Meanwhile, Arab terrorists continued to make sporadic attacks against Jews and Jewish property. ${ }^{251}$ The nature of 'terrorist activities' is explained by Tegart:

During the rebellion of 1936 terrorism was intensive and widespread, every part of the country being affected by it in one way or another. In 1937 it was not so widespread, but from time to time outrages of the most brutal nature were committed in different parts of the country. The terrorist campaign in 1937 was accompanied, particularly in the last quarter, by a campaign of sabotage mainly of telephone and railway lines. ${ }^{252}$

When reporting to the House of Commons in July, the Secretary of State for the Colonies, William Ormsby-Gore cited that since May eighty-six Arabs, four Christians, thirtyeight Jews, three police officers and four soldiers had been killed in Palestine. Later in the month he informed the Commons that the strike and the situation in Palestine in general had not changed. MP William Gallacher asked Ormsby-Gore if he was aware that British policemen were protesting against the attempt to use them as soldiers and that a number were sent home under arrest from Haifa because of such protests. Ormsby-Gore replied that,

the duties of the Palestine Police Force, which is an armed force, are prescribed by various Ordinances, by regulations made thereunder, and by special regulations made by the High Commissioner, since the outbreak of the disturbances, under the Palestine Defense Order in Council. I am not aware of any such protest as that referred to in the second part of the question. ${ }^{253}$

\footnotetext{
${ }^{251}$ It is at this point that a conscious decision has been made to refer to the 'Arab gangs' as terrorists. The evidence begins to show Arab attacks targeting non-combatant Jews, especially women and children. Although less organized than the 'terrorist gangs' of the Jews, the actions of the Arabs certainly warrant the branding of 'terrorist'. Horne, A Job Well Done, 220-222.

252 Terrorism-1936-1937, Tegart Papers, GB165-0281 (MECA), p. 1.

${ }^{253}$ HC Deb. 22 July 1936 Series 5 Vol. 315
} 
It is unclear where Gallacher was receiving his information, however it is likely that there were some within the Palestine Police who did not wish to be used in such a manner. There are no personal memoirs of this particular time period which exhibit police protests to being conflated with soldiers. However, The Palestine Defense Order in Council of 1931, which were evoked on April 19, 1936 did give the police powers that resembled those of the military nature. Binsley recalled that during this period, "the whole country was in turmoil. The Arab terrorists increased, defied the government, the military and attacked Jewish settlements and government communications...Trains were mined and derailed, telephone and power lines destroyed, roads ambushed, and several British Police were killed...A state of emergency was declared and military courts were empowered to try offences under this law." ${ }^{254}$ The Inspector General of Police and by extension the police were given permission to take possession of any premises or property that they deemed necessary. Also, any person who discharged a firearm, threw a bomb, or hindered the effort of His Majesty's armed forces or the Palestine Police was subject to the death penalty or life in prison. This sentence was also open to those who tampered with any piece of infrastructure or attempted to damage any ship or aircraft. ${ }^{255}$

Following the assassination of Galilee District Commissioner L.Y. Andrews and his bodyguard Constable McEwan on September $26^{\text {th }} 1937$, five prominent Arab leaders were arrested and deported on October $1^{\text {st }} .{ }^{256}$ Along with the deportations, the Arab Higher

\footnotetext{
${ }^{254}$ Binsley, Palestine Police Service, 106.

255 Palestine Gazette No. 584 CF $19^{\text {th }}$ April, 1936; The Palestine (Defence) Order in Council, 1931, Tegart Papers, (MECA GB 165-0281).

256 The five Arab leaders included President of the Arab party, Treasurer of the Arab Higher Committee, and President of the Arab Bank Jamal effendi el Husseini; Treasurer of the Arab Higher Committee and President of the Arab Bank, Ahmad Hilmi Pasha; Secretary Arab Higher Committee, Fuad effendi Saba; President of the Arab Youth Association, Yacub effendi Ghussein; and finally Mayor of Jerusalem, Dr. Hussein Khakhri effendi el Khalidi. These men were deported to the Seychelles Islands in what was seen as a largely ineffective action in response to a direct attack on the British government in Palestine. See Horne, A Job Well Done, 222.
} 
Committee, of which many of the deported Arab leaders were members, was disbanded and made illegal. The Mufti of Jerusalem was removed from his office in the Supreme Muslim Council and forced into hiding. Palestine frontier borders were closed and media censorship was imposed.

While in hiding the Mufti was able to designate subordinates to lead Arabs in a continued revolt against the British government, Jewish settlements, and the Zionist cause. Arab Overall Field Commander Fawzi ed Din Kauwakji was one such subordinate. ${ }^{257}$ As the most experienced military leader among the Arabs, Kauwakji was able to divide the region and help to establish gangs within each city, as well as in the countryside. Often these gangs were already in existence and Kauwakji served to bring them into the fold and disseminate the anti-British/anti-Zionist propaganda. These gangs, although poorly trained, were able to effectively throw the region into chaos, overthrow the local authorities in several cities and even establish a new government in a few of them.

As the violence of 1936 grew increasingly worse, yet another commission was called into existence. This time the commission was headed by Lord William Peel and news of its formation was published on July 7, $1937 .^{258}$ The Peel Commission was charged with determining the underlying causes of the disturbances which had been taking place over the course of the year and to "ascertain whether, upon a proper construction of the terms of the Mandate, either the Arabs or the Jews have any legitimate grievances on account of the way in which the Mandate

\footnotetext{
${ }^{257}$ Kauwakji was born in Syria, but rose to prominence in the Turkish Army during the First World War and was even decorated by the French Government with the Legion d'honeur for his efforts. He served as military advisor to King ibn Saud of Iraq for several years before traveling to Palestine in 1936 to aid the Mufti and his fellow Arabs in their fight against settlement and occupation.

${ }^{258}$ The members of the commission were Earl Peel, Sir Horae Rumbold, Sir Laure Hammond, Sir Morris Carter, Sir Harrold Morris, and Professor Reginald Coupland.
} 
has been or is being implemented." 259 If any of these "grievances" was well-founded, the commission was to make a recommendation as to what should be done about the situation.

The findings of the Peel Commission were not surprising to those who lived in Palestine. Peel concluded that Arab nationalism and Jewish nationalism had remained unchanged since the 1920s. If anything they had grown more intense. According to Peel, this nationalism was bred into each generation by the educational system and propagated by the youth movement. Further, Peel thought that the position of the Palestine Government, and by extension the British Government, was an unwinnable one. Any decision made would anger one party or the other. ${ }^{260}$ Recommendations for a restriction of Jewish immigration were again made, but what is significant about the Peel Commission is that it made the bold declaration that the British had fulfilled their obligation to establish a Jewish National Home as the Jewish population then exceeded four hundred thousand. ${ }^{261}$ Despite the recommendation to cap Jewish immigration at twelve thousand per year, the commission recognized that restrictions on Jewish immigration, "will not solve the Palestine problem. The National Home seems already too big to the Arabs and, whatever its size, it bars the way to their attainment of national independence." 262 With this understanding, the commission made its boldest assessment: Palestine should be partitioned. While it was stated that the commission was not in a position to lay out the terms for partition, it did recommend that the plan for partition which had been suggested nearly twenty years earlier was the only real solution available. ${ }^{263}$

\footnotetext{
259 The Peel Commission, found in Faraday Papers, GB165-0101 (MECA).

${ }^{260}$ The Peel Commission, Faraday Papers, GB165-0101 (MECA), 6

${ }^{261}$ The Peel Commission, Faraday Papers, GB165-0101 (MECA), 12-13

262 The Peel Commission, Faraday Papers, GB165-0101 (MECA), 13.

263 The Peel Commission, Faraday Papers, GB165-0101 (MECA), 20.; Also see, Roza I.M. El-Eini, Mandated Landscape: British Imperial Rule in Palestine, 1929-1948. (London: Routledge, 2006), 26-27.
} 
While all of these assessments were important to the problems that faced the Palestine Police, the section that affected them directly was concerned with the operation of the Mandate. According to the commission:

[a]lthough expenditure on public security rose from LP265,000 in 1923 to over LP862,000 in 1935-36 (and LP2,230,000 in 1936-37, the year of the disturbances), it is evident that the elementary duty of providing public security has not been discharged. Should disorder break out again of such a nature as to require the intervention of the Military, there should be no hesitation in enforcing martial law throughout the country under undivided military control. ${ }^{264}$

The Peel Commission clearly thought that the Palestine Police could not be trusted to handle a full insurrection alone. It made the recommendation that the police be reinforced with an increase in reserve units, as well as an increase in mounted units.

For all that he had done Spicer had reached the end of his career with the Palestine Police. It was time for a changing of the guard and the man to succeed him was the well-liked former Deputy Inspector-General, Alan Saunders. Saunders took over command in November 1937 just as violent attacks began to once again become more frequent. The kind of crime being committed stretched as far as one's imagination. A small sampling of Criminal Investigation Department entries between December 1937 and June 1938 reveal incidents such as gang kidnapping, Public Works Department stores set on fire, A Jewish bus fired upon, twenty-one telephone wires were cut, shots fired on police and shots returned, shots fired at a party of youths and girls, and a bomb fails to explode after being thrown into a bus stop. ${ }^{265}$ These kinds of headlines appeared every single day. There was not a single day without violence or an attempt at violence. Binsley recalls one of the Jewish buses that was fired upon:

\footnotetext{
264 The Peel Commission, Faraday Papers, GB165-0101 (MECA), 8-9.

${ }^{265}$ CID News Bulletins Dec 1937 - June 1938, Tegart Papers, (MECA GB165-0281).
} 
The Arab terrorists also made use of this waste ground to attack Jewish buses at night as they climbed slowly up the hill. One night, I was throwing bruised oranges from the side balcony on to this waste ground and Bobbie, a spaniel, naturally dashed on to retrieve them. He must have disturbed armed men, for shots were fired. At first I thought we would be attacked but duty bound went out armed only with a revolver to investigate. Going on the road I ran up the hill, the firing ceased and at the top I saw a deserted Jewish bus. Going inside and using my torch I saw a genteel old lady sitting quietly in her seat, seemingly not realizing her danger so putting my hand on her shoulder I asked her to leave the bus immediately. To my horror she was quite dead and fell on to the seat. The driver and passengers had ignored her in their panic to escape. I was sad and angry at both the terrorist and the driver who had deserted her, so was rather curt with him when he returned with assistance to collect the bus. ${ }^{266}$

These attacks and bouts of insurrection which began in the autumn of 1937 continued throughout all of 1938. The gangs were several different titles including rebels, bandits, and some went so far as to brand them terrorists. However the British soldiers and policemen in the region often took to calling them by the colloquial, 'Oozelbarts'. This name was derived from the title given to a leader of a gang, 'Qaid el Ursabi'. The plural form of this title is 'Ursabat' which was transformed into Oozelbart. The soldiers and policemen were under constant threat from Oozelbart attack. As Horne writes, “Throughout 1938 the stories of heroism, frustration and disasters still poured in, and the strain of it all began to show upon the faces of the men."267 Whether it was attacks made directly upon them or having to respond to attacks made on someone else at all hours of the day, the constant threat of terror took its toll upon the men.

In an attempt to combat this violence and in response to the Peel Commission, Sir Charles Tagert was asked to investigate the Palestine Police and offer recommendations for improvement. Tagert spent the next several years in and out of Palestine serving as an advisor calling for many worthwhile and constructive changes to the force. The most lasting of these

\footnotetext{
266 Binsley, Palestine Police Service, 113.

${ }^{267}$ Horne, A Job Well Done, 233.
} 
initiatives were the so called 'Tagert Forts'. These were a number of defensive barracks which were built throughout Palestine. Beginning in 1938 Tagert designed reinforced concrete fortresses that could survive an extended siege. ${ }^{268}$ In addition to the Tagert Forts, Tagert himself made the recommendation to expand the command structure of the force and add an additional 1,250 more men. This would allow the police to more effectively assume control of urban areas and expand into rural areas. ${ }^{269}$

However, as 1938 gave way to a new year the large-scale gang operations began to wane. With each passing month more and more local gang leaders were either being betrayed by their subordinates, turned in to the police, or caught. This lead to a crumbling of the leadership structure that Kauwajki had helped to establish. The end came quickly and by the summer of 1939 the Arab Rebellion was all but over. Yet it was a costly period in the history of the mandate. As Horne reported:

In the fifteen months beginning with $1^{\text {st }}$ January 1938, there had been over 6,000 major incidents logged by the police, 936 murders reported and 351 attempted murders. 2,125 incidents of sniping without including police and troop engagements. 472 bombs thrown and detonated. 364 cases of armed robbery. 1,453 cases of sabotage against government and commercial property. 323 persons abducted, mostly for purposes of ransom. 72 cases of intimidation for political ends. 236 Jews killed by Arabs, 435 Arabs killed by Jews, mostly while defending settlements. 1,200 rebels known to have been killed by police and military action and a further 535 rebels wounded. From the very beginning of the Arab Revolt to its termination, over 100 British Arab and Jewish police officers were killed, or died of wounds or accidents while on duty. The number of the servicemen killed during the same period is not known to the writer but would seem to be higher. ${ }^{270}$

\footnotetext{
${ }^{268}$ The buildings were set at a cost of LP. 2.5 million borne by Exchequer: "The 15 security buildings which the Palestine Government is constructing in various parts of the country, and the contracts for which have been awarded to a number of British, Jewish and Arab firms, will cost some two and a half million pounds, it is reliably learned. The cost of these structures, which will be in the nature of fortresses, will be borne by His Majesty's Government." See, The Palestine Post, May 2, 1940 in Tagert Papers. (MECA GB165-0281).

${ }^{269}$ Secret Document, Palestine Police Force: Re-Organization, Tagert Papers GB165-0281(MECA).

${ }^{270}$ Horne, A Job Well Done, 239.
} 
The Arab gangs had made their voice heard. They were willing to fight and die for the land that was theirs. However, many of the Jews in the region were also willing to fight for what they perceived as theirs. As Arab gangs made attacks on Jews and Jewish property, the Jewish communities felt the need to protect themselves. It was this need to protect and retaliate that led to the formation of a number of Jewish gangs. It was these new Jewish gangs that would pose the greatest threat to a Palestine Policeman's life from 1939 until the end of the mandate. Binsley captures the brief period of both Jewish and Arab terrorism:

In 1938-1939 the situation worsened, the Arab terrorists became more active in the towns, extorting money, attacking Jews and assassinating police informers, so although many murders were committed, no information was available. Often I have walked the main shopping street to investigate a reported shooting to find the body lying in the deserted street. It was so common, that shoppers and shopkeepers knew the routine... The Jews were the first to use time bombs to destroy their enemy, but as usual it was the innocent who were the victims. It occurred one morning in the main vegetable market in the central suq which was crowded daily by women shoppers buying the family fruit and vegetables. The time bomb had been delivered in a crate of Jewish oranges and exploded at peak time killing forty Arabs, mainly women and children. It was a gory sight, with severed limbs and bodies scattered among the debris of fruit and vegetables. This, of course, inflamed the Arabs and made our task more difficult. ${ }^{271}$

While for a time both parties were attacking each other and the police, as Great Britain moved into the Second World War, it was the Jewish terrorists who were the greatest threat to a constable's life. It is this subject which will be covered in the next chapter.

The1930s represent a time when the Palestine Police faced a number of new threats and challenges and responded to them remarkably well. As it has been shown, the 1929 Massacre

${ }^{271}$ Binsley, Palestine Police Service, 116. 
forced the Palestine Police to reevaluate how they policed the Mandate. This initiated a period of 'riot and reform'. The 1933 Riots vindicated the Police who proved that the three years of commissions, reports and reform allowed them to handle a sustained, near Mandate-wide disturbance without the assistance of the military. Further, the fact that their success in the 1933 Riots still initiated commissions and reform serves to underpin the idea that the force was a progressive one intent on looking toward the next threat. Finally, the Arab Revolt of 1933-1936 proved that the police had evolved to handle the threat of rioting and violence of Arab gangs, but could not anticipate the rise of a greater threat: terrorism. To conclude, in each case the force was tested to retain control and each case saw a certain measure of success. Regardless, following each incident there came a time of reform whereby the force attempted to adapt to the everchanging landscape of threats.

The 1930s were certainly the years of greatest growth for British colonial policing in the Palestine Mandate. While the late 1920s saw the beginning of training reforms, the continual state of 'riot and reform' forced the Palestine Police into a position where it had to become wellversed in traditional police work, riot control, and even combating early forms of sabotage and terrorist-like attacks. The brute force that was implemented in Ireland, and to some extent during the early days of the Mandate, simply could not work in the complex socio-political climate that existed in the 1930s. Yet, even though the Palestine Police reached a level of relative control, the following decade saw the explosion of a world war and with it a new, more overwhelming problem within the Mandate. 


\section{Chapter IV: War and the End of the Mandate}

The old idiom, 'out of the frying pan and into the fire' is used to describe jumping from a bad situation into an even worse one. This happens to be the case when considering the position of the Palestine Police during World War Two. As soon as the Arab Rebellion had reached its conclusion, Great Britain declared war on Germany. While not an immediate threat to Palestine in 1939 the war eventually began to loom large over the region. The police themselves were faced with a strange and dangerous situation; as the Arab Rebellion had grown more violent, armed Jewish gangs and defense organizations emerged. While not immediately a significant threat to the Palestine Police, groups such as the Stern Gang and the Irgun made wartime in Palestine a waking nightmare. Further, the Arab population, though loyal to the British, were always an enticing target for German propaganda. Also, in an unprecedented decision, after years of being treated as a military force, the Palestine Police were conscripted into military service. To sum up the wartime police perspective, the Palestine Police had to worry about attack and sabotage from Jewish terrorists, the defection and insurrection of the Arab population, all the while contributing to the war effort.

Following the war the situation did not improve. Jewish terrorists grew bolder and attacks on British personnel in the Mandate increased. The greatest recipient of violence was no longer the Jewish or Arab population, but the British. It quickly became clear that there was no saving the Mandate, at least not for the British themselves. Plans were drawn for the evacuation of Great Britain and by the summer of 1948 all of the Empire's agents had been recalled.

It is the argument of this chapter that the rise of Jewish paramilitary groups along with the events of the World War Two created a situation in Palestine in which the police could only combat, but not control. To support this argument we will attempt to first understand how the 
Palestine Police attempted to augment its training to both combat terrorism and be effective in a military capacity. Finally, the loss of control and the Empire's exit from the Mandate will be discussed and analyzed.

\section{War and Terrorism}

Before moving forward it is important to understand the Jewish military organizations that began during and in response to the Arab Rebellion. There were four main Jewish paramilitary forces of note during the Second World War. The first, The Hagana, was a large defensive organization, designed for the defense of Jewish towns, settlements and so on. By 1945 the Hagana was nearly one-hundred thousand strong. The second, the Palmach, was the offensive organization and strike force arm of the Hagana. The Palmach were well-trained, fulltime guerilla fighters. According to a secret report on Jewish military organizations, it was found that the ranks of the Palmach were largely filled with ex-European servicemen. For both of these units, it could be expected that they would follow the orders of the Jewish Agency. ${ }^{272}$ The government's report on the Jewish military organizations, which was filed at the end of the

Second World War, describes the two organizations as follows:

Trouble from the STERN GANG or IRGUN can be expected at any time, and had indeed been going on in a minor way throughout the last year. Conflict with the HAGANA or PALMACH is unlikely prior to an open break between the Government and the Jewish Agency, should the latter occur the PALMACH might be encountered anywhere, and its strength, and organization demand sound military precautions to avoid "unfortunate incidents". The main HAGANA is only likely to be met in a defencive role, but in such a role might put up a defence if a

\footnotetext{
272 "The term "Jewish Agency" first appeared in Article Four of the League of Nations Mandate for Palestine, which stipulated that "an appropriate Jewish agency shall be recognized as a public body for the purpose of advising and cooperating with the administration of Palestine in such economic, social, and other matters as may affect the establishment of the Jewish National Home and the interests of the Jewish population in Palestine." The article went on to recognize the Zionist Organization as such an agency "so long as its organization and constitution are in the opinion of the Mandatory appropriate." See, "Israel Society \& Culture: Jewish Agency for Israel (JAFI)" Accessed July 1, 2016. http://www.jewishvirtuallibrary.org/jsource/Orgs/jafi.html
} 
well populated area which could entail an attack of some considerable scope to overcome it. ${ }^{273}$

There were those groups which did not follow the orders of the Jewish Agency. It is important to make a distinction between these paramilitary forces and the terrorist organizations working in the Mandate such as the Irgun and Stern Gang. The Irgun was originally a sabotage organization that sought to destroy infrastructure in order to inhibit British operations. It often undertook operations such as blowing up pipelines, railways, and telegraph lines. Finally, there was the Stern Gang which specialized in assassination. Started by intellectual and Hebrew University of Jerusalem graduate, Abraham Stern, the gang has been described as "terrorists pure and simple," who "murder to shock the world - thinking only of the 'justice of their cause'irrespective of the innocence of their victims."274 The actions of the Irgun and Stern Gang can be compared to those taken by Sinn Fein and eventually the IRA. In each instance factions of larger groups grew tired of diplomatic attempts at a British exit. In Palestine, the situation was further complicated by Arab dissatisfaction with Jewish immigration. It was a surprising situation, to those in England, that during and after the resolution of World War II, "there should be two unofficial armies lined up against each other in a country that is still administered by His

\footnotetext{
${ }^{273}$ St. Anthony's College, Oxford, Middle East Center Archive, Philip Morris Papers, GB 165-0379, [Hereafter Morris Papers GB 165-0379 (MECA)], Jewish Military Organizations.; Binsley also describes these organizations years later with a greater emphasis on the betrayal he clearly felt by the actions of the Jewish terrorists: "There were three main groups, the Stern Gang, an extreme terrorists group which had operated for some years and whole leader Stern was shot by a police inspector, who was immediately transferred to another force for his own safety. The second and more numerous was the terrorist group Irgun which became active at the outbreak of war. One of their leaders, Menahem Begin, some years later was honoured by the 'Nobel Prize' for making a peace deal with Egypt and today (July 1982) as Prime Minister of Israel is using his armed forces to slaughter thousands of Palestinians and Lebanese civilians, including women and children in an invasion of Lebanon. The third and largest group was the more moderate Hagana, trained to defend the Jews of Palestine, recognized by the government but actively engaged in arranging illegal immigration. All three groups were supported by world Jewry. In my opinion Jewish citizens of all nations have a first loyalty to their race, loyalty to their country is of secondary importance." See, Binsley, Palestine Police Service, 129

${ }^{274}$ Memo, Morris Papers, GB 165-0379 (MECA), 5.
} 
Majesty's Government." ${ }^{275}$ Moreover, it was unsettling that two major groups had emerged with the prime directive to destroy the British Government in Palestine by any means necessary. More unsettling is the fact that these groups were operating within the Mandate prior to and during the war itself.

Jack Binsley recalls that in 1939 these terrorists started a campaign against the British which gradually increased and lasted until the end of the British mandate in 1948. It is clear from Binsley's writings that he and his fellow policemen, felt genuinely betrayed by the fact that they were being attacked and killed by the very people they had once protected. As Binsley wrote:

This, in my opinion, was the most blatant ingratitude toward a benevolent country who had granted them access to Palestine and then protected them from the Arabs to allow them [to] create a home in the Holy Land. Without British police protection, they would never have been allowed to live in a country owned by the Arabs for two thousand years. We acted as a buffer between them and the Arabs so that they could buy Arab land, dispossess the tenants and populate the most fertile land, pushing the Arabs back into the barren interior...Given an inch , they took a yard brought in more immigrants, until to pacify the Arabs, the Government ordained a quota of permitted immigrants based on the absorptive capacity of the country. They continued to exceed this by illegal immigration and continued to do so when the war started and all immigration ceased...The police, as usual, bore the brunt of their actions. We who had protected them at personal risk, trained them to use firearms to protect themselves, had this knowledge turned against us. Britain was fighting a war against their arch enemy, Hitler, yet they chose this time to wage their own private war against the British, preventing troops from being better employed fighting Germany. ${ }^{276}$

In this passage, Binsley is describing the actions of the Jewish terrorists during and after the

Second World War. It does not appear that Binsley harbored any malicious anti-Semitism. His previous writing has only good things to say about the Jews with whom he worked and policed.

${ }^{275}$ Memo, Morris Papers, GB165-0379 (MECA), 5.
${ }^{276}$ Binsley, Palestine Police Service, 128-129. 
It seems that this sense of betrayal was directed at violent nationalists who resorted to terrorism and targeted the British.

Moving back to the activity of the Arab militias, the leadership of these groups from city to city may have dissolved, but there were still many influential leaders in the overarching Arab community. ${ }^{277}$ Luckily for the British Empire, at the outbreak of war, the Arab community leaders were quick to swear allegiance to the Crown. This promised a more peaceful future for the Palestine Police than they had experienced in the previous three years, at least in terms of dealing with the Arabs. Still, it is easy to understand, especially in retrospect, that the antiSemitic propaganda of Hitler's Third Reich posed an attractive and potentially dangerous threat to an Arab population that was widely dissatisfied with continued Jewish immigration. So, while there was a period of notable peace during the war with respect to the Arabs, the Palestine Police needed to remain vigilant.

After the violence of the Arab Revolt subsided during the summer of 1939 it was only a matter of months until Great Britain declared war on Germany on September $3^{\text {rd }}$. The period of the Second World War represents a unique time in the history of the Palestine Police. For the first time violence from and between Arabs and Jews was not necessarily the greatest concern facing the security forces. Instead the Palestine Police, after years of being treated as a military force, was actually drafted by the empire into His Majesty's service. Further, many of the members of the force, who were ex-servicemen themselves, desired to rejoin their old regiments and aid in the war effort. While the British government, military forces, and security forces were largely concerned with threat of Axis powers working through neighboring countries, the specter

\footnotetext{
${ }^{277}$ Until this point the terms 'Jewish gangs' and 'Arab gangs' have been used. As Jewish gangs became more closely associated with more legitimate groups it is more accurate to describe them as militias.
} 
of Arab-Jewish unrest erupting always loomed large over the Palestine Mandate. This created a problem when a significant portion of the force wished to return to their former military regiments at the outbreak of war. With the possibility of Axis powers swaying the allegiance of the Arab population, the Palestine Police could not have their effectiveness crippled by force depletion. As former Constable William Hornsey put it:

[t]here must have been 1,000 ex-army men in the force at the time, all of us in the pink of fitness and we nearly all opted to go back to our regiments. Our regiments were our former homes and we had strong loyalties. There were so many requests to terminate contracts that Headquarters asked us to wait awhile, so that things could be sorted out. ${ }^{278}$

The British and Palestine Governments sought to end any attempt to leave the police by enacting the Defense Regulations of 1940. This had the effect of preventing any member of the security force from abandoning his post. The other outcome which will become important later was the option for the Palestine Police to be adopted as a military unit under the Army Act 1881. Initially, the Palestine government chose not to enact this provision. ${ }^{279}$

Because the men were not allowed to leave, anyone who refused to carry out their duties or tried to abandon the force was arrested and placed in prison. The problem with this system was that those who were arrested were only sentenced to three weeks in prison with allowances for special privileges. This amounted to men leaving the Palestine Police, being arrested, sent to prison, sun-bathing for three weeks, and then being dishonorably discharged to rejoin their old military regiment. Seeing that this three week 'mini-vacation' was not an effective deterrent the court changed the punishment. Instead of three weeks with privileges, the men were sentenced to three months with no privileges. This sentence was then to be carried out not at the local prison

\footnotetext{
${ }^{278}$ British Constable William Hornsey quoted in Horne, A Job Well Done, 244.

${ }^{279}$ Horne, A Job Well Done, 245.
} 
in Acre where the policemen were under the supervision of their former comrades, but at the Central Prison or at a local Farm Labor camp. This served as a suitable deterrent for most, but there were still those who were undaunted by the harsher sentence. The issue is further complicated by the idea that many of the men were uneducated on the legality of what was being done to them. Many felt that such action to keep them imprisoned for failure to fulfill their duties was illegal. Regardless, there were a couple of men who pressed their luck. When they tried to intentionally shirk their duties the courts sentenced them to eighteen months imprisonment. This measure effectively ended any further attempt to rejoin old military regiments. Further contributing to lost interest in trying to find their way to the war was the fact that the war was actually coming to them. ${ }^{280}$

Throughout 1941 and 1942 the Germans were battling their way through Africa and had taken control of a large portion of Egypt. Syria was under the control of the Vichy government and a swift incursion into Turkey by the Axis powers seemed possible. By June 1942 the situation seemed dire enough to enact the provision of the Defense Regulations of 1940 previously mentioned which allowed the government to transform a police force into a military force. So, on 27 May 1942, the Palestine High Commissioner, Sir Harold Alfred MacMichael, made a proclamation which was published on 4 June 1942. The proclamation claimed that the Palestine Police were a military force for the remainder of the war, and were charged with the defense of Palestine. This is unique not only to the history of the Palestine Police, but to colonial policing in general. To this point there had been no other police force within the empire that had been called upon for military service.

\footnotetext{
${ }^{280}$ Jewish Military Organizations, Morris GB165 - 0379 (MECA).
} 
Horne mentions that during this time many men expressed their dissatisfaction with being a part of His Majesty's Armed Forces of the Crown. While many of them were clamoring to rejoin their old regiments only two years earlier, now presented with the chance to serve in the war under the Palestine Police some thought that the action was illegal. However, petitions questioning the legality of the Army Act were shot down by the Palestine Supreme Court citing it as a form of conscription. While this was essentially true, there was a problem with such a decision. A portion of the Palestine Police was still comprised of men from the Republic of Ireland. Although working for the British Empire which was at war, the Republic had not declared war on the Axis powers. The Irishmen were conscripted like everyone else and luckily made no objection. ${ }^{281}$

One of the areas where the Palestine Police was most effective was the transportation of troops and supplies north to aid in the efforts against Vichy-controlled Syria. Before the police were conscripted as a military force, they were still helping to contribute to the war effort. As more troops began to enter the region to combat the threat from Syria they faced a long and dangerous road north. The Palestine Police who were experts in carrying out dangerous escort missions in the rural areas of Palestine from their time during the Arab Rebellion, seemed like the best choice to help the army. They faced a number of roadblocks and ambushes while making sure whatever they were carrying made it to the destination. They continued to do so until 12 July 1941 when Vichy commander General Henri Dentz called for an armistice and ended the military actions in Syria. ${ }^{282}$

\footnotetext{
${ }^{281}$ Horne, A Job Well Done, 248-251.

${ }^{282}$ Horne, A Job Well Done, 258.
} 
The training of the Palestine Police seemed to change with their new war-time duties. When looking at the service records of Stephen Edwards, we see that throughout the 1940s there was a serious emphasis on military readiness. The training program of the Palestine Police throughout the 1930s shows a number of 'continuing education' style courses to help the men adapt to new and emerging threats. For instance Edward's record shows courses taken on Arabic language proficiency and border control during the Arab Rebellion. However, in the 1940s there is a marked shift into military training. One such course that Edwards took was on 'Platoon Weapons'. It appear that this course required a proficiency in the application, technical knowledge, general knowledge, general military knowledge, and tactical ability in the use of military weaponry. ${ }^{283}$

Wartime also saw the return of the former Commandant of the Palestine Police, Mavrogordato. Now serving as Brigadier General for the $9^{\text {th }}$ Army, 'Mavro' was responsible for security within Lebanon and Syria. When choosing who would serve under him he could think of none more qualified than men from the Palestine Police. His former men knew the territory, they spoke the language, and were well suited to gather together information and discern what was important. Sergeant Arthur Callan who had come to the region with the $9^{\text {th }}$ Army and Mavrogordato explained in a letter to Edward Horne how the members of the intelligence branches learned a great deal from the Palestine Police. He went on to write:

I honestly believe that everything I know in life of any value to me has come from the Palestine Police and the security and military intelligence system we set up in Lebanon and Syria was a wonderful example or just how things ought to be done. Palestine Police fashion. In this we gave a service out of all proportion to our numbers. $^{284}$

\footnotetext{
${ }^{283}$ Service Register: Stephen Edwards, Edwards Papers, GB165-0345(MECA).

${ }^{284}$ Letter from British Sergeant Arthur (killer) Callan to Edward Horne, see Horne, A Job Well Done, $260-261$.
} 
The involvement of the Palestine Police in an Army intelligence endeavor under the command of a former Inspector General of the force is yet another example of how influential the force had become within the empire during the war.

When V.E. Day arrived celebrations erupted across Palestine. This moment marks not only the victory of the Allies over the European Axis powers, but also the zenith of the Palestine Police power and ability. The war had necessitated the recruitment and training of a record number of constables. This brought the force's numbers as high as they would ever be. Some of the skills that the force was already known for, such as convoy-personnel protection, investigation, and intelligence gathering were honed to an even greater extent. Finally, after decades of trial, error, commission, report, and reform, the force was as close to understanding how to effectively police and control the region as they would ever be. However, this moment would not last. After the conclusion of the war, men left the force at an alarming rate. Jewish terrorist organizations grew ever more violent, and the Mandate's days were numbered, even if the Palestine Police didn't know it.

\section{The End of Empire in Palestine}

The Palestine Police came out of the Second World War facing very different problems than it had in 1939. The threat of Arab insurrection was no longer the greatest threat to a policeman's life. Instead the Jewish terrorists served as the greatest menace to the Palestine Police. The way the force dealt with this threat had to be reconfigured as it entered the final chapter of its existence.

Inspector General Captain J.M. Rymer Jones had brought the Palestine Police through the Second World War and aided it in dealing with the challenges of war, as well as a new enemy in 
Jewish terrorists. ${ }^{285}$ However, Rymer's time with the force had always had an expiration date upon it. He was on loan to the Palestine Police from the British Metropolitan Police. His twoyear contract had been extended for another year at his request. However, by March of 1946 his time had run out and his superiors request that he return to London. There was great deal of debate about who would replace the innovative and well-loved Inspector General. It was not unreasonable to assume that one of the Assistant Inspector Generals would be promoted. In the end Lt. Col. W.N. Gray of the Royal Marines was chosen to lead the force. This was a perplexing choice as Gray had no previous experience or connection to any police force. As it has been shown the Palestine Police and its forerunners have always been heavily populated and led by military men. However, these men, at least those chosen to lead, had some previous affiliation or experience in policing. ${ }^{286}$

As if Gray did not face enough of an uphill battle, the post-war circumstances in Palestine had placed him in a difficult position. The two most effective units used against Jewish terrorists up to that point had been the Police Mobile Force and the Criminal Investigation Department, or CID. ${ }^{287}$ By the time Gray had taken command he was put in a position where he had to dismantle the Police Mobile Force and redistribute its men. The reasoning behind the dismantling of PMF according to the Palestine Post is as follows:

The P.M.F was formed during the war, Col. Gray's Order states, when the Army was fully occupied and unable to assist the Police when military help was unfortunately necessary. That situation no longer exists, and the necessity of the P.M.F has lapsed. ${ }^{288}$

\footnotetext{
${ }^{285}$ Rymer took over command from Alan Saunders in September 1943.

${ }^{286}$ Horne, A Job Well Done, 555-557.

${ }^{287}$ CID had been in operation as a department of the Palestine Police since 1920. It served as an integral part of the day to day policing of Palestine and later was instrumental in combating Jewish and Arab gangs. See, Horne, A Job Well Done, 463-478.

288 St. Anthony's College, Oxford, Middle East Center Archive, Tony Kirby Papers, GB 165-0585, [Hereafter Kirby Papers GB 165-0585 (MECA)], Palestine Post.
} 
The reason for this stemmed from leave policy during the war. As war began all those from the UK were not permitted leave to return home. With the exception of a few men permitted to leave in 1944, most of the British contingent had not seen their family in seven years. When leave was finally permitted in 1945 a significant portion of the force was sent home on leave. ${ }^{289}$ The men were deservedly upset about not seeing their loved ones for the duration of the war. As one officer put it,

[s]ome of us have anything from 9 to 20 years' service in the Force and were due for leave when war broke out; others have been out here six to eight years without UK leave and have been on the waiting list since January. We were on the list for the May boat but are still waiting to get our wives and children home for a little bit of English summer that might remain by the time we get there. ${ }^{290}$

This would not have created such a serious problem for Gray except for the fact that once home, many of the men did not wish to return to Palestine. Already combatting a shortage of men, Gray was forced to disband the Police Mobile Force and reallocate the men and equipment. As Horne described the situation, "the terrorists could count upon poorer searching, poorer screening of suspects, poorer powers of perceptions by the security forces." 291

The relationship between the military units stationed in Palestine and the Palestine Police had also changed. As it has already been shown the use of military units became progressively more efficient since the 1929 Massacres. In the 1933 Revolt after the Dowbiggin Report, military units were always on the standby should the Palestine Police find themselves in a position that they

\footnotetext{
${ }^{289}$ While with the PMF, Stephen Edwards took three tours of leave in 1945. The first taking place was personal in nature from May $10^{\text {th }}, 1945$ to June $17^{\text {th }} 1945$, and again from October $12^{\text {th }}, 1945$ to November $16^{\text {th }}, 1945$. However, in between it would appear that he was on official duty in the UK as a recruiting officer. When he returned to Palestine he brought his new wife with him.

${ }^{290}$ Kirby Papers, GB165-0585 (MECA). The Palestine Post, 12 August 1945 'Leave for British Police' from "Homesick"

${ }^{291}$ Horne, A Job Well Done, 559.
} 
could not handle. Even during the Arab Revolt of 1936-1939 military units had a policeman embedded with them to act as a liaison and a guide. Raymond Cafferata provides a good example of this relationship. After his long career in Palestine he had grown close to many of the military personnel in the region. Upon his departure from the Holy Land, Major General L.G. Whistler wrote to Cafferata:

At this time, when your work in Palestine is completed and the stay of 3rd British Infantry Division in North Palestine is nearing its end, I should like to take the opportunity of thank you for the very able and loyal support you and your police forces have given me and my soldiers in the carrying out of our many combined tasks." 292

Despite the close relationship that had been forged over the previous fifteen years, by 1946 this relationship had been discontinued after the war. There was a kind of 'changing of the guard' from the wartime military occupants. As Horne describes the situation from his time, "soldiers fresh from the Italian or European fronts—seasoned airborne soldiers and desert rats—all thought they knew best and that Jewish terrorists were just another enemy. Very few soldiers ever showed interest in advice from the police nor was such advice encouraged." 293 The military's inability to fully grasp the nuance and deep history that rooted the Jewish terrorist groups was to everyone's detriment as the Mandate only became a more dangerous place to inhabit.

The already complex nature of Jewish nationalism became even more complicated as disparate groups began to work together. The Palestine Post reported the situation in July 1946 and claimed that the Haganah and its associated force of Palmach were working under the political control of prominent members of the Jewish Agency. They went on to claim that the

\footnotetext{
${ }^{292}$ Letter from Maj. Gen. I.G. Whistler to Cafferata $19^{\text {th }}$ March 1946, Cafferata Papers GB165-0044 (MECA).

${ }^{293}$ Horne, 560.
} 
two had been engaging in carefully planned movements of sabotage and violence under the name of the "Jewish Resistance Movement." Traditionally, these two forces were more legitimate military forces working toward the protection of the Jewish population. They were not an organization known for sabotage or assassination. It was the Irgun and Stern Gang who were normally associated with terrorist and sabotage activity. The Post went on to claim that the Irgun and the Stern Gang had worked since the last autumn in cooperation with Haganah's high command on certain of these operations. Further, the broadcasting station, Kol Israel, which claimed to be the 'voice of the resistance movement,' was working under the general direction of the Jewish Agency, and had been supporting these organization. ${ }^{294}$ In response, the Jewish Agency denied these charges in a July 26, 1946 report to the Palestine Post. ${ }^{295}$

As far as the competing identities within both the Jewish and Arab communities, former Constable, Roy Leadbeater thought that no matter what was being done by the Irgun or the Hagana, there were still those within the community who did not necessarily agree. In an oral interview he recounted the story of a crowd overrunning a Palestine Police officer: "This was a Jewish mob. And a Jew ran out and stood over the Englishman and said, 'Anybody tries to injure this man, I'll kill him.' And saved his life. Because not all Jews agreed with the Irgun or the Haganah..."296 However, Leadbeater claimed that he understood the motivations of the Irgun and to a certain extent had sympathy for what they were going through. As Leadbeater recounted:

We had sympathy for the Jews, at least I did. And I'm sure of my fellows did and certainly some of the army that had actually, I think it was the British Seventh Armored that was first into one of the concentration camps. And then they were

\footnotetext{
294 The Palestine Post, July 25, 1946.

295 The Palestine Post, July 26, 1946.

296 St. Anthony’s College, Oxford, Middle East Center Archive, Roy Leadbeater Papers, GB 165-0412, [Hereafter Papers GB 165-0421 (MECA)], Oral history of Roy Leadbeater by Eugene Rogan, 18
} 
posted to Palestine and they had to ship... when these illegal immigrants, Jews, came in Britain was trying to keep the quota down because Arabs were getting upset. And they put them on ships and took them to Cyprus."297

Despite this understanding and measured sympathy, Leadbeater reminds us that in the end most the police really did hate the Irgun and the Stern Gang, but certainly didn't want to hurt all Jews. Speaking of facing Jewish 'mobs' Leadbeater said: "You were there facing people that you don't want to hurt because you know they've been hurt so many times before." 298 This is certainly something to consider in the post-World War Two era. The handling of the problem of Jewish terrorism was incredibly delicate when considering the events of the Holocaust. ${ }^{299}$

The papers of Constable John Poole allow us to see the kind of crime that was occurring during the period. Having served from 1943 until the end of the mandate in 1948 Pool retained a number of daily crime reports. These reports show everything from petty crimes to major terrorist attacks. What is most striking about these reports was the consistent nature of attacks against British personnel. Most of the time these attacks were small, usually carried out by a handful of men, but always with deadly purpose in mind. The attacks most often attempted were long range sniping and bombings. These are, in some ways, the most troubling methods of terrorism; they are unseen and nearly impossible to anticipate or prevent. ${ }^{300}$ Raymond Cafferata

\footnotetext{
297 Oral history of Roy Leadbeater by Eugene Rogan Roy Leadbeater GB165 - 0412 (MECA). 20

298 Oral history of Roy Leadbeater by Eugene Rogan Roy Leadbeater GB165 - 0412 (MECA).21

${ }^{299}$ In his interview he attributed his perhaps heightened sense of sympathy to his upbringing as an orphan by saying, "One thing I used to think, England with its colonies, if we got used to different nationalities more so, so I had this sympathy. Not only that I've been an orphan myself, where every day mattered in the way I lived because I always say, some people say to me, "You haven't changed much since we saw you last." Well, I was old when I was a teenager. I haven't gotten older; I've got younger as I've got older now. So that's what gave me sympathy." See Oral history of Roy Leadbeater by Eugene Rogan in Leadbeater Papers GB165

${ }^{300}$ St. Anthony's College, Oxford, Middle East Center Archive, John Poole Papers, GB 165-0379, [Hereafter Poole Papers GB 165-0379 (MECA)].
} 
illustrates this point in a letter written to Chief Secretary J.V.W. Shaw. Following the failed attempt to chase down a group of terrorists in Haifa on $20^{\text {th }}$ January 1946 Cafferata explained:

I am very much afraid that our chances of getting any of those responsible finished on the spot. In these sort of shows unless one has the luck to kill the attackers, then the chances are 100 to 1 against ever getting hold of them. It was a very carefully planned show and having avoided the main ambush a military truck was standing concealed in a turning further down the road to finish the job. Had it not been for this truck we should have been able to get at them and really smarten them up. ${ }^{301}$

The Palestine Police had been combating these kinds of terrorist activity for years, the difference was that now the frequency of attacks and sabotage was beginning to climb at a rapid pace. As has been the case so many times before, the perceived solution was to call in experts and attempt to implement reform.

The man charged with this task was Lt. Col. Sir Charles Wickham who was brought in to assess the situation in Palestine. ${ }^{302}$ Wickham was able to produce his report in a quick four months, starting on August $1^{\text {st }} 1946$ and ending on December $2^{\text {nd }}$. Horne concludes that the results of the report while not 'unhealthy, or undesirable' but were "at variance with police experience in Palestine." ${ }^{303}$ One aspect that Wickham's report pointed to was the 'militarisation of the police'. This is an aspect that has been brought up many times throughout this study and Wickham's conclusion is consistent with the opinion of many policemen going back to Douglas

\footnotetext{
${ }^{301}$ Letter from Cafferata to Chief Secretary J.V.W. Shaw 19 February, 1946. Cafferata Papers GB165-0044 (MECA).

302 Wickham was one of the Empire's most experienced policemen. His resume was extensive starting in 1899 when he was commissioned into the Norfolk Regiment fighting in the South Africa War and World War One. He then served as part of the military mission to Vladivostok prior to being named Divisional Commissioner of the RIC. After the resolution of the Anglo-Irish War he moved north to serve as Inspector General of Royal Ulster Constabulary in Northern Ireland until 1945. See Horne, A Job Well Done, 569-570.

${ }^{303}$ Horne, A Job Well Done, 562.
} 
Duff in 1922. Although he was the Inspector General of a militarized police force for forty-seven years Wickham wrote,

Police are civilians and are extremely jealous of their civilian status. They resent a military atmosphere, military discipline or being turned into military units where their efficiency inevitably must be judged as soldiers and not as police. They joined to do police duty and not to be soldiers. ${ }^{304}$

Horne goes on to tell us that Wickham and his assistant Moffat also found misplaced fault with the CID in failing to gain intelligence from the Jewish community. Horne argues that the report fails to recognize the difficulty in gathering useful intelligence from a hostile and uncooperative community that had been alienated by the British Government. He largely dismisses the report and claims that it was 'quietly forgotten.'305

Despite the seemingly worthless assessment given by Wickham, the training of men during this period seems to have adequately prepared them for what they would face in the line of duty. Roy Leadbeater, who joined the force in 1946, described the training process as being very focused on the prevention and detection of crime. The training consisted of 12 weeks of drill, weapons training, and instruction on law and order. Leadbeater described the latter aspect as "just as though we were in England." 306 This included instruction on how to present oneself in court, how to properly assess and take notes on a crime. Another aspect that endured was a heavy emphasis on learning Arabic and/or Hebrew. One part of Leadbeater's training that has not appeared in previous iterations is the instruction on the 'extreme groups' on the Arab side and the Irgun, Hagana and the Stern Gang on the Jewish side. ${ }^{307}$ He goes further to reveal that the

\footnotetext{
${ }^{304}$ Quoted from the Wickham report, see Horne, A Job Well Done, 562.

${ }^{305}$ Horne, A Job Well Done, 563.

306 Oral history of Roy Leadbeater by Eugene Rogan Roy, Leadbeater Papers GB165 - 0412 MECA 5

${ }^{307}$ Oral history of Roy Leadbeater by Eugene Rogan Roy, Leadbeater Papers GB165 - 0412 (MECA), 5
} 
training process helped to discern and discourage political leaning, noting that, "If they thought you had been pro-Arab or pro-Jewish, and especially if you were involved with a girlfriend, then you could be sent home." 308 Once training was complete it is clear that there were still protocols that had endured for years. One of these was the way that the Palestine Police handled mobs of potentially dangerous people. According to Leadbeater

The drill was, the officer would stand up and he would say in Hebrew, Arabic, and English: "I order you to disperse immediately and quietly. If you don't, we open fire upon you." But we were instructed when we heard that you never fire until you'd heard the end of the word "fire." Because the officer would then say, "At the knees of the crowd." But we never got to that state and I was never in that situation, but I knew the drill. ${ }^{309}$

Although Leadbeater himself was never forced to fire into a crowd he did recall that these incidents were not without danger. While the police were in their firing line and the crowd was dispersing, there would often be those up on rooftops 'loosening rocks off the building' to drop on them. Another tactic that was employed was putting women and children at the front of the crowd to prevent the police from firing into it. Luckily for Leadbeater the incidents in which he was involved never came to shots being fired. ${ }^{310}$

Looking to improve the situation without using the Wickham report, Gray sought to reinvent a practice from the Arab Rebellion. During the Rebellion, 'seek and search' missions were used to gather information and undermine Arab plots. Gray thought that similar tactics could be used to thwart Jewish terrorists. Under Brigadier E.B. Fergusson, who was named Assistant Inspector General of Police in early 1947, a plan was formulated to increase the effectiveness of such missions. Upon Fergusson's request the British Government sent a number of ex-commando and

\footnotetext{
${ }^{308}$ Oral history of Roy Leadbeater by Eugene Rogan Roy, Leadbeater Papers GB165 - 0412 (MECA)

${ }^{309}$ Oral history of Roy Leadbeater by Eugene Rogan Roy, Leadbeater Papers GB165 - 0412 (MECA), 18

${ }^{310}$ Oral history of Roy Leadbeater by Eugene Rogan Roy Leadbeater GB165 - 0412 (MECA), 18
} 
Special Air Service men to join the Palestine Police. ${ }^{311}$ These men were quickly given command of squads where they were to disappear into the Jewish communities posing as local Jews in order to flush out terrorists. This practice of using police as special forces operators is fraught with risk. Special Forces generally work under more legally 'gray' conditions whereas these Palestine Police units had to continue to adhere to the law. This sentiment was illustrated by the 'Rubowitz Affair'. To explain, Alexander Rubowitz was a suspected terrorist in one of these Jewish communities. After his disappearance, Roy Farran, a member of one of the specialized units, was accused of his murder. He was brought before a Military Court and acquitted to the dissatisfaction of the Jewish community.

According to Farran he went to Palestine at the behest of the Military Secretary and thought "there was a good chance that [he] might be able to do something to smash those "thugs" who murdered innocent people for doubtful political ends." ${ }^{312}$ Upon arrival he was briefed and given the parameters of his duty:

We were to advise on defence against terror and to take an active part in hunting the dissidents. We would each select ten volunteers from our districts - mine were to be Tel Aviv and Jerusalem — and train them for a fortnight in our methods. It was to all intents and purposes a carte blanche and the original conception of our part filled me with excitement. A free hand for us against terror when all other were so closely hobbled!"’313

\footnotetext{
${ }^{311}$ The Special Air Service or SAS is a special forces unit of the British Army and was formed in 1941. The unit specializes in intelligence gathering, hostage rescue, counter terrorism, and covert reconnaissance. Earning its stripes during the desert campaign against the Axis powers, the SAS garnered a special reputation for attacking military targets, including airfields, behind enemy lines. See Malcolm James, Born of the Desert: With the SAS in North Africa. (Greenhill Books, London: 1945).Also, Roy Farran, Winged Dagger: Adventures Special Service, (London: Collins, 1948).

${ }^{312}$ Farran, Winged Dagger, 347. Farran didn't have a high opinion of the methods employed by the Palestine Police: "Police methods were so amateurish that even to a non-policeman they were wince-making. Acting on about as much information as would fill a small thimble, they would occasionally make a half-hearted search. During the whole of my stay in Palestine I did not hear of a single case being solved by deduction from clues found on the scene of a crime. What is more, there was rarely an instance of one arrest providing a thread which would lead to the discovery of something bigger. In fact, there were no threads to follow-just windfalls." See Farran, Winged Dagger, 351.

${ }^{313}$ Farran, Winged Dagger, 348.
} 
Farran claims that his group was making real progress until the 'Rubovitz Case'.

According to Farran, the Palestine Post began to publish frequent articles relating to an abducted youth and a hat that had been found at the scene of the abduction, which had a name that appeared to be similar to Farran's. He writes, "It did not matter that I could prove that at that moment I was disguised as an Arab, having dinner with Arabs in another part of Jerusalem called Givat Shaul. There was no evidence, but the ugly finger of suspicion was pointed at me. ${ }^{314}$ Still, due to the appearance of impropriety and potential for disaster, these squads were immediately disbanded. ${ }^{315}$ However, this again demonstrates how attempting to use military units, especially those who have not undergone sufficient training, as police was a dangerous practice.

For as much trouble as these squads caused they did little to curb the danger posed by Jewish terrorists. If anything attacks only increased throughout 1947. The police and government officials were under attack nearly every day. So great was the danger that even the families of policemen and government officials were no longer safe. ${ }^{316}$ With this in mind on January $31^{\text {st }}$ 1947, 'Operation Polly' was carried out. This was an operation to evacuate all non-combatant civilian residents in Palestine. The Palestine Post reported on the first of the evacuees on February 3, 1947: “The first British evacuees left Palestine by air yesterday. They were 43 wives and children of British officials of the Consolidated Refineries of Haifa, and the wife of a

\footnotetext{
${ }^{314}$ Farran, Winged Dagger, 351.

${ }^{315}$ Horne, A Job Well Done, 570.

${ }^{316}$ In January 1947 Stephen Edwards daughter, Dorothy Frances was born in Jerusalem. In Edward's papers are correspondence between he and the Medical authorities. Edwards wanted Isabel, his wife, to be confined in Tel Aviv, and not in Jerusalem, due to the dangerous conditions on the road. However the authorities were not prepared for her to go to the Hospital in Tel Aviv saying that it was policy to use Government hospitals, so she had to travel in an armored convoy to Jerusalem, with soldiers eagerly pointing out the burnt out wrecks of previous ambushes. In February 1947 she and Frances (barely one month old) were evacuated to the Sinai under Operation Polly. See Edwards Papers GB165-0354 (MECA).
} 
member of the Haifa staff of the Shell Company." ${ }^{317}$ Over five hundred women and children were first moved to barracks and then transported to Egypt on February $5^{\text {th }}$. Following Operation Polly was 'Operation Cantonment' which moved all British personnel into 'safe areas'. The Palestine Police began to take on more escort duty and their patrols were always done in armored car. ${ }^{318}$ These actions served to completely reverse the improvements in police practice that had been made in the previous two decades. The Palestine Police were becoming less of a police force. They and the government were losing control over the region, and everyone knew it.

On February $18^{\text {th }} 1947$ the British Government made the decision that the problem of the Mandate would be turned over to the United Nations. With this announcement the United Nations Special Commission on Palestine was assembled to assess the situation in the Mandate. The conference took place on Tuesday 24 June 1947, eight days after the arrival of the Committee in Palestine. The UNO Committee was represented by the Chairman, Mr. E.Sandstorm, Dr. Victor Hoo, and Dr. Ralph Bunche. The first order of business was to try and understand the motivation of the Irgun. The Commander of the Irgun clearly laid out five points of contention held against the British,

1. Israel is the homeland of the Jews

2. They want both E. and W. of the Jordan.

3. Immediate repatriation of all Jews wishing to be repatriated to Palestine

4. They reject the Labour Party's assertion that Arabs would be expelled. There is enough room in Palestine for all

5. They must meet Britain's force with force. ${ }^{319}$

\footnotetext{
${ }^{317}$ The Palestine Post, Monday, February 3, 1947.

${ }^{318}$ See Edwards Papers GB165-0354 (MECA).; Also Horne, A Job Well Done, 568.

${ }^{319}$ St. Anthony's College, Oxford, Middle East Center Archive, United Nations Special Committee on Palestine, GB 165-0290, [Hereafter UNSCOP, GB 165-0290 (MECA)], 8.
} 
The Irgun seemed to think that it was the British were the real instigator of discontent between the Arabs and Jews. According to the Commander, if the British were to leave then there would be peace and if the Jews were to be attacked then they were, in his opinion capable of protecting themselves. He was asked what might happen to Arab land holdings in a Jewish state of Palestine. He replied that land now held by Arabs would be retained by them, but that in the New Palestine there would be need for agrarian reform. As in ancient times latifundia existed in Palestine. There are vast lands held by Arab feudal landlords which are never worked, and large tracts held by the British. The government of the new Palestine would have to adjust this situation. Every Arab and every Jewish farmer would have to be assured of enough land for a prosperous self-supporting farm. ${ }^{320}$ Yet, the most succinct estimation made by the Commander was as follows, "We are convinced that we must fight or the Jewish people will be destroyed." 321

It was on December $11^{\text {th }}$ of that year that the Palestine Police received word that they would be evacuated by May $15^{\text {th }} 1948$. This announcement meant a great deal of uncertainty for the members of the security force. Within a matter of months they would be without a job. Yet before they could worry about future employment, they had to ensure that they made it out of Palestine alive, something that was anything but certain. Arabs began to pour over the border from Syria in the hopes of pushing the Jews out of the territory. For a time the Trans-Jordan Frontier Force was able to halt an Arab advance, but by early January 1948 the force had been disbanded and thus the Jewish Haganna knew that they had to mobilize forces to fight against the Arabs. The security and military forces within Palestine were put in an impossible position at this point. In much the same way that Lord Mountbatten had decided to pragmatically draw dividing

\footnotetext{
${ }^{320}$ UNSCOP, GB 165-0290 (MECA), 10.

${ }^{321}$ UNSCOP, GB 165-0290 (MECA), 11.
} 
lines in India and leave, British forces in Palestine were inclined to allow the Jews and Arabs to fight one another lest they be pulled into a quagmire of a conflict.

To avoid even the appearance of partiality as the withdrawal began, policemen were ordered to burn sensitive files so either side could not access the valuable intelligence on one another. They were ordered to drive all the armored cars over a cliff and set them ablaze. The plan called for the force to evacuate north toward Haifa. By this point violence between Arab irregulars and Jews was fairly widespread. Still, the British forces tried to stay out of it:

On the whole the British remained aloof, it being the government aim to keep the roads open for evacuation purposes. The army Brigadiers had written orders not to interfere unless the roadways were actually threatened. The moment such a threat existed the security forces turned out to extricate Jews mostly from and Arab ambush, although sometimes it was the other way round... Britain saw no reason to interfere in a war between the Children of Israel and Ishmael. ${ }^{322}$

As each police station along the evacuation route was abandoned, Arabs and Jews fought for control over it. The last of these was the depot area of Mount Scopus where it all began and so many policemen had been trained. Just before departure, Assistant Superintendent Buck Reeves saw a brass memorial plaque of Lt. Col. Bramley, the founder and first commander of the force, screwed to a wall. Unwilling to let such an item be left to disgrace he took precious moments to unscrew the plaque and years later gifted it to Bramley's daughter. Few left Palestine with a smile upon their face. It had been their home. For some, Palestine was more home than anywhere else. Horne himself mused about the moment:

Yet the Jewish Rebellion, for that is what it all came to in the end, had a curious twist, because it was lost by the British, simply because they did not possess the will to win. In a sense everyone lost. The Arabs, because with the British withdrawal they lost their country. Land, houses and way of life, all of which was simply taken away. The British because they were

\footnotetext{
${ }^{322}$ Horne, 578.
} 
out generalled by the ruthlessness of the terrorists, who were in the end actively supported and even applauded by lost Jews in Palestine and elsewhere. Finally although Israel was born, a long cherished dream of the Jewish world, Jews lost too; because their new state arrived in a sea of violence amid considerable moral doubt as to her respectability. ${ }^{323}$

Although this was the end of Britain in Palestine, it certainly was not the end of policing the Empire. The British Empire was in need of skilled policemen, especially in Africa. Nearly 1,300 of the Palestine Police continued their colonial policing careers elsewhere in the empire. ${ }^{324}$ According to Binsley, those with over ten years' service were entitled to a pension provided they were of adequate rank. Binsley himself, "was offered a choice of awaiting a further appointment, taking a full pension or taking a three quarter pension with the remaining quarter calculated for a period of ten years to be paid as a lump sum." ${ }^{325}$ Not being able to anticipate the pressing need for police that followed quickly in Kenya and Malaya he opted for the full pension. The greatest number, some four-hundred-fifty of these men, traveled to Malaya to help quell the Malayan rebellion. Another rebellion, the Mau Mau rebellion in Kenya, created work for nearly 200 exPalestine Policemen. Other countries that saw the adoption of former members were Hong Kong, Tripolitania, Cyrenaica, Eritrea, Cyprus, the Canal Zone in Egypt, the Aden Protectorate, and a number of assorted countries throughout Africa. However, the largest employer of former Palestine Policemen was the Iraq Petroleum Company who were happy to hire security professionals who spoke the language and were familiar with the Middle East. ${ }^{326}$

\footnotetext{
${ }^{323}$ Horne, A Job Well Done, 273.

${ }^{324}$ Horne, A Job Well Done, 273.

${ }^{325}$ Binsley, Palestine Police Service, 221.

${ }^{326}$ Horne, A Job Well Done, 573.
} 
Despite the various directions that men took after the Palestine Police, many were left with a sense that the world had forgotten their efforts, or worse yet, never even knew about them in the first place. As Leadbeater recounts,

I bought a first class ticket and I sat in the carriage in my uniform and this businessman looked at me...He said, "That's an odd uniform you're wearing." I said, "Yes, it's the Palestine Police." He said, "Never heard of them." I thought, gee...riding in the first class carriage with whom I assume is an intelligent businessman and he doesn't know where Palestine is. ${ }^{327}$

Regardless of how they began their careers or where they went after, Palestine was no longer theirs to police.

With the declaration of war on Germany, the Palestine Police faced an entirely new set of problems than any they had faced previously. Jewish paramilitary units and defense organizations grew more violent and forced the police to try and adapt. Groups such as the Stern Gang and the Irgun quickly became the greatest threat to British personnel in the Mandate. Further, the Arab population, though loyal to the British, were always an enticing target for German propaganda. In addition to all of this the police had to deal with the unprecedented event of being conscripted into military service.

Following the war the situation grew even more untenable. Jewish terrorists grew bolder and attacks on British personnel in the Mandate increased. The greatest target of violence was no longer the Jewish or Arab population, but the British. It quickly became clear that there was no saving the Mandate, at least not for the British. Plans were drawn for the evacuation of Great

\footnotetext{
${ }^{327}$ Oral history of Roy Leadbeater by Eugene Rogan Roy Leadbeater Papers GB165 - 0412 (MECA), 36.
} 
Britain and by the summer of 1948 all of the Empire's agents had been recalled. This chapter has argued that the rise of Jewish nationalist groups along with the events of the World War Two created a situation in Palestine that the police could only combat, but not control. Despite the changes in training and increased understanding of terrorist groups, the tide of nationalist sentiment and violence in the Mandate proved too much for the Palestine Police and the British Empire to weather. 


\section{Conclusion}

Ultimately, colonial policing in both Ireland and Palestine can only be seen as a failure. There are a multitude of factors that led to the British Empire's exit from both theatres, many of which have been explained here. Still, the RIC, the Black and Tans, the Auxiliaries, the British Gendarmerie, and the Palestine Police were, in the end, unable to subdue largely uncooperative populations. The forces of nationalism and religion proved too great.

Yet out of this failure we are able to see an evolution of training and tactics out of the desire to make peace and maintain to the imperial status quo. The events of the Anglo-Irish War and the tactics often used by the security forces were without question, brutal. But these were military men who knew little more than war. They were not prepared or adequately trained to be policemen. When they came under attack from Irish nationalists they resorted more to their military training than to their police training; when the enemy attacked, they counterattacked. This certainly does not excuse the actions taken by the Black and Tans and Auxiliaries, but it does help to explain contributing factors to the bloodshed.

When the security forces of Ireland moved into the Palestine Mandate to form the British Gendarmerie, their training was little better than what they had received previously. However, they had several years of experience at that point and perhaps more importantly, were initially faced with a less hostile population to police. The Arabs and Jews of the Mandate did not seek and destroy constables in the same way that the IRA had. With this new environment, the violent streak of the Black and Tans did not manifest itself. What followed was the most peaceful years of the Palestine Mandate. 
The halcyon days of the mid to late 1920s meant that the training of security forces, for the most part, did not need to be revised. It was only after the 1929 Massacres that the glaring inadequacies of the Palestine Police were shown. The following decade saw a continuous cycle of riot and reform whereby the force was made much more effective and efficient. The training and tactics of the police now prepared constables to communicate with the population they policed and allowed them to resolve many situations peacefully.

The Arab Revolt 1936-1939 saw the rise of both Arab and Jewish terrorism. It was at this point that the seeds of the Palestine Police's failure were sown. With the aid of the military and the force's evolved tactics, the Palestine Police were able to maintain relative control of the Mandate until the beginning of the Second World War. It was at this point that Arab terrorism dissipated and Jewish terrorism grew. Throughout the war and during its aftermath the force tried to combat an unending barrage of attacks on Arab, Jewish, British non-combatants. The Jewish nationalists made it clear that they saw the British as an unwelcome occupying force. The Palestine Police wrestled for years with a question that we have yet to answer; how does one police terror? They were unable to answer this question and again, the forces of nationalism forced the British out. As it has already been said, the efforts of British Colonial policing in Ireland and Palestine were ultimately a failure. There were countless successes along the path to that failure, but in the end they were simply not enough. The rising tide of nationalism consumed these countries. Perhaps Douglas Duff said it best in reflecting upon his time after having left Palestine: "The pity of it all...each has so much of right and of justice on his side — and yet each has marred his cause by so deep a blot of black, bitter injustice and of bloodstained intolerance. $^{328}$

${ }^{328}$ Douglas V. Duff, Palestine Unveiled, (London: Blackie \& Son Limited, 1938). 


\section{Bibliography}

\section{$\underline{\text { Primary Sources }}$}

Newspapers

Advocate

The Catholic World

The Liverpool Echo

The Liverpool Post

The New Republic

The Nation

Palestine Gazette

The Times

\section{$\underline{\text { Memoirs }}$}

Binsley, Jack. Palestine Police Service. Montreaux: Minerva Press, 1996.

Duff, Douglas V. On Swallowing the Anchor. (London: John Long Limited, 1954).

Douglas V. Duff. Palestine Unveiled. (London: Blackie \& Son Limited, 1938).

Duff, Douglas V. Sword for Hire: The Saga of a Modern Free Companion. (London: John Murray, 1934).

Duff, Douglas V. The Rough With the Smooth, London: J.M. Dent \& Sons LTD., 1940.

Farran, Roy. Winged Dagger: Adventures on Special Service. London: Collins ClearType Press, 1948.

Fennell, Thomas. The Royal Irish Constabulary: A History and Personal Memoir. University College of Dublin Press: Dublin, 2003.

Wilkins, Penelope. Letters Home: From Leslie Herbert (Tom) Eddison D.F.C. To His Family at Yamba, Cotter Road, Federal Capital Territory, Australia. (Campbell: Penelope Wilkins, 2001).

\section{$\underline{\text { Parliamentary Debates (Hansard) }}$}

House of Commons

House of Lords 
Private Papers St. Antony's College, Oxford, Middle East Center Archives (MECA)

Caffretta Papers

Cannings Papers

Edwards Papers

Faraday Papers

Foster-Turner Papers

Kirby Papers

Leadbeater Papers

McNeil Papers

Monckton Papers

Poole Papers

Rice Papers

Sykes Papers

Scott Papers

Tegart Papers

Published Papers from St. Antony's College, Oxford, Middle East Center Archive

British Palestine Police Association Magazine.

Palestine Police Old Comrades Association.

United National Special Committee on Palestine.

\section{Oral Histories}

Brewer, John D. The Royal Irish Constabulary: An Oral History. Antrim, W.G. Baird, Ltd., 1990.

Youtube. "An Irish American Oral History," Youtube last modified on Jan 4, 2011. Accessed November 23, 2014. https://www.youtube.com/watch?v=NBxuJcxB15o

Youtube. "Tom Barry talk on Guerilla Warfare - Part 2," Youtube last modified July 11, 2013. Accessed November 21, 2014. https://www.youtube.com/watch?v=2508MkLxBWc 
$\underline{\text { Other }}$

Anglo-Irish Treaty - 6 Deember 1921. The National Archives of Ireland last updated 2002. http://treaty.nationalarchives.ie/document-gallery/anglo-irish-treaty-6december-1921/ (accessed December 17, 2015).

Bard, Mitchell. "Pre-State Israel: The Hussein-McMahon Correspondence." http://www.jewishvirtuallibrary.org/jsource/History/hussmac.html. (accessed on December 12, 2015).

Bill to amend provision for Government of Ireland [as amended in Committee, and on Consideration] (Enhanced British Parliamentary Papers On Ireland) http://www.dippam.ac.uk/eppi/documents/18825/page/506444

Bureau of Military History, Statement by Witness. By J.J. McConnell, W.S. 509, http://www.bureauofmilitaryhistory.ie/reels/bmh/BMH.WS0509.pdf (accessed March 1, 2015)

Defense of the Realm Act 1914 (First World War) http://www.nationalarchives.gov.uk/pathways/firstworldwar/first_world_war/p_d efence.htm

Dowbiggin, H.L. The Dowbiggin Report. London:Wyman and Sons, Ltd., 1930.

The Hope Simpson Report "British Palestine Mandate: The Hope-Simpson Report." http://www.jewishvirtuallibrary.org/jsource/History/hope.html (accessed on February 12, 2015).

Sykes-Picot Agreement. BYU WWI Document Archive. "http://wwi.lib.byu.edu/index.php/Sykes-Picot_Agreement (accessed December $17,2015)$

The Balfour Declaration. Israel Ministry of Foreign Affairs last updated 2013. http://www.mfa.gov.il/mfa/foreignpolicy/peace/guide/pages/the $\% 20$ balfour $\% 20 \mathrm{~d}$ eclaration.aspx (accessed December 20, 2015).

Treaty of Lausanne, BYU WWI Document Archive last updated 2009. http://wwi.lib.byu.edu/index.php/Treaty_of_Lausanne (accessed on December 17, 2015).

Union with Ireland Act 1800 (Union with Ireland Act 1800) http://www.legislation.gov.uk/apgb/Geo3/39-40/67/contents

The Letters and Papers of Chaim Weizmann: Volume VII, Series A, August 1914November 1917. Meyer W. Weisgal, Gen. Ed. (Jerusalem: Israel University Press, 1975)

The Letters and Papers of Chaim Weizmann: Volume IX, Series A, October 1918-July 1920. Meyer W. Weisgal, Gen. Ed. (Jerusalem: Israel University Press, 1977) 
The Letters and Papers of Chaim Weizmann: Volume XIV, Series A, July 1929-October 1930. Barnet Litvinoff, Gen. Ed. (Jerusalem: Israel University Press, 1978)

The Letters and Papers of Chaim Weizmann: Volume XVII, Series A, August 1935December 1936. Barnet Litvinoff, Gen. Ed. (Jerusalem: Israel University Press, 1979)

\section{$\underline{\text { Secondary Sources }}$}

Bebbington, D.W., The Mind of Gladstone: Religion, Homer, and Politics. Oxford: Oxford University Press, 2004.

Bennett, Richard. The Black and Tans. London: Edward Hulton, 1959.

Buckley, Maureen. "Irish Easter Rising of 1916." Social Science, Vol. 31, No. 1 (January, 1956): 49-55.

Brewer, John D. The Royal Irish Constabulary: An Oral History. Antrim: W.G. Baird, Ltd., 1990.

“British Mandate Over Palestine," Global Perspectives, last modified 2002. http://www.cotf.edu/earthinfo/meast/israel/IPtopic2.html.

Cottrell, Peter, Brendan O'Shea, and Gerry White. The War for Ireland: 1913-1923 Oxford: Osprey Publishing Ltd., 2009.

Cottrell, Peter. The Anglo-Irish War: The Trouble of 1913-1922. Oxford: Osprey Publishing Ltd., 2006.

Enright, Sean. Easter Rising 1916: The Trials. Kildare: Merrion, 2014

Escouflaire, R.C. Ireland: An Enemy of the Allies? Translated by R.C. Escouflaire. New York: E.P. Dutton \& Company, 1920

Fedorowich, Kent. 'The Problems of Disbandment: The Royal Irish Constabulary and Imperial Migration'. In Irish Historical Studies, vol. 30, 1996.

Galnoor, Itzhak. The Partition of Palestine: Decision Crossroads in the Zionist Movement. New York: University of New York Press, 1995.

Gannon, Sean William. "The Formation, Composition, and Conduct of the British Section of the Palestine Gendarmerie, 1922-1926," in The Historical Journal, 56, pp977-1006

Gannon, Sean William. “Sure It's Only A Holiday...':The Irish Contingent of the British (Palestine) Gendarmerie, 1922-1926" in Australasian Journal of Irish Studies 13 (2003), pp. 64-85.

Hart, Peter. The I.R.A. and Its Enemies: Violence and Community in Cork, 1916-1923. Oxford: Oxford University Press, 1999 
Hachey, Thomas E. Britain and Irish Separatism: From the Fenians to the Free State 1867/1922. Chicago: Rand McNally College Publishing, 1977.

Henry, William. Blood for Blood: The Black and Tan War in Galway. Cork: Mercer Press, 2012.

Hittle, J.B.E. Michael Collins and the Anglo-Irish War: Britain's Counterinsurgency Failure. Lincoln: Potomac Books Inc., 2011

Horne, Edward. A Job Well Done: Being a History of the Palestine Police Force 19201948. Sussex:The Book Guild: Sussex, 1982)

"Irish Soldiers in the First World War," Department of the Taoisearch last modified 2013, accessed December 17, 2015 http://www.taoiseach.gov.ie/eng/Historical_Information/1916_Commemorations/ Irish_Soldiers_in_the_First_World_War.html

James, Malcolm. Born of the Desert: With the SAS in North Africa. London, Greenhill Press, 1945.

Jeffery, Keith. The British Army and the Crisis of Empire, 1918-1922. Manchester: Manchester University Press, 1984.

Jeffries, Charles. The Colonial Police. London: M. Parrish, 1952.

Kenny, Kevin. Ireland and the British Empire. Oxford, Oxford University Press, 2004.

Leeson, D.M. The Black and Tans: British Police and Auxiliaries in the Irish War of Independence, 1920-1921. Oxford: Oxford University Press, 2011.

Foster, R.F. Modern Ireland 1600-1972, New York: Penguin Books, 1988

Reynold, Nick. Britain's Unfulfilled Mandate for Palestine. London: Lexington Books, 2014.

Segev, Tom. One Palestine, Complete: Jews and Arabs Under the British Mandate. Translated by Haim Watzman. New York: Metropolitan Books, 1999.

Shepherd, Naomi. Ploughing Sand: British Rule in Palestine, 1917-1948. New Brunswick: Rutgers University Press, 1999.

Sinclair, Georgina. At the End of the Line: Colonial Policing and the Imperial Endgame 1945-1980. Manchester: Manchester University Press, 2006.

Sinclair, Georgina. "Get into a Crack Force and Earn 20 a Month and all found...': The Influence of the Palestine Police upon Colonial Policing 1922-1948." In European Review of History Vol. 13, No. 1 March 2006, pp. 49-65

Smith, Jeremy. Britain and Ireland: From Home Rule to Independence, Harlow: Longman, 1999.

Sykes, Christopher. Crossroads to Israel: 1917-1945. Bloomington: Indiana University Press, 1965. 
“The Black and Tans," BBC last modified September 24, 2014, accessed on November 19, 2014. http://www.bbc.co.uk/history/british/easterrising/aftermath/af05.shtml

"The Black and Tans - who were they?" War of Independence last modified in 2011, accessed on November 22, 2014, http://www.warofindependence.info/?page_id=505 